\title{
CATORCE CARTAS DE FEIJOO AL P. SARMIENTO
}

\author{
P R E S E N T A C I O N
}

Habent sua fata libelli. Este viejo proverbio latino podria muy bien aplicarse a las catorce cartas -once de ellas autógrafas- del P. Feijoo, que ahora ofrecemos a la luz pública.

Fueron dadas a conocer en 1934 por G. Marañón ${ }^{1}$. Según dicho autor, «las halló casualmente» el P. Mauro Gómez Pereira, abad de Samos (193072), (y muy lejos de Galicia» ${ }^{2}$.

El propio Marañón las utilizó casi todas, en mayor o menor medida, en varios capítulos de su obra Las ideas biológicas del P. Feijoo, especialmente en el capítulo XIV dedicado a las relaciones entre Feijoo y Sarmiento ${ }^{3}$.

Ello quiere decir que no aparecen juntas ni íntegras, salvo tres de ellas, ni en plan sistemático, sino esparcidas por distintos apartados - a veces en trozos sueltos una misma carta-; en nota muchas veces y sin relieve es-

1 G. Marañón, Las ideas biológicas del P. Feijoo, Madrid 1934, 140, nota 1. Nuestras citas se referirán siempre a esta primera edición.

2 ID., ibid., 140, nota 1.

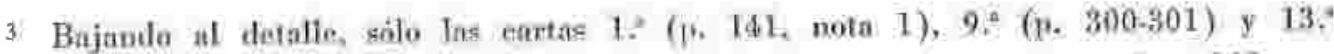
(p. 138, nota 1) estủn prî́cticamente reproducidas; de la 4.4 ( ta 3) y 8.7 (pp. 61 y 301.302 ) aparece separado su contenido en kistintas páginas: la

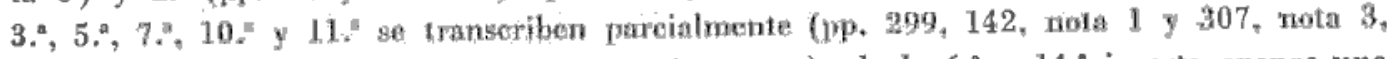

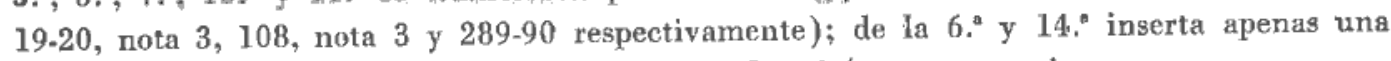
pequeña cita (pp. 142 y 37 , nota 2 ); la $2 .^{a}$ y la $12 .^{x}$ no se mencionan. 
pecial; y sin respetar sus caraeteristicas ortográficas, que dan a las cartas un peculiar sabor y encanto; aparte de los fallos que en su transcripción se advierten, por no haber utilizado el texto original sino su copia.

Por todo ello hanos parecido muy oportuno publicarlas todas juntas e integramente y en la forma sistemática que hoy se estila.

Por mucho tiempo se estuvo en la creencia de que habian perecido todas en el incendio que en 1951 asoló al monasterio de Samos. Sin embargo, últimamente, y también de un modo fortuito y casual, aparecieron un buen día, entre una serie de papeles muy heterogéneos, trece de las dieciséis cartas originales citadas por Marañón ${ }^{4}$; y, junto con ellas, la copia de las dieciséis, hecha por el archivero de entonces, P. Plácido Arias, para ser utilizada por el Dr. Marañón en su aludida obra ${ }^{5}$.

Las cartas que llevan los números 2, 11 y 12 son copia de las originales. Son éstas, sin duda, las que se hallaban en la celda llamada del P. Feijoo, sita en el ángulo oriental del segundo piso del claustro grande, en la cual ardieron junto con la librería particular del P. Maestro y otros enseres que allí se guardahan.

Con su publicación nos proponemos contribuir a un mayor conocimiento de esas dos grandse figuras que fueron Feijoo y Sarmiento; y queremos aprovechar esta oportunidad para formular nuestro ruego a quienes posean más cartas de estos dos sabios benedictinos, que se decidan también a publicarlas en beneficio de la cultura.

Hasta el presente es muy egcasa, por no decir easi nula, la correspondencia epistolar publicada de estos dos hermanos de hábito ${ }^{6} ;$ a pesar de que, por testimonio del propio P. Sarmiento, sabemos que fue muy extensa. Dice asi en su Autobiografia: a1728.-Quiso el Rvdmo. Feixoo que yo corrigicse sus tomos: asi lo hice hasta su muerte, y formé 14 índices de a dos pliegos (28 pliegos). Con esta ocasión mantuve correspondencia epis-

4 Dos de estas dieciséis cartas feijonianas van dirigidas al P. Vallejo, de quien hablaremos más adelante, las cuales pondremos en apéndice.

5 Que Marañón utilizó en su libro las cartas según esta copia y no las originales, lo deducimos por el hecho de que transcribe los mismos fallos que advertimos en dichas copias.

6 Ha editado cuatro cartas dirigidas por Feijoo a Sarmienta - comprendidas entre los años 1736-1749 - Sor Guadalupe de LA Novix, Cuatro cartas autógrafas del P. Feijoo al P. Martín Sarmiento: Yermo 2 (1964) 259-65. 
tolar, y por el cajón en que conservo sus cartas, se conocerá cuántos pliegos le habré escrito yo en mis cartas por tantos años» ${ }^{7}$.

Estas catorce cartas que hoy presentamos fueron escritas entre los años 1729 y 1749 , o sea, durante el tiempo en que salieron a luz los tomos del Teatro Crítico, a partir del tercero, hasta la publicación del tercer tomo de Cartas Eruditas. Salta, pues, a la vista que significan una porción mínima en comparación con las que debió de escribir a su «amiga i señor» Fr. Martin Sarmiento.

Aparte de otros aspectos que pudieran señalarse, dos notas sobresalen principalmente en estas cartas. Por un lado la íntima amistad que ligaba a estos los grandes hombres de ciencia y hermanos de bábito; amistad pue, por lo demás, nos era ya conocida a través de otras fuentes: baste recordar, por ejemplo, por parte del monje de San Martín de Madrid su h Aprobaciónn de la llustración apologética al primero y segundo tomo del Theatro Crítico y, como consectuencia de la misma, los dos tomos de Demonstracton crítico-apologética de el Theatro Crítico Universal (Madrid, 1732); y, por parte del monje de Samos, el elogio tan cumplido que de Sarmiento hace (sin nombrarlo) en el tomo IV, discurso XIII, n." 84 del Theatro y en el «Prólogo al lectorn del tomo $\mathrm{V}$, en donte le llama wmi intimo amigos. Pow otro lado, y sobre todo, se destaca el importantísimo papel que desempeñó el P. Sarmiento en la gestación y en la edición de las obras feijonianas. Téngase en cuenta que tanto el Theatro como las Cartas no se imprimieron en Oviedo sino en Madrid. El P. Sarmiento, hijo profeso de San Martín de Madrid, en donde residía, fue el instrumento providencial de que se valió Treijoo para llevar a caho la publicación de sus escritos: a él enviaba los originales manuscritos de sus diseursos y de sus cartas; y él cuidaba de aeoplarlos en los distintos volúmenes, de someterlos a la censura, de mandarlos a la imprenta, de eorregir las pruebas, aparte de que él era también quien le proporcionaba los libros, los datos y la bibliografía que no encontraba en Oviedo.

Todo esto se verá confirmado en el sucinto comentario que pasamos a hacer de cada una de las catorce cartas de nuestro monje benedictino. Y tratándose de cartas tan personales entre dos amigos, hermanos de hábito, originarios de una misma región entrañable, Galicia, veremos también có-

7 Publicada por J. Domíncuez Fontela, Fr. Martin Sarmiento. Su autobiografiu: Boletín arqueológico de la Comisión Provincial de Monumentos históricos y artísticos de Orense 7 (1924-26) 153-172. 
mo en ellas encuentran eco esas impresiones espontáneas, ingenuas y a veces un tanto cáusticas, suscitadas por los sucesos más o menos intrascen. dentes que suelen constituir la trama normal del diario vivir: comentarios de sucesos a veces tristes, cuales son la muerte de algún familiar o amigo (cartas 5 y 6), a veces alegres, por ejemplo cuando alude al comportamiento del general de la congregación de Valladolid con el monasterio de Samos (carta 12), o a la elección como secretario de Estado del cardenal Gonzaga (carta 7), o al nuevo invento para hacer más útiles las minas (carta 11); expresiones de buen humor, en las que abunda la carta 7 , bromeando con el "vejestorio Feijoo» y con su amigo y hermano de San Martín de Madrid, que «no piensa sino en meterse en su rincón y cerrarse en su zelda hallándose en una edad floreciente», o la alusión irónica al casamiento de Mayáns (carta 9), o al testamento de un usurero (carta 13); alusión a intrigas o ciertas ambicioncillas entre miembros de la congregación. vallisoletana a que ambos pertenecen (cartas 5, 7, 12 y 14); expresiones absolutamente propias del género epistolar familiar: “reverendísimo rabón» (carta 7), “la carabina de Ambrosio» (carta 7), “el demonio del judiazo» (carta 8), “Y con esto dejo la pluma i me voi a la chiminea) (carta 10), etc., etc.

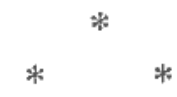

1." - Carta fechada el 30 de abril de 1729. El P. Feijoo había publicado los dos primeros tomos del Theatro y el tercero contaba, desde el 20 y 23 de diciembre de 1728 , con la aprobación de la congregación y idel obispado de Oviedo respectivamente. En cambio, la aprobación del P. Joaquin de Ania, ex-general de la congregación de San Bernardo, por orden deI canónigo de Alcalá de Henares y vicario de la villa de Madrid, D. Francisco Lozano, no se firmó hasta el 24 de abril de 1729.

Este retraso de la aprobación del P. Ania fue motivado, sin duda alguna, por lo que apunta esta carta que comentamos.

$\mathrm{Y}$ es curioso advertir que la carta está fechada con posterioridad a la aprobación del P. Ania. Lo cual nos induce a pensar que el propio Sarmiento, conocedor del "alboroto» de los capuchinos, corrigió por su cuenta, antes de llegarle el aviso del P. Maestro, lo pertinente al asunto, apoyarlo en las facultades que le había dado de corregir sus escritos, según ruatifiesta en su autobiografía ${ }^{B}$. Marañón no advirtió este detalle de am-

8 Cfr. nota anterior y el texto correspondiente. 
bas fechas, el cual juzgamos importante en el sentido de que nos viene a confirmar la confianza que Feijoo había depositado en Sarmiento y la íntima compenetración entre ambos.

No se especifica lo que Feijoo decía del P. Carabantes. Creemos que debió de ser lo que en el discurso sexto del tomo III del Teatro Crítico, párrafo II, n. ${ }^{\circ} 7$, escribe sobre Milagros supuestos:

"No ha muchos siglos que en cierta provincia de la christiandad predicaba un venerable varón y de espiritu verdaderamente apostólico; pero de quien en vidin no se decía cosa especial acerca de profecías y milagros. Luego que murió aquel santo hombre, uno de los que havían assistido a sus missiones dio a la estampa su vida llena de predicciones y prodigios, sin más examen auténtico que el que bastó a satisfacer su piedad poco ordenada; y lo que es más, circunstanciando los sucessos con la designación de los lugares y personas. Qualquiera que en los siglos venideros leyera aquellas actas, considerando que el autor fue coetáneo de este hombre venerahle y que escribió dentro de la misma provincia que fue theatro de su predicación, no dudará darlas entero crédito. ¿Quién pensará que huvo audacia en un escrito para referir innumerables prodigios delante de millares de testigos que podían darle o con la falsedad o con la incertidumbre en los ojos? Sin embargo, él lo hizo o por el afecto ciego que profesaba a aquel varón apostólico o por dexar su nombre en el mundos? ${ }^{9}$.

Es decir, que el P. Sarmiento suprimiría del anterior párrafo toda indicación local y personal, con lo que se dieron por satisfechos los capuchinos y el P. Ania, libre ya de externas presiones, pudo dar su aprobación.

El autor, al que alude Feijoo, de la vida del P. Carabantes debió de ser un tal Diego González de Quiroga: «El nuevo Apóstol de Galicia el P. Carabantes... Su vida, virtudes, predicación y prodigios) (Madrid, 1698).

El P. José de Carabantes, «un venerable varón de espíritu verdaderamente apostólico", nació en la villa de Carabantes (Soria) en 1628 y murió en 1694 en Monforte de Lemos (Lugo). Profesó en la orden capuchina y fue un misionero incansable. Predicó primeramente en Venezuela, dedicando su celo principalmente a los indios caribes. Vuelto a su patria, recorrió varias regiones españolas, tales como Andalucía, Extremadura y Galicia, diócesis de Astorga, León, Oviedo, Burgos, Navarra y Toledo. Los últimos años de su vida los pasó en Monforte de Lemos en calidad de confesor de doña Catalina Sandoval y de la Cerda, esposa del famoso VII conde de Lemos, D. Pedro de Castro, y, después de la muerte de éste, monja profesa

9. J. FerJoo, Theatro Critico Universal, t. HI, p. 122 (ed. 1781), 
del convento de clarisas de Monforte, fundación de los mismos condes. Fue enterrado en la iglesia de las clarisas y se dice que su cuerpo se conserva incorrupto. Escribió varias obras de predicación y sobre el modo de aprender el idioma de los indios ${ }^{10}$.

$2 .^{\mathrm{a}}$ - 22 de mayo de 1732. Copia. El original de esta carta diebió de hallarse en la celda del P. Feijoo, en donde ardió en el incendio de 1951. Es de carácter estrictamente privado y familiar. Alude en ella el P. Maestro a un asunto de capellanía relacionado con el monasterio de Montserrat, de Madrid.

Se refiene, al final de la carta, a una nueva impresión de su Ilustración apologética al primero y segundo tomo del Theatro Crítico: creemos se trata de la tercera impresión, aparecida en Madrid, por los heredıros de Francisco del Hierro, año 1734. Y anuncia a su corresponsal que por correo le envía un nuevo discurso para que lo incluya en el Theatro, posiblemente en el tomo V, aparecido en 1733; un dato más por el que sabemos que el P. Sarmiento intervenía incluso en la distribución de los distintos discursos que integraban cada tomo.

$3 .^{n}$ - Oviedo, 14 de junio de 1732. Es una carta curioga. Feijoo se encontraba ya en los 56 años de edad. Su vista, fatigada por prolongadas leoturas, no le permitía leer con la nitidez que él quisiera, especialmente la letra menuda. El mismo se habia comprado por 240 reales una lupa -él la llama simplemente vidro-; pero le resultó inútil. Más tarde compró otra a un francés, que tampoco le satisfizo; de ahí que acuda a su amigo Sarmiento para que le busque «uno de estos vidros» sin reparar en el precio, con tal de que sea bueno. Años más tarde le pedirá también unas gafas de présbita ${ }^{11}$.

A continuación le comunica que de Pontevedra le habían escrito que un sobrino suyo - de Sarmiento- quería hacerse monje de Samos y que él _-Feijoo- aunque ya había recibido palabra del abad de Samos de que podía hacer lo propio con un muchacho de Asturias, pariente suyo, (la conmuté a favor de esotro» - del sobrino del P. Sarmiento-. ¿Gesto realmente fino y delicado de un verdadero amigo!

10 Enciclopedia Universal Ilustrada Europeo-Americana, art. Carabantes (José de), t. II, p. 625 .

11 Cfr. carta 14. 
El sobrino de Sarmiento en cuestión creemos que sería aquel a quien él llama fray Millán en su Vuage a Galicia en 1754: '(Pagan renta a este priorato de Chouzán, que hoy administra fray Millán, mi sobrino, hijo de Samos) ${ }^{12}$.

En el margen de la earta anuncia a su corresponsal que dos personas amigas pondrán en sus manas — sin duda para que él los remita a Oviedo- un poco de tabaco para el regente del colegio de San Vicente y dos resmas de papel para el propio Fieijoo. Sobre el envío de tabaco habla también en las cartas 4 y 5 . Por la carta XXVII del tomo primero de Cartas Eruditas vemos que el P. Feijoo era un buen gustador dol tabaco. En ella expone sus experiencias sobre la manera de conservarlo para que no pierda su sabor y aroma.

4." - Oviedo, 9 de enero de 1733. Contesta a una carta del P. Sarmiento en que le hablaba del «corto número de discursos», por lo cual resultaba demasiado achicado el tomo que preparaba para dar a la imprenta. Probablemente se trataba del tomo $\mathrm{V}$ del Theatro, cuya dedicatoria va firmada el 4 de marzo de 1733.

Por ella vemos cómo una de las consignas entre ambos corresponsales era la de que Sarmiento acoplaría los discursos de modo que los tomos apareciesen bastante uniformes en grosor. Cosa, por lo demás, no muy difícil, ya que los discursos no solían guardar entre si estrecha relación y era indiferente insertarlos en uno $u$ otro volumen.

El discurso sobre la poesía, a que alude al comienzo, que «ha de salir larguísimo", creemos que debió de quedarse en mero propósito. No figura en los siguientes tomos del Teatro. Tan sólo la carta XIX del tomo V de Cartas Eruditas está dedicada a este tema. Responde en ella a un corresponsal que se interesaba por la cita de Marcial como favorable a la tesis que había formulado en el tomo IV del Theatro Crítico «de preferir o a lo menos igualar nuestro poeta Lucano al gran Virgilio). No creemos, sin embargo, se trate del que alude en esta carta que comentamos; pues abarca apenas cinco hojas.

Pide a continuación a su amigo le compre el Ars Magna de Raimundo

12. M. Samminno, Viaje a Galicia de fray...-. Edición y notas de E. J. Sánchez Cantón y J. M. Pita Andrade: Cuadernos de Estudios Gallegos, Anejo III. Santiago de Compostela 1950, pp, 15-16. 
Lulio y la obra Ars memoriae vindicata de Brancaccio ${ }^{13}$. También en esta ocasión las gestiones del P. Sarmiento en Madrid fueron eficaces. Del Ars memoriae vindicata se ocupa Feijoo en la carta XXI del tomo primero de Cartas Eruditas. La carta XXII del mismo tomo está dedicada por entero al Arte Magna de R. Lulio; y vuelve a ocuparse de ella en la carta XIII del tomo segundo y en la XXIX del tomo tercero ${ }^{14}$.

A fuer de agradecido y en un tono muy llano y familiar anuncia a su amigo, al final de esta carta, que le envía por un propio «52 varas de lienzo asturiano (que dura tres tanto tiempo más que el de Galiçia)" para que tanto él como el P. Visitador «se hagan cada uno cuatro camisas y otros tantos pares de calzoncillos». Notemos, con Marañón, «la libertad de lenguaje que impera en estas cartas privadas, escritas de prisa y, como puede comprobarse en los originales, jamás corregidas. Buena prueba este "tres tanto tiempo», por “tres veces más» ${ }^{15}$.

Del P. Visitador, aquí mencionado ${ }^{16}$, vuelve a hablar al P. Vallejo en carta fechada el 28 ide agosto de 1734; de la cual se desprende que era quien corría a cargo de la encuadernación de sus libros y de otros asuntos administrativos; pero por estas fechas «se ha exonerado de ella por la razón o sin razón que no ignorarás»; por lo que encarga de ello al mismo P. Vallejo ${ }^{17}$.

$5 .^{\mathrm{a}}$ - Oviedo, 31 de mayo de 1738. No se expresa el destinatario; pero todas las circunstancias concurren a inducirnos a creer que no es otro que el P. Sarmienio. Carta de carácter eminentemente privado y familiar. Habla en el primer párrafo de un asunto interno concerniente a la congregación vallisoletana, posiblemente de conferir algún cargo a determina-

13 En la copia que de esta carta se envió a Marañón se lee, en efecto, Bramacho; y así lo transcribió aquél el la nota $2 .^{a}$ de la p. 141 de Las ideas biológicas del P. Feijoo; sin embargo, en el original es clara la lectura de Brancacho.

14 Acerca del antilulismo de Feijoo véase G. M. Colombas, Feijoo y el lulismo: Estudios Lulianos 7 (1963) 113-130. Véase también T. y J. Carreras Artau, Feijoo y las polémicas lulianas en el siglo XVIII, en "Historia de la filosofía española. Filosofía cristiana de los siglos XIII al XVm, t. 2., Madrid 1943, pp. 357-76; J. Carreras Artau, La postura antiluliana del P. Feijoo, en "Cuadernos de la cátedra Feijoo», n. 18, 4ol. II, Oviedo 1956, pp. 277-284.

15 G. Marañón, o. c., 142, nota 3.

16 Véase la nota que ponemos al texto de la carta 4.

17 Véase la carta $1 .^{a}$ del Apéndice. 
dos sujetos. Si conociésemos la carta de su corresponsal, a la que ésta se refiere, podríamos aclarar más el asunto.

De mayor interés es el párrafo final de la misma, por el que se demuestra con toda claridad el temperamento extraordinariamente limosnero del P. Feijoo. Dice él que no era la virtud sino el genio quien le impulsaba a ello; pero añade a renglón seguido: “ ¿No será bueno asegurarme?» Es decir, que, en el fondo, era la virtud la que le movía; pues no ignoraba que «la limosna, en frase de la sagrada Escritura, libra de la muerte y limpia de todo pecado) (Tob 12, 9).

El P. Nóboa, en la oración fúnebre que pronunció en la iglesia samonense con motivo de las exequias celebradas por los monjes en sufragio del hijo más preclaro de Samos, alude por tres veces a lesta virtud de Feijoo: "Los experimentan sin movimiento aquellas manos, que eran el instrumento de el alivio de su miserian; "Repartía a los pobres quanto emolumento temporal llegaba a sus manos. Mucho repartió su caridad a los mendigos y necesitados públicos, sin lo que distribuía sin que lo supiesse más que la mano que era instrumento de su piedad»; “El producto de sus obras literarias... fue dividido entre Dios y sus pobres: lo que no entró en el poder de éstos, lo consagró a Dios sobre esse altar a cuyos pies postrado havía hecho el solemne sacrificio de su professión” ${ }^{18}$.

Otro panegirista suyo, el P. Uría, apunta el dato curioso de un pobre "a quien socorría todos los días de su messa», el cual, decía Feijoo, klo havía de llevar al cielo de la manos ${ }^{19}$.

Por su parte el Dr. Alonso Francos Arango contaha que «en los años de $[17] 41$ y [17]42, muy estériles en este país, empleó en granos grande suma de caudal para que infinitos pobres tuviessen que comer y para que les quedasse también para sembrar, para cuyo piadoso y santo fin tenía empleadas varias personas no sólo en esta ciudad sino en muchas aldeas; y porque de noche por la olausura no podía salir a dar limosna, pero co-

18 E. Nóbоa, Oración fúnebre en las exequias que en 22 de enero de 1765 celebró el real monasterio de San Julián de Samos a su hijo el muy ilustre señor y reverendíssimo padre nuestro fray Benito Feijoo. Madrid 1765, pp. 4: y 46.

19. B. UníA, Oración fúnebre que en las solemnes exequias celebradas a la buera memoria de el illustríssimo y reverendissima don fray Benito Gerónymo Feijoó en el colegio de San Vicente de Oviedo, dia 17 de diciembre de 1764, dixo el P. Maestro Fr. Salamanca 1765 , p. 25 , 
mo los pobres ya le conocían, iban a clamar bajo su celda, y les arrojaba prontamente por las ventanas, embueltos en papeles, reales y pesetas) ${ }^{20}$.

En una larga postdata vuelve a hablar del tabaco, ique, por lo visto, tenía también sus aficionados en el colegio de San Vicente de Oviedo. Y al final de la misma pide a Sarmiento le compre los tres tomos de moral del P. Gobat ${ }^{21}$ y la Explication... des cérémonies de l'Eglise del benedictino francés Claudio de Vert ${ }^{22}$.

6." - Oviedo, 27 de junio de 1739. Ruega al P. Sarmiento se informe acerca de un tal Fr. Marcos Rubiños, mercedario de un convento de Madrid, el cual le había eserito contradiciéndole en lo que dice en el tomo VIII, discurso 6., nn. 116 y 117 del Theatro. Feijoo afirma aquí que los exorcismos sólo tienen por objeto a los energúmenos: «aquéllos, digo, que se fulminan contra los demonios obsidentes o possidentes de los cuerpor humanos). Por lo tanto (contra todas las incomodidades del hombre, distintas de demonios obsidentes o possidentes, se debe proceder no con exorcismos sino con preces». Contra esta doctrina le envió el fraile mercedario objeciones "por la mayor parte ineptas), dice Feijoo. Contesta a su carta -que inserta- en los números $137-201$ del mismo discurso y volumen.

Pasa luego a pedir a su amigo y corresponsal le busque textos de los

20 A. Francos Arango, Oración fúnebre que en las solemnes exequias que la universidad de Oviedo consagró en el día 27 de noviembre de este año te 1764 a la inmortal memoria del ilustríssimo y reverendissimo señor don fray Benito Gerónimo Feijoó y Montenegro..., dixo el señor doctor don - . Oviedo 1765, pp. 24-25.

21 E1 P. Jorge Gobat (1600-1679) fue uno de los más insignes moralistas del siglo XVII. Perteneció a la Compañia de Jesús y en el transcurso de sı̣̆ larga vida escribió 14 tratados de moral, los cualeg fueron reunidos en tres grandes vols., el primerch en vida del propio P. Gobat, en 1678, y los dos últimos en 1681. Una nueva edición se publicó en Doutai en 1700; ésta es, probablemente, la que aquí pide Feijoo. Algunos de sus escritos fueron censurados por el obispo de Arras en 1703, lo cual provocó una viva polémica. Sin embargo, ealvo ciertos puntos secundarios, su doctrina es sólida y segura (Cfr. A. Vacant, Gobat, Georges, en "Dictionnaire de théologie catholique», t. XII, col. 1469-70).

22 El P. Claudio de Vert (1645-1708) fue monje benedictino perteneciente a la congregación cluniacense, en la que ejerció importantes cargos: tesorero de la abadía de Cluny, visitador de la congregación, vicario general y prior de San Pedro de Abbaville. Fue autor de varios libros; pero el que le dio más fama fue éste que pide Feijoo, de 4 tomos en $8 .^{\circ}$, aparecido por vez primera en 1706-13 (Cfr. M. Ziegelbaugr, Historia rei litterariae O.S.B., Augustae Vindelicorum 1754, III, pp. 439-40). 
santos padres y doctores que prueben que «la filosofía (o in wenere o la aristotélica) es inútil para explicar los misterios de la fe». Una prueba más de la eficaz intervención de Sarmiento en la gestación del Theatro y de las Cartas de Feijoo. En tal sentido merece leerse todo el capítulo XIV de Las ideas biológicas del P. Fieijoo, de Marañón, dedicado todo él a Sarmiento y a lo mucho que trabajó en la elaboración de los escritos feijonianos. Básase en buena medida en estas cartas que hoy publicamos integramente.

7." - Oviedo, 17 de septiembre de 1740. Se excusa de por qué no estaba dispuesto a aceptar cargos honoríficos. Sabemos que rehusó el ofrecimiento en 1725 de abad de San Martín de Madrid y de San Julián de Samos, su casa de profesión, así como de un obispado en América y, en 1737, de general de la congregación. Razón habida de la fecha de esta carta, tal vez sea el último de los ofrecimientos a que aquí se alude y a cuya aceptación le animaba su amigo Sarmiento desde Madrid. Como hombre inteligente sabía apreciar en su justa medida la vanidad de los honores humanos, “este vanísimo honor de reverendísimo rabón» [sic]. Alega, además, su edad de 64 años; pero, aunque aquí no lo dice, sabemos que el motivo principal de rehusar cargos públicos era porque le restaban tiempo para escribir sus obras ${ }^{23}$.

Hoy día la Iglesia dispensa de la ley del ayuno a los 60 años de edad. En tiempo de Feijoo no estaba claro este punto; de ahi la duda que manifiesta de si a sus 64 años estaba exento del precepto del ayuno. El cardenal Gonzaga, mencionado aquí por el P. Maestro, había sido nuncio en Éspaña desde 1736 hasta 1739. Benedicto XIV le nombró en 1740 secretario de Estado - suceso al que se refiere la carta que comentamos--; en cuyo cargo permaneció hasta su muerte, acaecida el 28 die agosto de 1756. En los días de su nunciatura en Madrid fue contertulio del P. Sarmiento, movido, sin duda, por su amor y afición a las letras y las artes. Fruto de las conversaciones entre ambos fueron los 50 pliegos de las Memorias para la historia de la poesía y poetas españoles, que el sabio

23 Leemos en un manuscrito del primer cuarto del s. XVIII: "Fue electo abad del monasterio de San Vizente de Oviedo. Renunció a la abadía después de haverla rrovernado cerca de dos años, por reconocer que el govierno le quitava algunas horas de pstuclio a que es muy aplieado" (M. Arias, Un abadologio inédito del monasterio de Samos: Arehivos Leoneses 22 (1968) 269). 
benedictino le dirigió en 1745 y que el monasterio de San Martín de Madrid publicó en 1775 .

Al final de la carta, en un momento de buen humor, se chancea con su amigo de que éste «no piense sino en meterse en su rincón... hallándose en una edad floreciente con buena salud», siendo así que "hacía mucha bulla porque el vejestorio Feijoo quiere vivir para sí lo poco que le resta vivir». Afortunadamente para las letras españolas, aun le quedaban 24, años de vida durante los cuales pudo escribir los cinco tomos de Cartas Eruditas.

8. ${ }^{\mathrm{a}}$ - Oviedo, 21 de octubre de 1741. Carta curiosísima, ampliamente comentada por el doctor Marañón, según el cual el microscopio de que habla aquí Feijoo fue "tal vez el primero que vino a España» ${ }^{24}$. A nuestro monje samonense no le prestó servicio, porque sus trabajos literarios no le permitían el lujo de poder estarse horas y horas de observación minuciosa. En cambio a Sarmiento le vino, sin duda, de perlas para sus estudios de historia natural o, cuando menos, para enriquecer su celdamuseo con otro objeto más entre los muchos de valor que ya atesoraba. Significaba, por otra parte, una muestra de gratitud y de fina delicadeza hacia su incondicional colaborador.

En otro apartado de su carta habla Feijoo de la necesidad que tiene de unos anteojos para su vista cansada. Explica cómo los primeros que usó, a los cinco años ya no le servían; y cómo los que al presente usa (caunque hoy me sirven, pero no tan bien». Mas, por el momento, no le da el encargo de comprar otros. Esto lo va a hacer en la siguiente carta de la que pasamos a ocuparnos.

9. ${ }^{\mathrm{n}}$ - Oviedo, 28 de octubre de 174.1. En la carta anterior hablaba de la necesidad que sentía de nuevos anteojos; pero al final de ella escribía: “Esto aun no corre tanta prisa que no podamos hablar más sobre la materia antes de pasar a la compra o al encargo». Ahora, apenas transcurridos siete días, le escribe confirmándole el encargo de que le compre nuevos anteojos. Pondera los fabricados por Campani en Roma, "los cuales se deben creer los mejores deI mundos. Les seguían en perfección, a su juicio, los provenientes de Venecia y luego, aunque muy inferiores, los de Alemania. 
Resulta interesante, desde el punto de vista de la óptica, la minuciosidad de detalles que le da con el fin de que acierte bien en la compra de los que mejor le convengan. Detalle curioso es su alusión a los que estaban guarnecidos de concha. En Samos existen dos tallas con estos anteojos de concha, una en las pechinas de la iglesia y la otra en el primer piso del claustro gótico. Ambas fueron, sin duda, observadas y contempladas por el P. Feijoo más de una vez.

Al margen de la carta alude con cierto aire despectivo al casamiento de Mayáns y Siscar, con quien, según Millares Carlo, no debió de mantener relaciones muy cordiales ${ }^{25}$.

$10 .^{2}$ - Oviedo, 6 de enero de 1742. Comienza la carta refiriéndose a las Memorias para la historia de la poesía y poetas españoles, que su corresponsal el P. Sarmiento estaba preparando a ruegos del cardenal Sixto Valenti Gonzaga, de quien hemos hablado al comentar la carta 7. Feijoo, que conocia a fondo las cualidades de su amigo, le expresa sus temores de que «salga muy larga y que por muy cargada de erudición sea pesada». Sarmiento era hombre de una erudición asombrosa; pero sus escritos distan mucho de la fluidez y galanura de estilo que imperan en los discursos feijonianos, lo cual hace que se los lea con fruición, sin cansancio. Esto obedecía a su plan preconcebido de «dejar lijerita la letura y evitar el fastidio a los letores).

Pasa luego a hablar de la cualidad que, en su opinión, debe sobresalir en la poesía: la naturalidad. Concretamente se refiere a Góngora, del cual alaba las obras poéticas de su primera época, las cuales «hechizan por su dulcísima naturalidad; empero las de la segunda época resultan, dice, «insufribles por su afectación vana de cultura». Así pensaba Feijoo de Góngora. Hoy día no comparten su opinión los que, como Dámaso Alonso, han profundizado en la obra poética gongorina ${ }^{26}$.

Concluye la carta con una frase que si por un lado nos hace sonreir por lo que encierra de llana, familiar y espontánea, por otro nos permite entrever las condiciones duras en que tenían que desenvolverse los escritores de antaño, en contraste con el ambiente más confortable de que hoy se disfruta: “Y con esto, escribe, dejo la pluma y me voy a la chiminea».

25 Citada por Marañón, o. c., '270.

26 Cfr. D. Alowso, "Soledades de Góngora, editadas por-. Madrid 1927; In., La lengua poética de Göngora, Madrid 1935; - In,, Góngora y el Polifemo, Madrid 1961, ete. 
11. - Oviedo, 1 de febrero de 1744. Copia. El original, al igual que el de la $2 .^{a}$ y el de la $12 .^{a}$, se quemó en el incendio de 1951. Comienza aludiendo al material bibliográfico sobre los brindis que le había enviado su corresponsal y que Feijoo había de aprovechar en la redacción de la carta XIV del tomo segundo de Cartas Eruditas, aparecido en 1745, sobre el "Origen de la costumbre de brindar». Nos encontramos nuevamente ante una prueba más del papel tan destacado que desempeñó el eruditísimo Sarmiento en la elaboración de las cartas y discursos feijonianos.

En el párrafo siguiente se refiere a un retrato suyo hecho por el pintor ovetense Francisco Bustamante. Reprueba la forma del hábito con que lo representa, la cual se asemeja al hábito capuchino. Alaba la figura del rostro (bien sacado de la lámina»; pero no así la viveza y agrado de los ojos, en lo que fallaba siempre Bustamante, quien «en todas sus copias... deja unos ojos neutros o indiferentes».

De los retratos que se le hicieron en vida son conocidos, a más de éste de Bustamante, los que aparecen en las ediciones del Theatro de 1765 y 1783, grahados respectivamente por J. Ballester y por Palomino; el de Vázquez, grabado por José Maea, el cual puede verse en Marañón, Las ideas..., frente a la p. 288; y el que pintó Granda cuando el P. Maestro contaba 87 años de edad y que reproduce asimismo Marañón en la misma obra a continuación del de Vázquez. También se cita otro pintado por Santiago Lavan el mismo año de la muerte de Feijoo ${ }^{26 \mathrm{~b}}$.

12." - Oviedo, 5 de junio de 1748. Es copia del original que, como el de la $2 .^{a}$ y $11 .^{a}$, estaba expuesto en la llamada celda del P. Feijoo, en donde pereció en el incendio del 24 de septiembre de 1951 con los demás papeles, libros y muebles que en ella se custodiaban.

Es muy corta y de tema estrictamente confidencial e íntimo: sobre ciertos asuntos particulares concernientes a algunos de sus hermanos de hábito.

Reviste singular interés para el monasterio de Samos por la referencia que hace del general de la congregación de San Benito de Valladolid, P. Plácido Cortada (1745-49), ra quien la Casa de Samos debe levantar

26. b El primus retrato de Feijoo, al que alude cun la frose "bien sucado de la láminam, es ell grabado de Moreno Tejadas que figura al fronto del primer tomo del Teatro, od. de 1733, reproducido en la ed. de 1781, y det eque procedea los de Ballester y Palomino (Nota de J. M. C. G.). 
estatua», por cuanto (cen el espacio de dos años le dio dos plazas escolásticas y tres oratorias». Bien nos gustaría saber concretamente los nombres de estos cinco monjes samonenses agraciados por el general. Atendiendo a la fecha, año 1748, creemos que entre ellos muy bien pudo haberse contado el P. Eladio de Nóboa, de quien sabemos que «por orden del general se dirigió a Salamanca... para enseñar teología en aquella famosa universidad" ${ }^{27}$. Rigió los destinos de la abadía en dos cuatrienios (1749-53 y 1769-73). El fue quien predicó la oración fúnebre en las exequias que se celebraron en Samos el 22 de enero de 1765 en sufragio del alma del P. Feijoo.

Otros de los agraciados pudieron haher sido también el P. Antonio de Puga, que era, al parecer, pariente del propio Feijoo ${ }^{28}$, y el P. Agustín Lasanta, los cuales, años más tarde de la fecha referida, brillaban como catedráticos en la universidad salmantina.

La frase efusiva del insigne hijo de Samos que estamos comentando parécenos interpretarla, además de lo que en la carta se apunta, por el hecho de que la abadía se hallaba por aquellas fechas en un trance feliz de su historia. Se habían construido ya tres lienzos del olaustro grande y reconstruido los dos pisos del pequeño o gótico; $y$, sobre todo, estaba a punto de ser inaugurada la actual iglesia, en cuya realización tanto había influido el P. Feijoo: él había exhortado y animado a los abades de Samos "a esta obra, que excedía las fuerzas de el monasterio», en frase de su panegirista el P. Nóboa ${ }^{29}$; así como también había colaborado, más que nadie, en su construcción aportando buena parte del dinero obtenido con la venta e impresión de sus obras ${ }^{30}$. Lo cual no quiere decir, sin embargo, que fue construida exclusivamente con sus importantes aportaciones ${ }^{31}$.

Y aun hay más. En la fecha en que escribía esta carta tendría ya pre-

27 P. Arias, Historia del real monasterio de Samos, Santiago de Compostela 1950, 313.

28 In., ibid., 322.

29 Е. Nóвоа, Oración fúnebre..., 24.

30 «Por ser el P. Maestro Feijoo hijo profeso de la casa de Samos, cedióle en vida, para quo ella pudieso groseguin la fábrioa de su nueva '́glosia, el uso de todo al útil que podrán producir lodns las reimpreaiones de sus escritos (M. Sarmiento, Manifiesto del recibo de rentus de los monasterios de lo religión de san Banito y en qué se emplean, Santiago 1879, 117). Véase también E. de Nóboa, Oración frínebre..., 46.47.

31 P. Arias, El P. Feijoo y la iglesia de Samos: Boletín de la comisión provincial de monumentos históricos y artísticos de la provincia de Lugo 2 (1945-47) 51-53. 
parado, o lo estaría preparando, el sermón para la inauguración de nuestro templo samonense el 11 de julio de 1748 , si hemos de creer en una tradición recogida por Murguía, según la cual fue el P. Feijoo quien lo predicó: «a quien sin duda alguna consideraban acreedor a esta insigne muestra de aprecion" ${ }^{32}$.

13. ${ }^{\circ}$ - Oviedo, 24 de julio de 1748. Manifiesta su dolor por la muerte del P. Vallejo, a quien van dirigidas las dos cartas de Feijoo que ponemos en apéndice. Era dicho padre conventual de San Martín de Madrid, en donde ejercía el cargo de predicador. El mismo que desde 1734 le llevaba el asunto administrativo de sus publicaciones.

Habla a continuación de una epidemia de viruelas que estaba diezmando a los niños de Asturias, las cuales eran (más infanticidas que Herodes»; y de otra de (tabardillos» o tifus que, entre otros, se llevó a un usurero, quien, para colmo, dejó escrito en su testamento «que no debía nada a nadie». "Dios nos libre, concluye Feijoo, del detestable viçio de la avariçia».

14. ${ }^{\mathrm{a}}$ - Oviedo, 17 de abril de 1749. Nos es del todo desconocida Ia personalidad del P. Carasa, de quien se ocupa la presente carta. Por cierto que el mencionado sujeto no queda muy bien parado, en cuanto a su capacidad intelectual, en las frases que aquí se le dedican.

Marañón deduce de esta carta «el rigor crítico con que Feijoo procuraba la buena enseñanza, no sólo en las universidades, sino en su colegio mayor de Oviedon ${ }^{33}$.

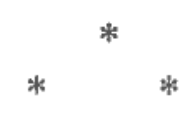

Después del somero comentario que acabamos de hacer a cada una de las catorce cartas feijonianas, pasamos a transcribirlas, no sin antes advertir que en su transcripción hemos respetado su peculiar ortografía, limitándonos a regularizar las letras mayúsculas y minúsculas, a completar las abreviaturas y a amoldar los signos ortográficos a las normas actualmente en uso.

Maximino Arias

Monje de Samos

32 M. Murguía, Diccionario de escritores gallegos, art. Feijoo, Vigo 1862, 201

33 G. Marafión, o. c., 37, nota 2. 


\section{T E X T O D E LA S C A R T A S}

1729, abril, 30. Oviedo

Dificultades para la aprobación del tomo ili del teatro.

Archivo del monasterio de Samos (=AMS), carp. C 1, núm. 1. Original autógrafa.

Pub.: G. Marañón, Las ideas biológicas del P. Feijoo, Madrid 1934, 141, nota 1.

Amigo i señor: Este correo rezibo carta de el illustríssimo en que me dize no sé qué de embrollos de el padre Ania sobre aprobaçión i alboroto de los capuchinos sobre la espeçie que toco do el padre Carabantes, añadiendo que supone que vuestra merced me avrá escrito una i otra espeçie; y como no he tenido otra que ésta confusa i vaga que me da su illustríssima, lo que discurro es que los capuchinos, sabidores de lo que escribo de su missionero Carabantes, hizieron con Ania que negasse o suspendiesse la aprobaçión. Sea esto o sea otra cosa, es menester discurrir allá i tomar el expediente que ocurriere más oportuno para salir de este pantano, o reimprimiendo con emienda el medio pliego donde está el escándalo o más si fuere menester, o añadiendo al principio o fin alguna nota, etc. En fin, yo doi mi poder cumplido para borrar, mudar o añadir todo lo que parezca conveniente; $\mathrm{i}$ espero en Valladolid ${ }^{34}$ aviso con toda expressión de lo que ai en la materia.

34 En el monasterio de San Benito de Valladolid, adonde habia de acudir el P. Feijoo al mes siguiente para tomar parte en el capitulo general. 
Nuestro Señor guarde a vuestra merced muchos años.

De ésta ${ }^{35}$ de vuestra merced. Oviedo i abril 30 de 1729.

Besa la mano de vuestra merced su más seguro servidor i amigo,

Fr. Benito Feijoo [rubricado]

Mi padre maestro Sarmiento, mi amigo i señor.

1732, mayo, 22. Oviedo

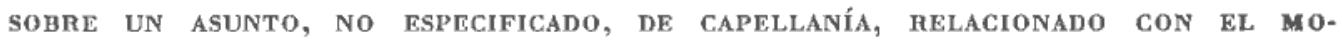
NASTERIO DE MONTSERIRAT, DE MADRID.

AMS, carp. C 1, núm. 2, Copia.

Padre nuestro, amigo y señor: Conociendo que no tenía inconveniente leer al reverendísimo la carta en que vuestra paternidad me expone todo lo que hay en asunto de la capellanía, lo hice así. Su reverendísima estaba muy bien enterado del hecho y de los motivos, pero dice que él no tiene autoridad para obligar a la casa de Monserrate, que ése es negocio de la congregación; y me parece descubrí en su reverendísima el deseo de proponerlo cuando llegue el caso, de modo que la voluntad del difunto se cumpla enteramente. Su reverendísima parece estaba persuadido que se habían convenido las dos partes con el coste de ceder de los 200 ducados los 50 a la casa de Monserrate; y yo téngolo esto por muy de hacer y de equidad, aunque no de rigurosa justicia. Representéle cuanto alcancé en el asunto. No sé si servirá. Ya escribo a nuestro padre visitador que reimprima la Apología. Remito ese discurso. No sé si podré remitir algo más. El correo que viene lo tendré averiguado.

Nuestro Señor guarde a vuestra paternidad muchos años. Oviedo y mayo 22 de 1732 .

Padre nuestro, su amigo y servidor de corazón,

\section{Fr. Benito Feijoo}

Nuestro padre Sarmiento, mi amigo y señor.

35 Se sobrentiendo casa o celda. 


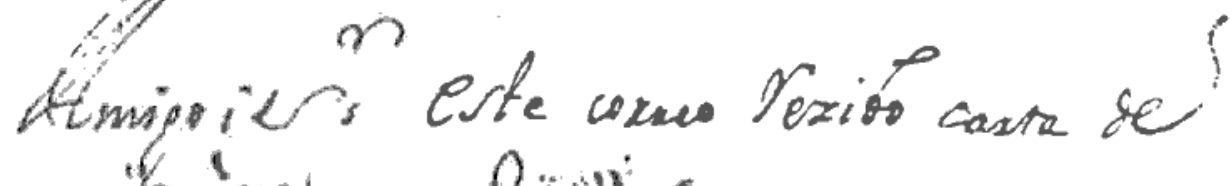

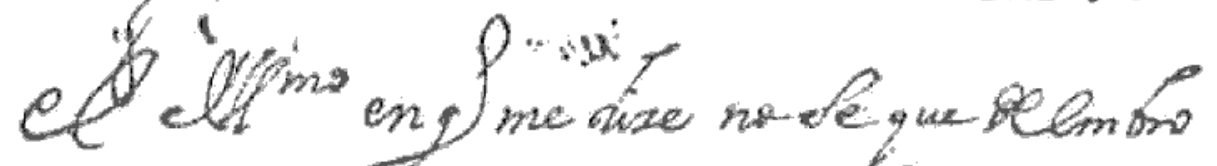

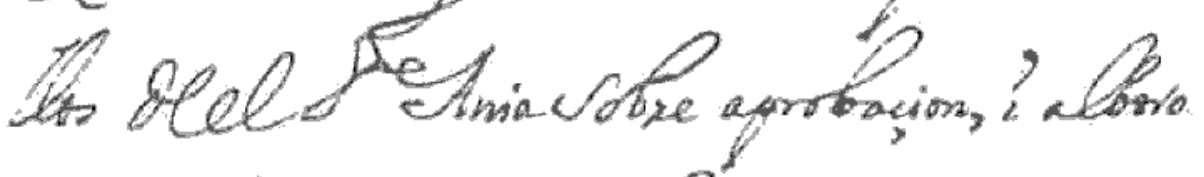

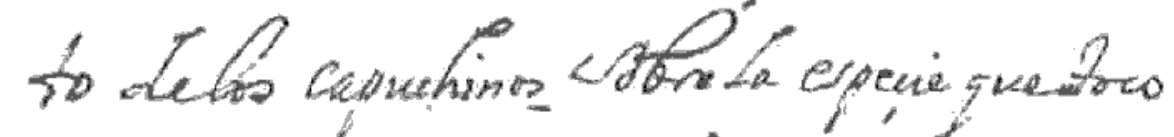

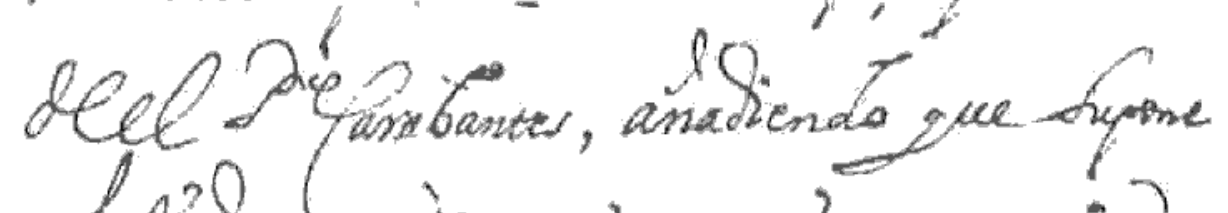

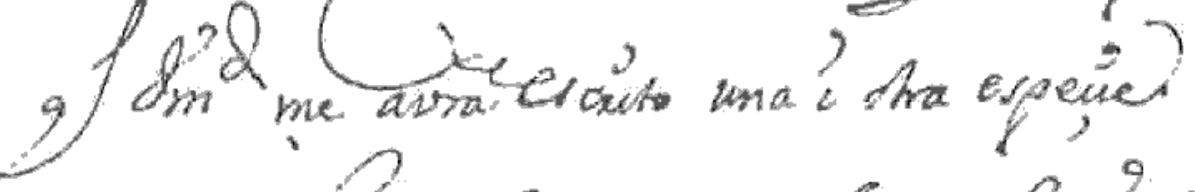

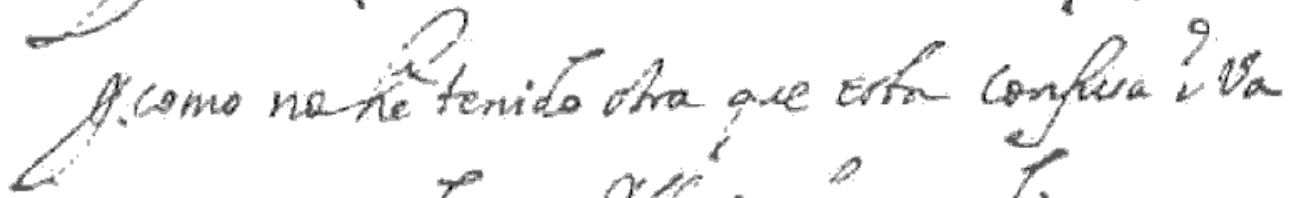

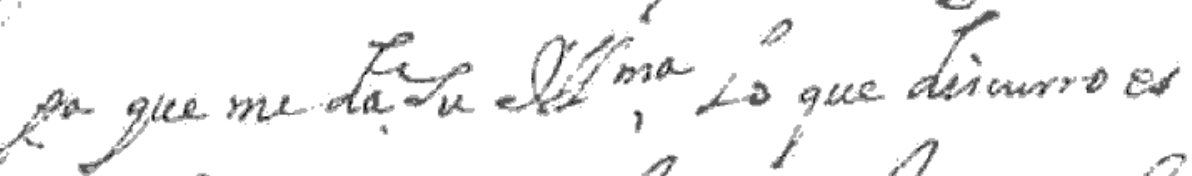

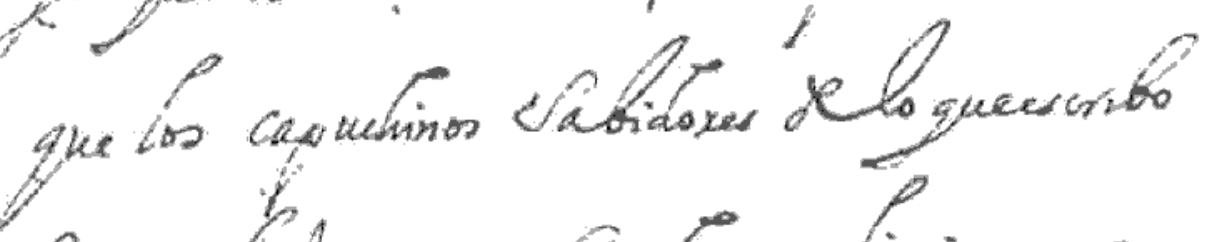
Le suthisionerof arebenter hizierm ton Hnia que nepase oxtupendiesse ha aprobiun Cea elfo, odea diracosa, es menater onswior ata, i ctomar elesorediente que oumine

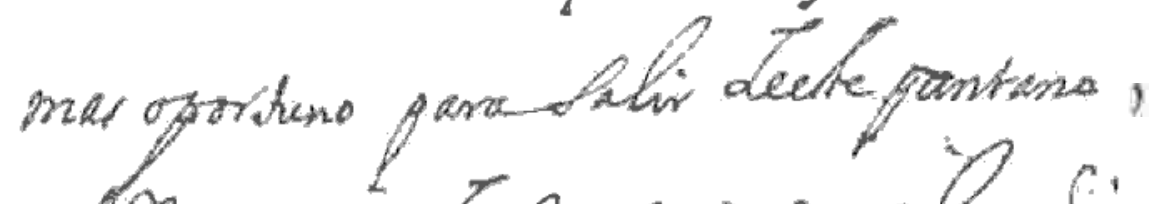

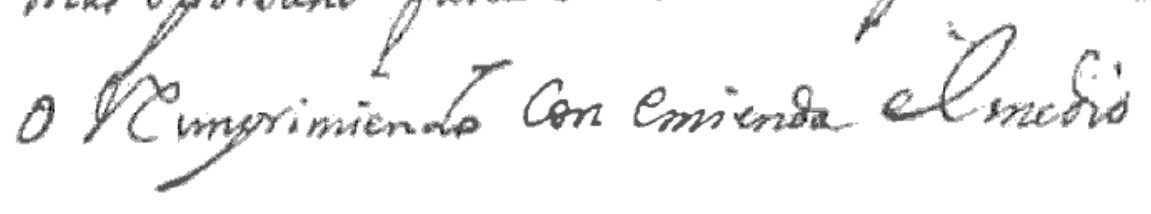




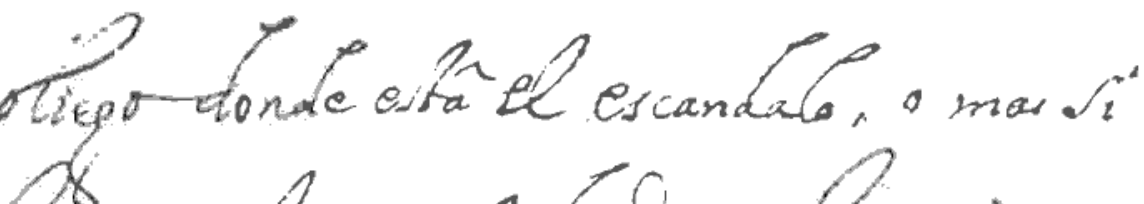
pure meneifer, a añadiendo a formato

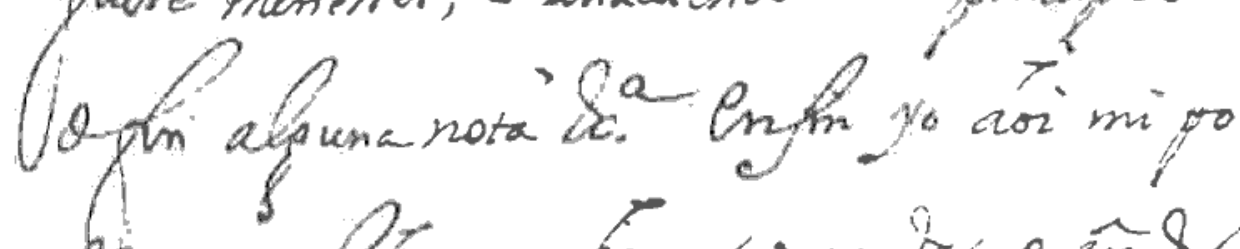

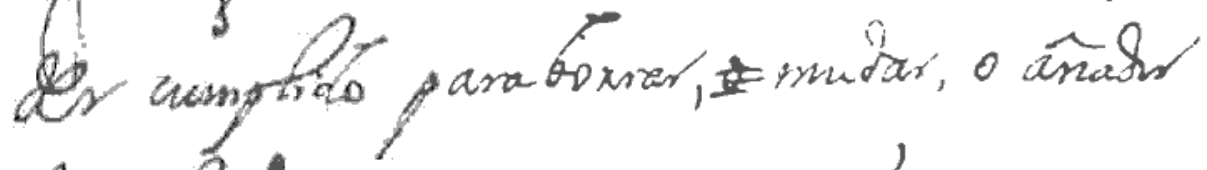

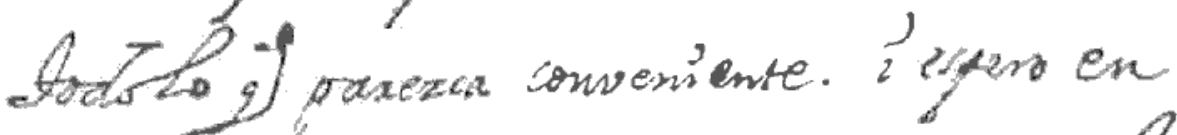

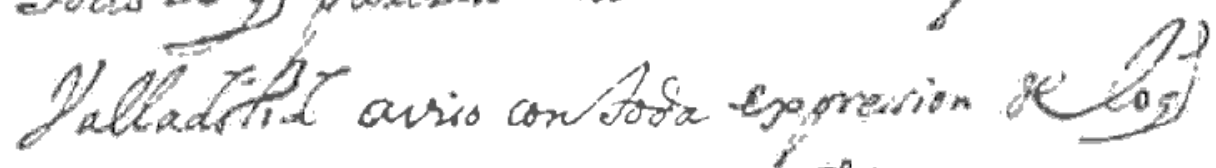

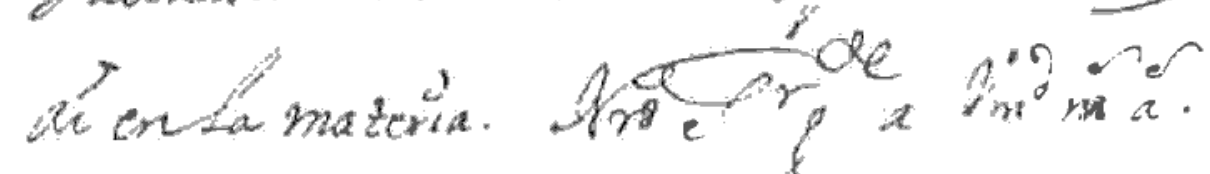

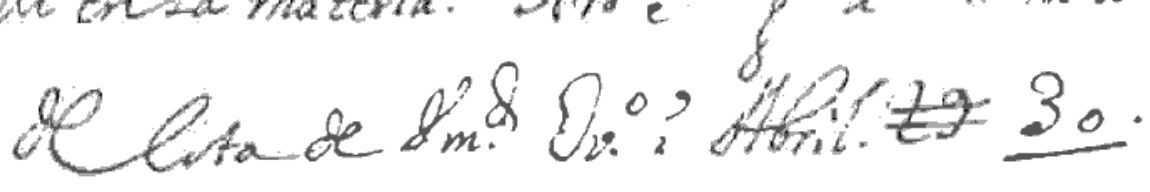
seto2s.

0. C. Sh. de $8 \mathrm{~m}^{2}$

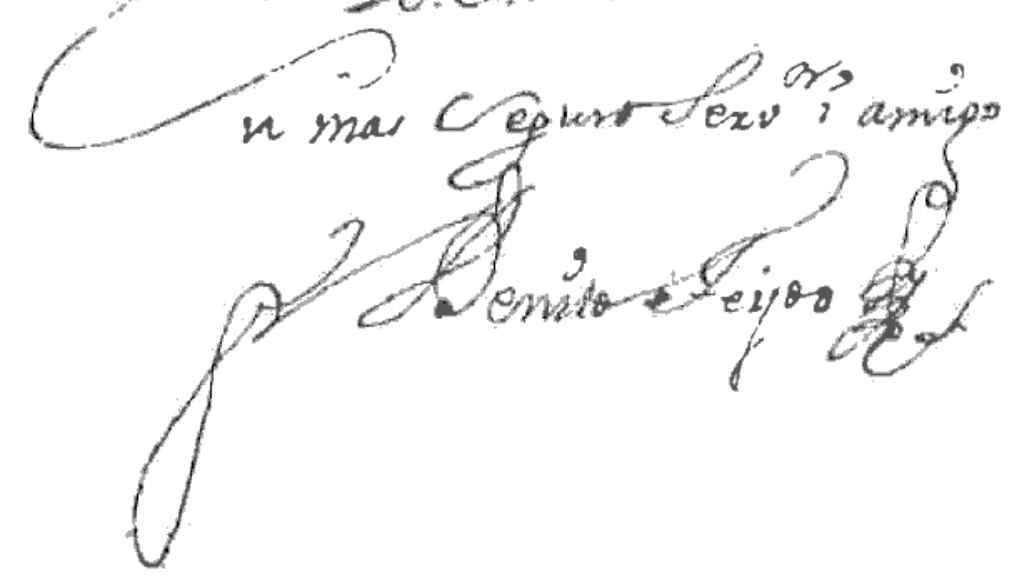

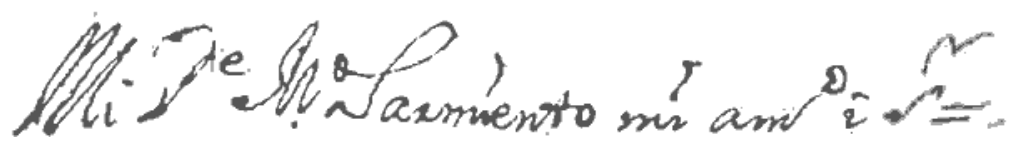


1732, junio, 14. Oviedo.

pide a sarmiento le envíe una lupa, dos resmas de papel $Y$ un poco de taBACO.

AMS, carp. C 1, núm. 3. Original autógrafa.

Pub., en parte: G. Marañón, o. c., 299.

Amigo i señor: Según lo que me escribe don Joseph Pardo ${ }^{36}$, ya vuestra merced salió de la prensa porque su escrito entró en ella, conque para el correo que viene espero veer los primeros pliegos.

Aquel vidro [sic] grande que hemos comprado i costó 240 reales, salió cassi totalmente inútil; lo uno porque representa la letra con alguna confusión, lo que fatiga la vista, lo otro porque la aumenta poco si no se pone a mucha distançia de el libro; de modo que la magnitud de este género de vidros aumenta el preçio i disminuye la utilidad. Yo esperaba, en quanto a la segunda parte, lo contrario; pero la experiencia me ha mostrado que para su cómmodo usso ni deben pasar de çinco dedos de diámetro, ni bajar de tres i medio. Fuera de esto deben probarse para veer si representan la letra con claridad, porque ay en esto summa diferençia de unos a otros. Yo compré aí a un francés que los vendía uno bellíssimo de quatro dedoo de diámetro por dos reales de a ocho, i el mismo pedía ocho pesos por otro que tendría hasta siete dedos de diámetro, siendo assí que éste no aumentaba la letra más que el otro, ni la representaba con tanta claridad.

Hago memoria de todo esto porque neçessito indispensablemente uno de estos vidros para leer de noche los libros de letra menuda, que sin este subsidio apenas puedo o lo hago con mucha fatiga. Assí es menester que vuestra merced me lo busque i pruebe por sí mismo, i hallándole bueno, no reparar en el preçio. Sea luego, porque Argüelles ${ }^{37}$ está de marcha para allá.

36 Creemos sea el mismo don José Pardo de Figueroa, de quien habla en el discurso IV, n. 6, del tomo VI del Theatro Crítico al describir el pez del que se extraía la púrpura; le llama “curiosissimo y eruditíssimo caballero». Era miembro de la Real Academia.

37 Repetidas veces lo menciona. Era, sin duda, un arriero ovetense que, como tantos otros, recorria por aquel entonces los caminos de España transportando sus mercancías. En la carta 4 se menciona a Argüelles el viejo. 
De Pontevedra me escrivieron que un sobrino de vuestra merced deseaba tomar el santo hábito, conque la palabra que el abad de Samos me tenía dada para un muchacho de aquí (pariente mío por los Pumarinos) lo conmuté a favor de esotro, i discurro no tarde mucho en ser noviçio.

Quedo a la obediençia de vuestra merced, cuya vida guarde Nuestro Señor muchos años.

Oviedo i junio 14 de 1732.

Besa la mano de vuestra merced su servidor i amigo de corazón,

$$
\text { Fr. Benito Feijoo [rubricado] }
$$

Mi padre nuestro Sarmiento, mi amigo i señor.

[Nota marginal:] En mano de vuestra merced pondrá su paternidad Rodríguez ${ }^{38}$ un poco de tabaco para el regente de este colegio, i Figueroa ${ }^{39}$ dos resmas de papel para mí; que todo, juntamente con el vidro que pido, se entregará a Argüelles.

1733, enero, 9. Oviedo

PIDE AL P. SARMIENTO LE COMPRE CIERTOS LIBROS QUE NECESITA, AL TIEMPO QUE le anUNCia el envío de una cantidad de lienzo asturiano.

AMS, carp. C 1, núm. 4. Original autógrafa.

Pub.: G. Marañón, o. c., parte en p. 141, nota 2 y parte en p. 142, nota 3.

Cita: G. Delpy, L'Espagne et l'esprit européen. L'oeuvre de Feijoo (1725-1760). Libr. Hachette 1936, 281 y $385,2 .^{\text {a }}$ col.

Padre nuestro y señor mío: Házeme fuerza lo que vuestra paternidad me dize de la disonançia que hará el corto número de discursos, i assí resuelvo, dejando por aora el de la poesía, dedicarme a dos o tres corticos, porque el de la poesía ha de salir larguíssimo. Digo que vuestra paternidad

38 Se trata del P. Alonso Rodriguez, profeso de Carrión. Fue maestro general de la congregación, teólogo de la junta de la Inmaculada, y abad de San Martín de Madrid (1725-29).

39 Véase la nota 36. 
420

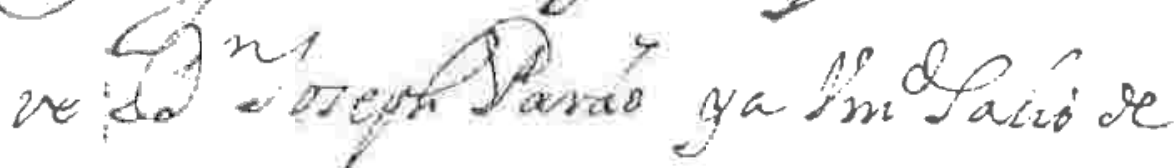

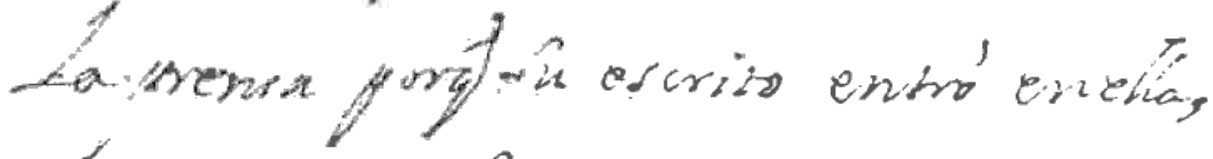

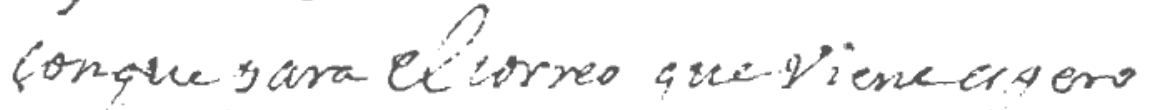

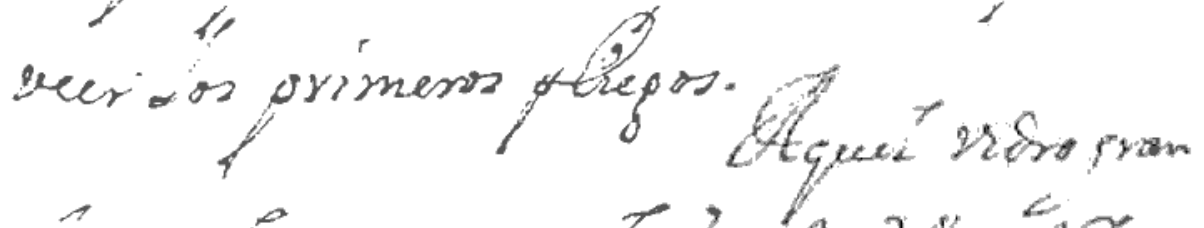

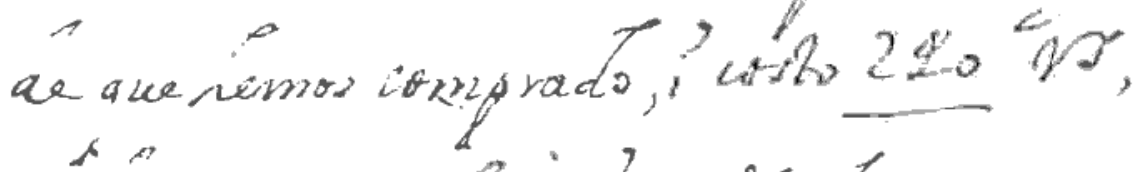

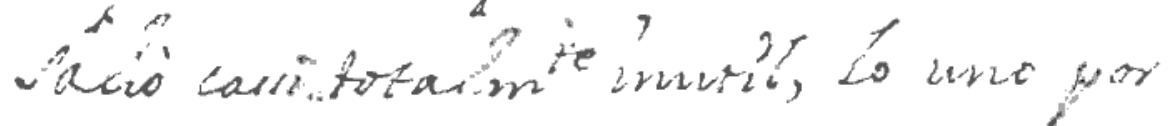

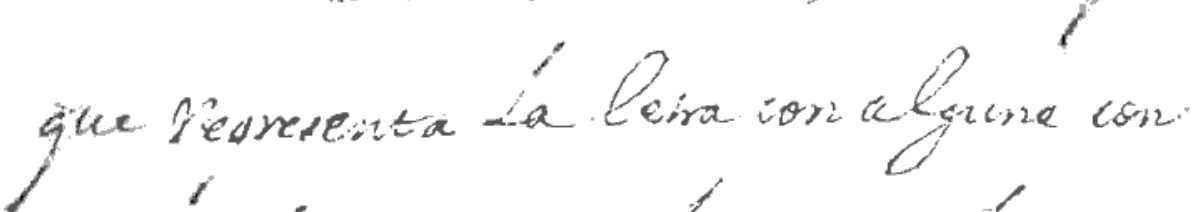

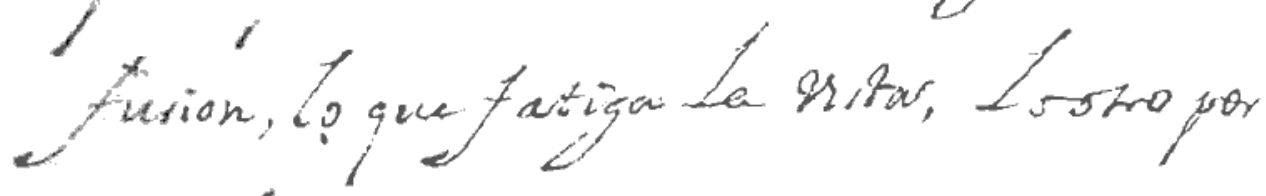
que La aumentar poro ons ve fone amu.

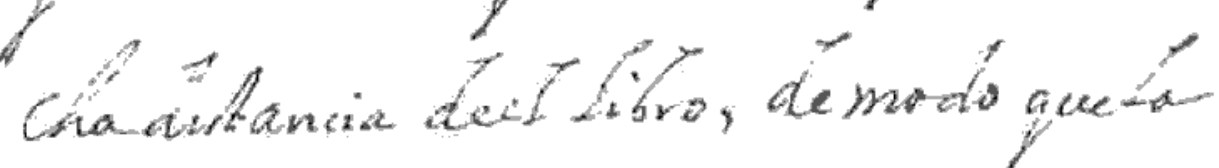

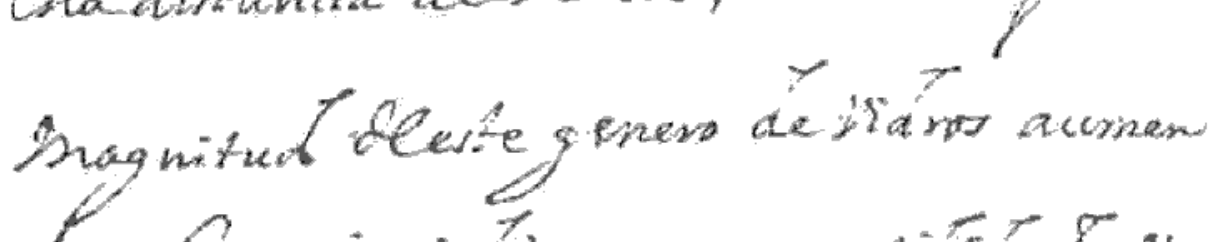

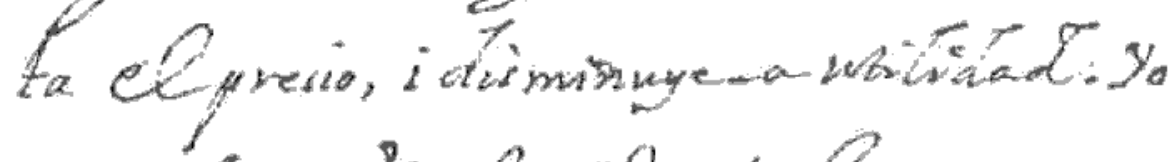

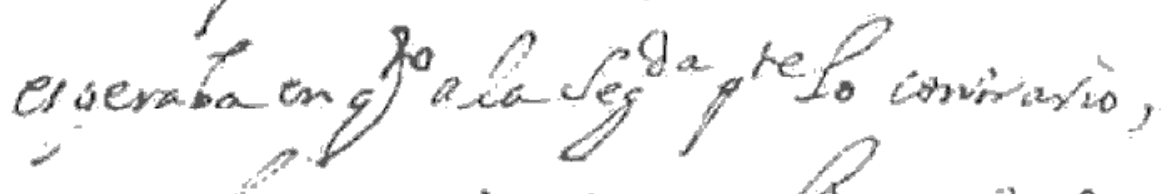
pero ta experientia me ha morimado, 
guegara ha conmodo uso mi deben pa Can de uno dedos dediamero, nibayar.

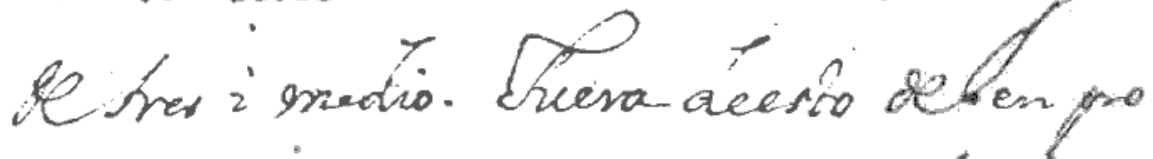

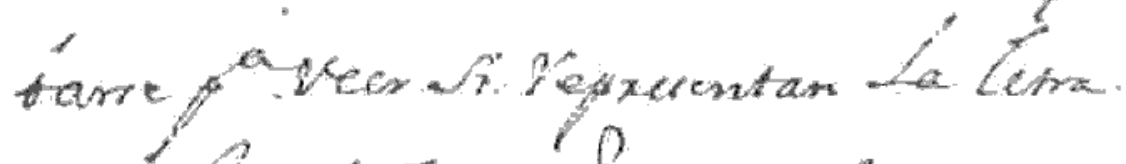
ion ckaridat fory ay en elo smma.

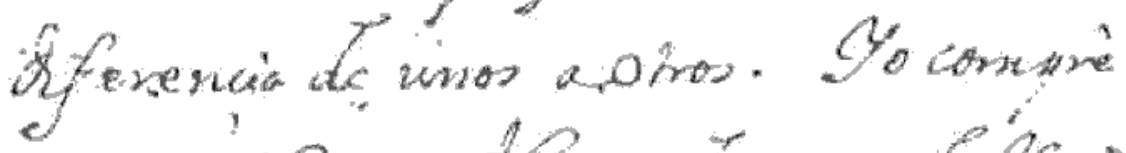

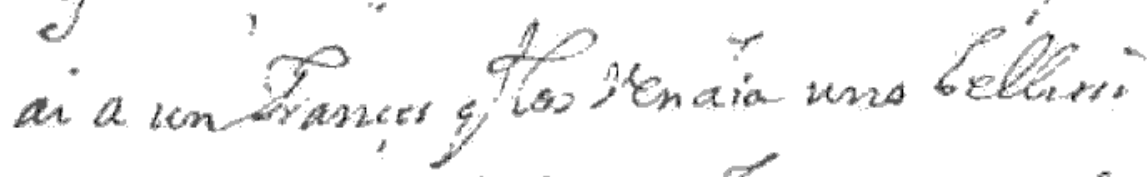
mo de quario dedor be diametro goo deo

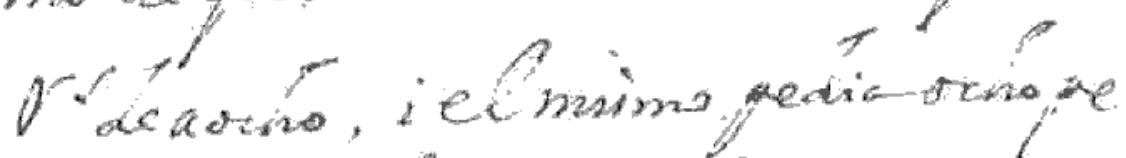

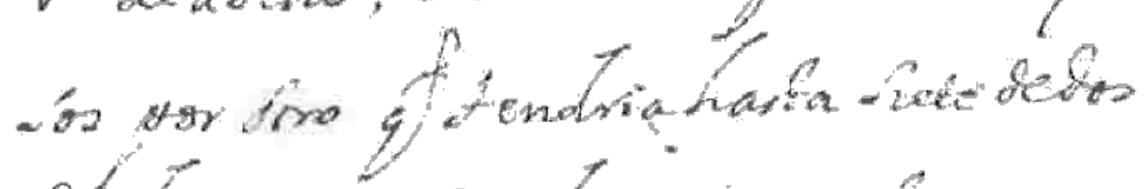

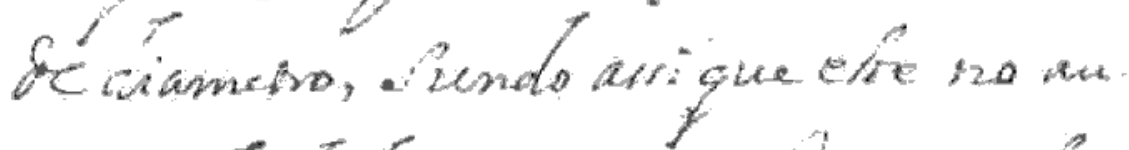

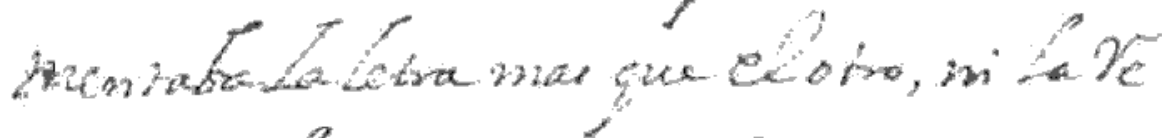
therentabe con fanta Clavidar. thago

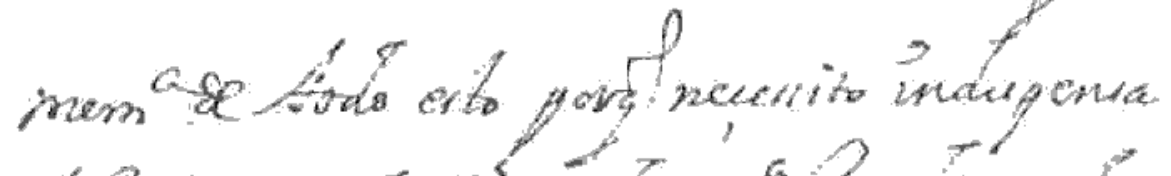

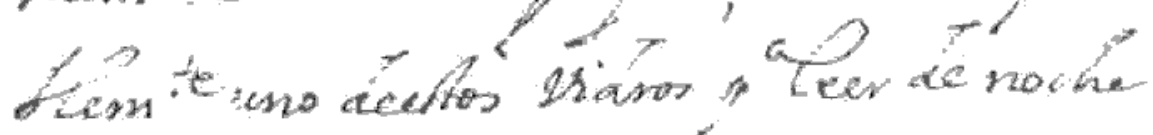

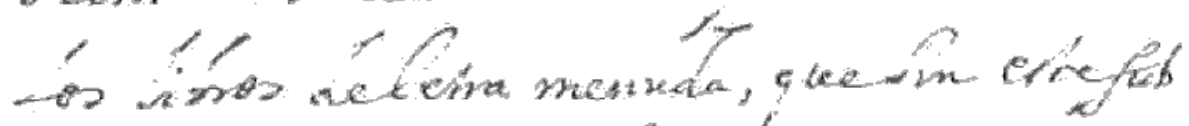

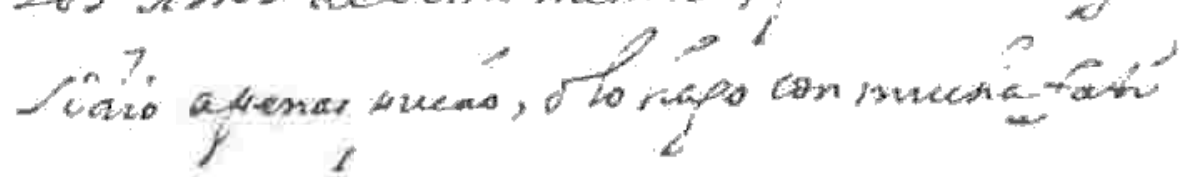




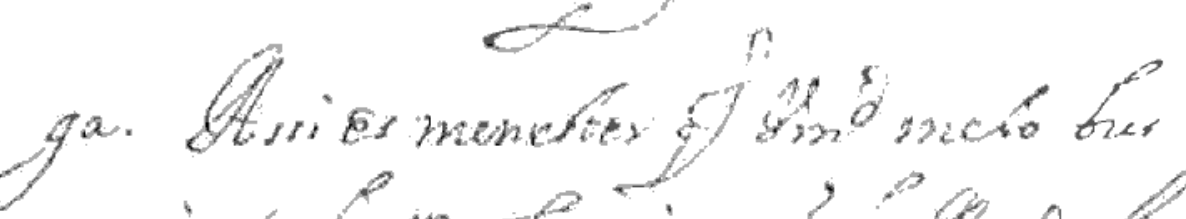

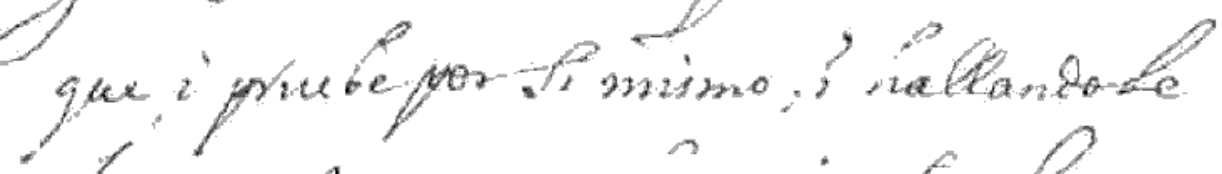

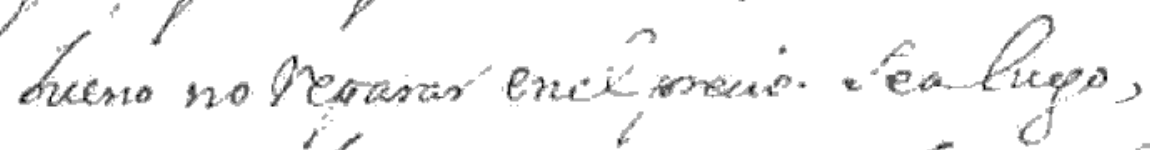

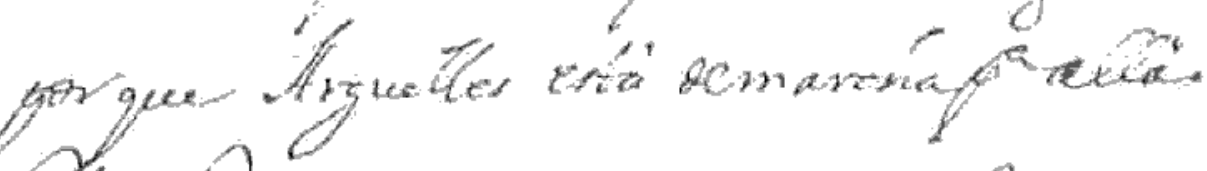

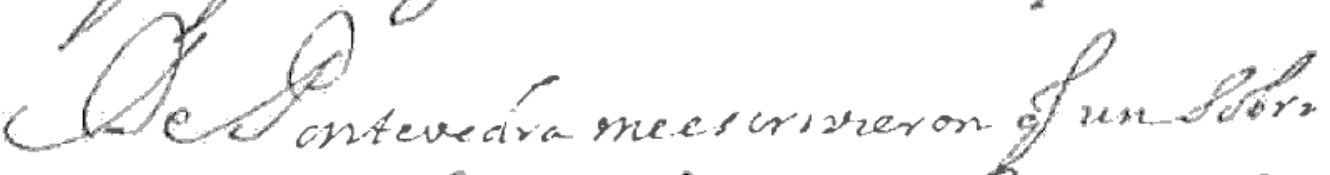

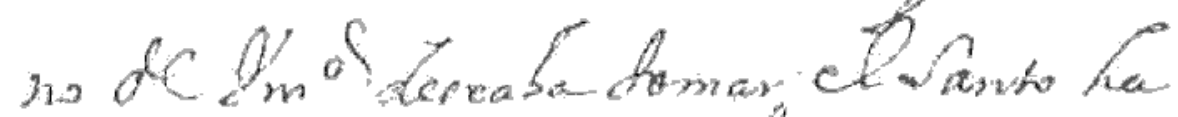

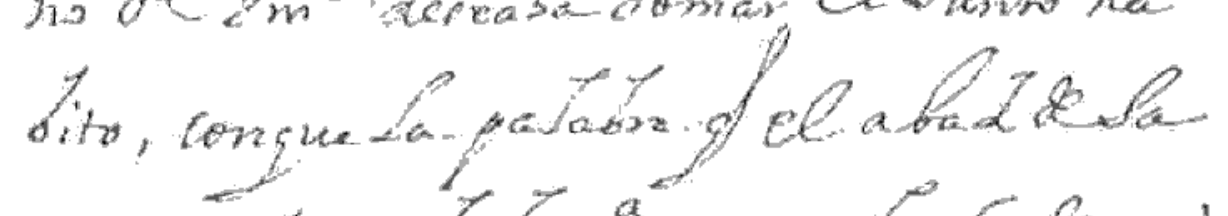

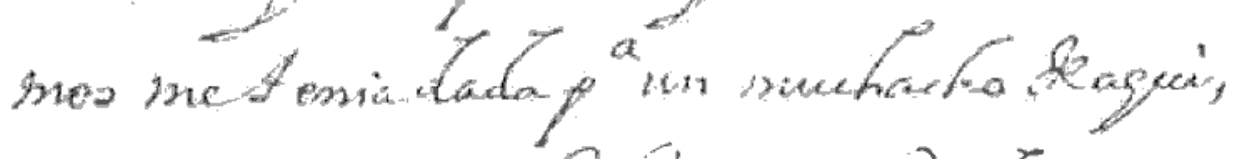

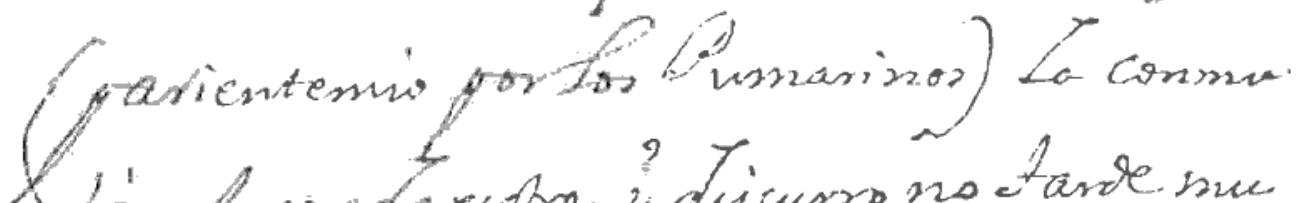

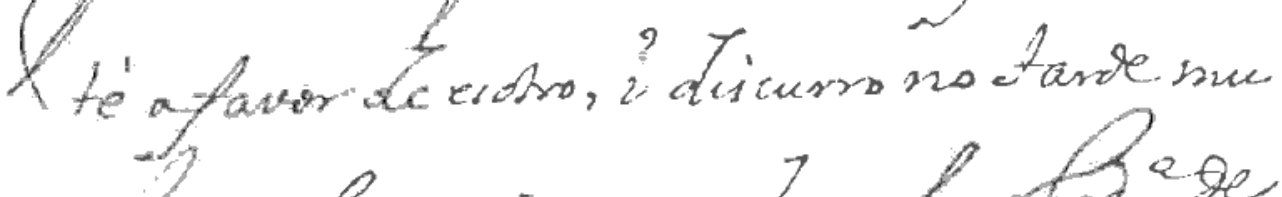
tho enter novicro. quedo a Latobate

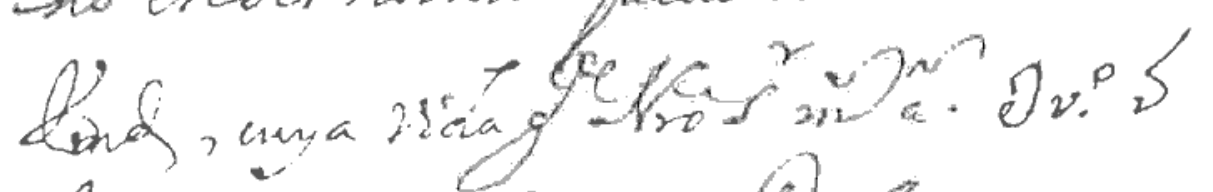

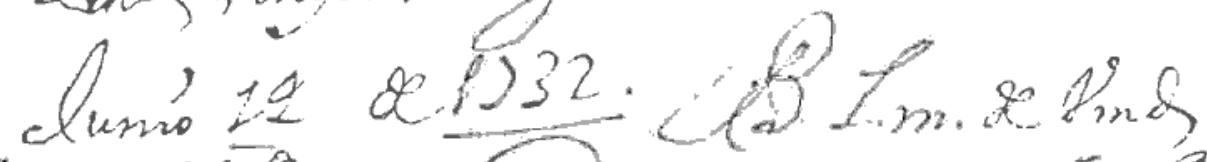

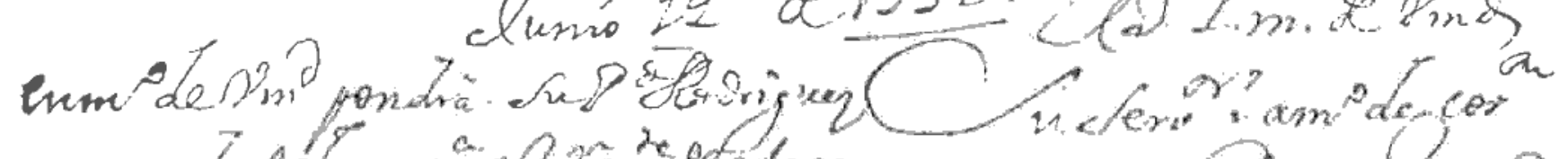

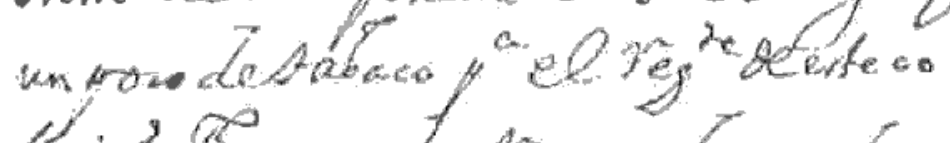

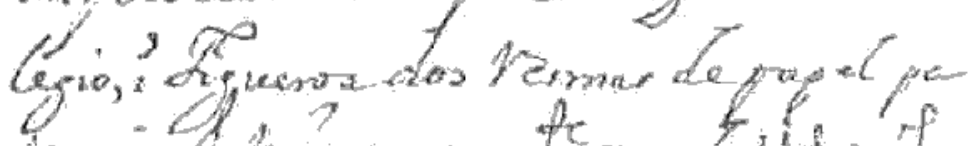

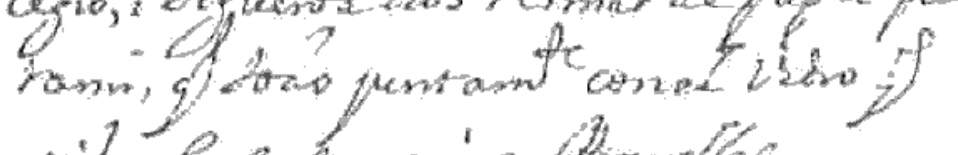

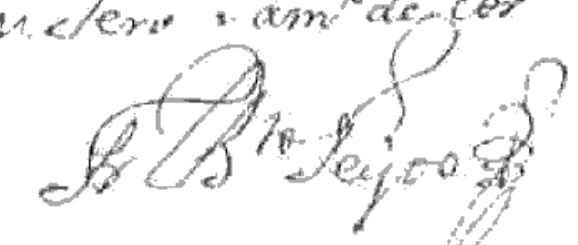

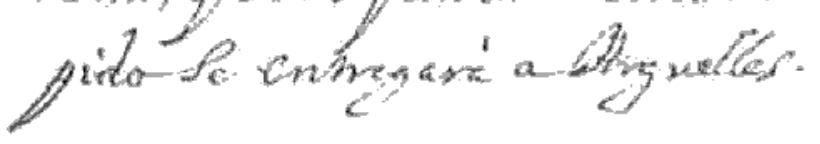

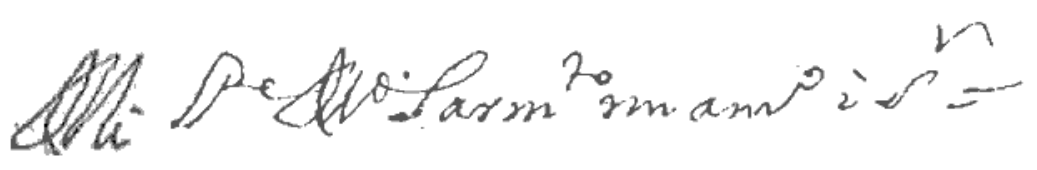




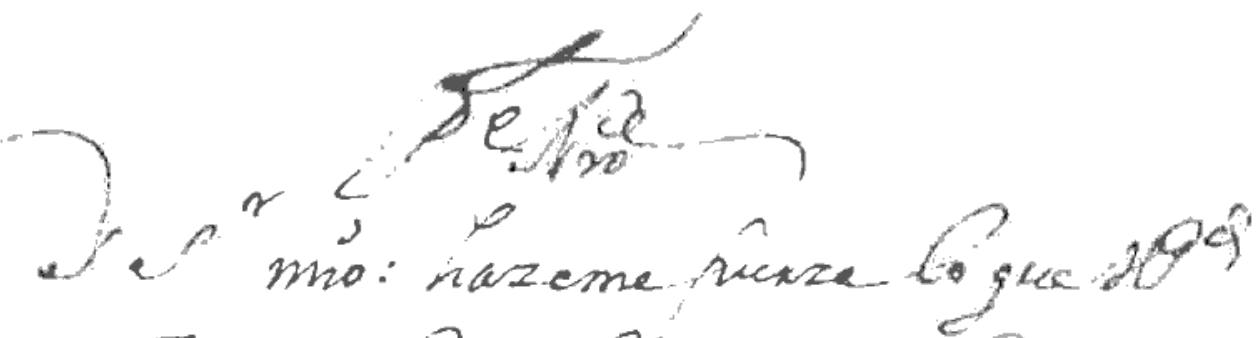

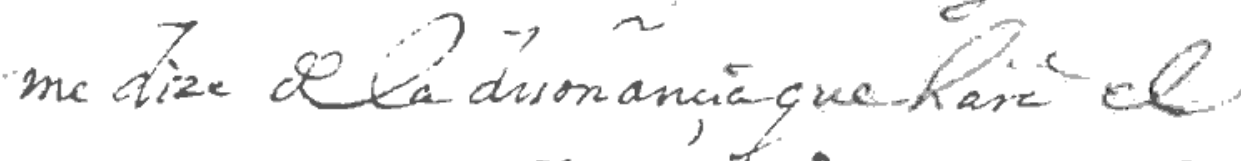

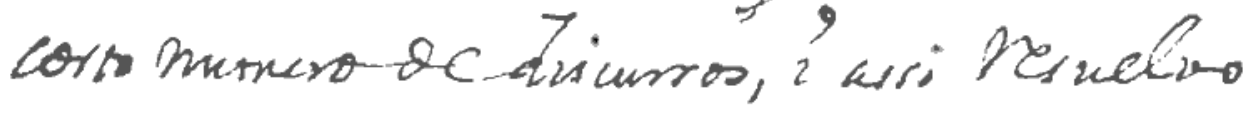

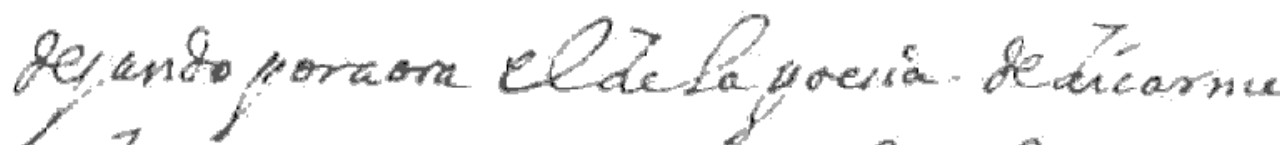

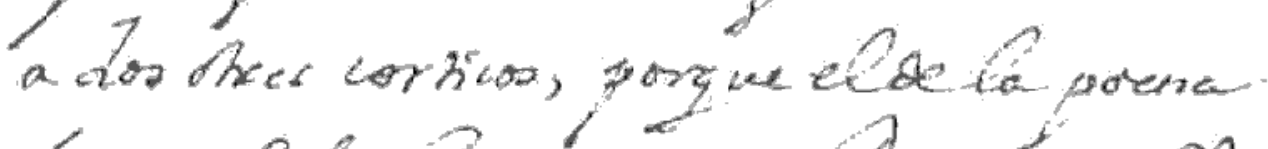

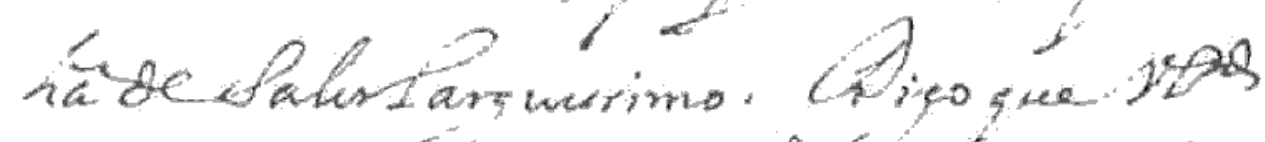

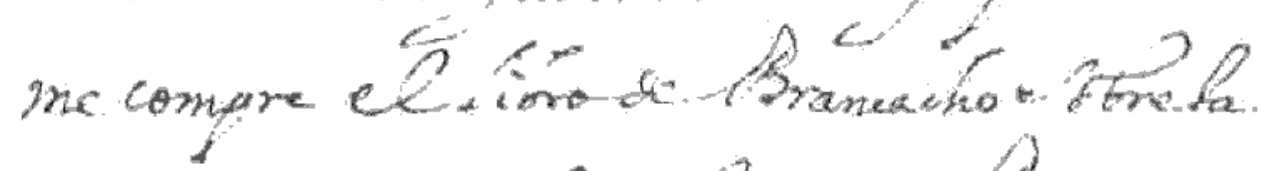

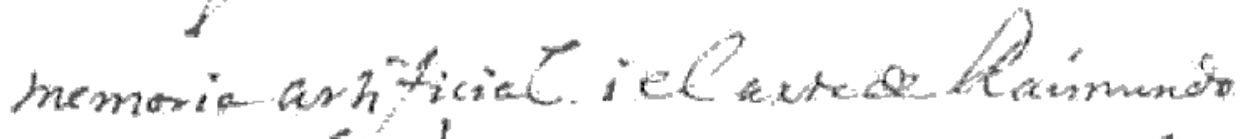

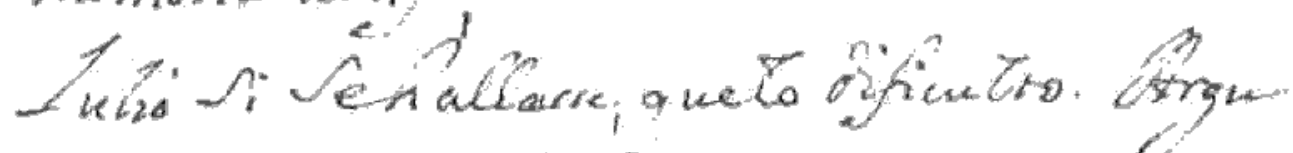

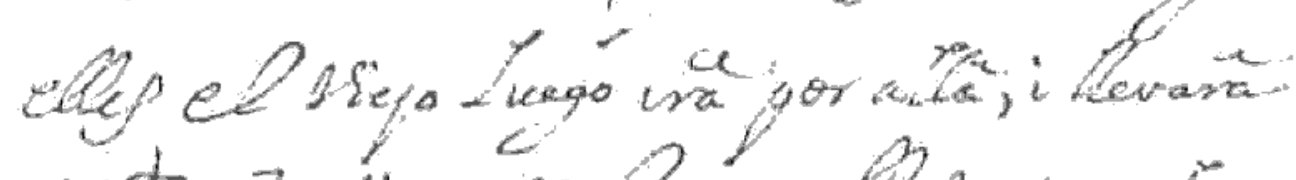

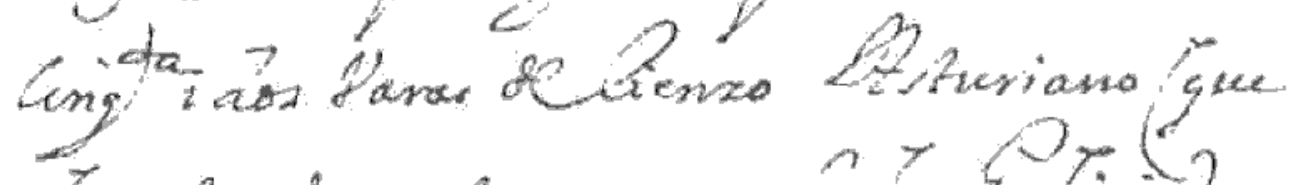

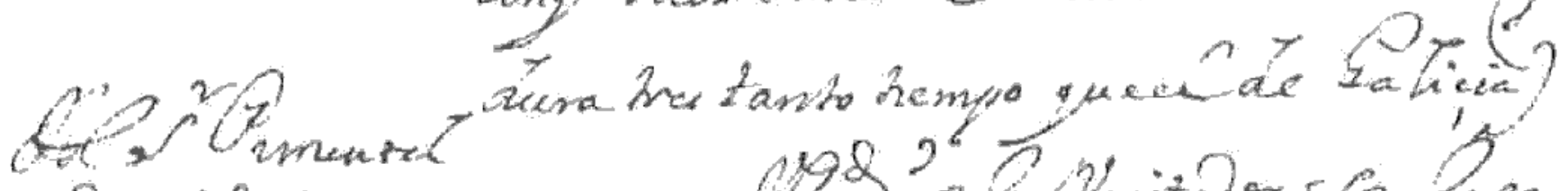

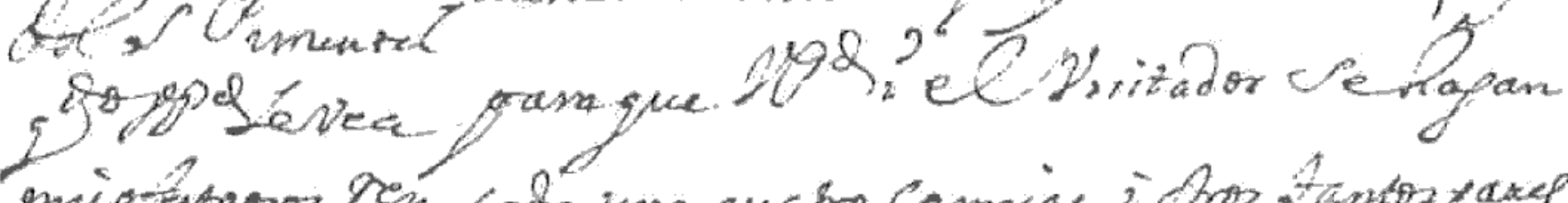

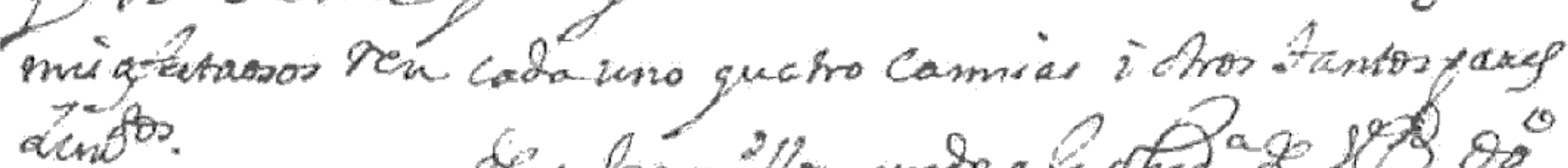
cualionzitlo quedo a ieng. det 133 .

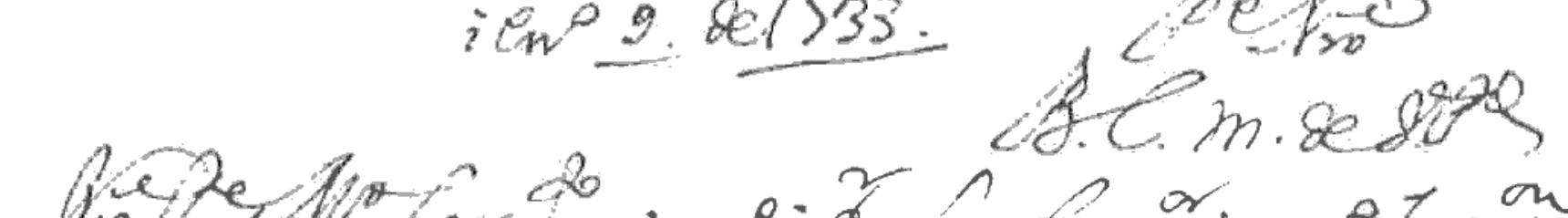

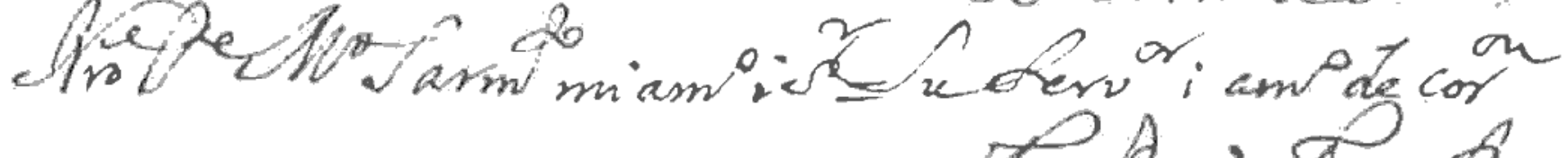

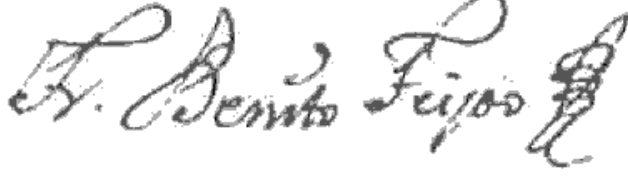


me compre el libro de Brancacho sobre la memoria artifiçial i el Arte de Raimundo Lulio si se hallasse, que lo dificulto. Argüelles el viejo luego irá por allá i llevará çinquenta i dos varas de lienzo asturiano (que dura tres tanto tiempo que el de Galiçia) para que vuestra paternidad i el visitador ${ }^{40}$ se hagan cada uno quatro camisas $\mathrm{i}$ otros tantos pares de calzonzillos.

Quedo a la obediençia de vuestra paternidad.

Oviedo i enero 9 de 1733.

Padre nuestro, besa la mano de vuestra paternidad su servidor $\mathrm{i}$ amigo de corazón,

\section{Fr. Benito Feijoo [rubricado]}

Nuestro padre maestro Sarmiento, mi amigo i señor.

[Nota marginal:] Al señor Pimentel, quando vuestra paternidad le vea, mis afectuosos rendimientos.

1738, mayo, 31. Oviedo

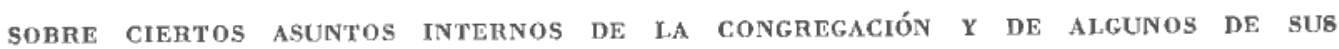
INDIVIDUOS. TEMPERAMENTO LIMOSNERO DE FEIJOO. SOBRE REMESAS DE TABACO.

AMS, carp. C 1, núm. 5. Original autógrafa.

Puls.n en parte: G. Marañón, o. c., 142, nota 1 y 307 , nota 3.

Cita: G. Delpy, o. c., 281 y $385,1 .^{2}$ col.

Padre nuestro y mi dueño: Pedi a nuestro amo ${ }^{41}$ las dos cosas. En orden a la primera dijo que daría gusto al maestro Mariño ${ }^{42}$; ésta fue su

40 Se refiere al P. Sebastián de Vergara, profeso de Silos y abad del mismo (1721.25). Ejerció el cargo de visitador con estancia en San Martín de Madrid en el cuatrienio 1733-37. Debo esta identificación, al igual que la de otros monjes vallisoletanos citados en estas cartas, al P. Ernesto Zaragoza Pascual, de Silos, a quien me complazco mn expresar aquí mi gratitud.

41 El padre general Miguel de Herce (1737-41), monje profeso de San Pedro de Arlanza, el mismo a quien va dedicado el "Suplemento (o tomo IX) del Teatro Crítico», año 1740 .

42 Es el padre Anselmo Marin̄o, hijo y abad de Sahagún (1725-29) y general de la congregación (1741-45). 
expressión. En la segunda dijo haver escrito que se supiesse allá si havia costumbre de proponer para ese efecto a los generales passados. Repliquéle que, aunque huviesse tal costumbre, no debía entenderse con generales passados que ni son ni fueron theólogos; que el exemplar de el reverendíssimo Berganza ${ }^{43}$ fue un absurdo absurdíssimo. Prosiguió diziendo que havía pensado en vuestra paternidad. Respondile que vuestra paternidad quería ese honor para el maestro Vitoria ${ }^{44}$. Conque concluyó en que allá se compusiessen entre los dos, en virtud de lo qual lo doi por compuesto.

Vuestra paternidad no crea a quien le diga que yo estoi escrupuloso. Si hablássemos los dos un brebíssimo rato, vería que el reparo que he hecho en la única materia sobre que puede caer esa nota, nada tiene de nimio. Uno verbo: he sido inmoderado en assumpto de limosnas, i el genio (no la virtud) me arrastra azia eso. ¿No será bueno asegurarme?

Nuestro Señor guarde a vuestra paternidad muchos años.

Oviedo i mayo 31 de 1738.

Besa la mano de vuestra paternidad su servidor i amigo de corazón,

\section{Fr. Benito Feijoo [rubricado]}

Tube carta de don Francisco Xavier Blanco ${ }^{45}$, hijo de don Matheo, con la notiçia de la muerte de éste, que he sentido mucho. Ofréceme continuar las remesas de tabaco, como su padre hazía, i embiar luego seis libras de tabaco que yo le havía encargado. Conque es menester pagarle las seis que quedé debiendo a su padre y las que ofreze, quando vengan. El último tabaco de la Havana que embió Vorges, es bajíssima cosa.

Es menester que vuestra paternidad me compre los 3 tomos de moral de el padre Gobat i pida de Françia la explicaçión literal de los ritos de la Iglesia de nuestro monge don Claudio Vert.

43 P. Francisco de Berganza, general de la congregación (1729.33), a quien Feijoo dedica la "Ilustración apologética al primero y segundo tomo del Theatro Crítico» y Sarmiento su "Demonstración crítico-apologética de el Theatro Crítico Universal». Fue autor de las célebres "Antigüedades de España), dos tomos en folio (Madrid 1719).

44 P. Baltasar Sáenz de Vitoria, maestro general desde 1733. Su nombre aparece firmando la aprobación del tomo VII del Theatro.

43 No está clara la primera letra de este apellido: parece más bien una B; pero quizá podría ser una $\mathrm{P}$ y en este caso habriamos de leer Polanco. 
Pees.

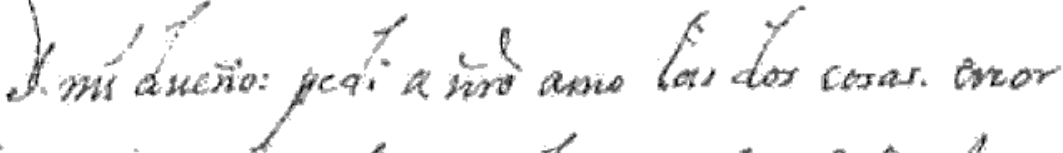

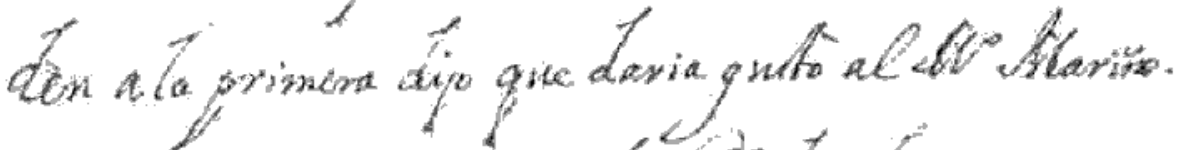

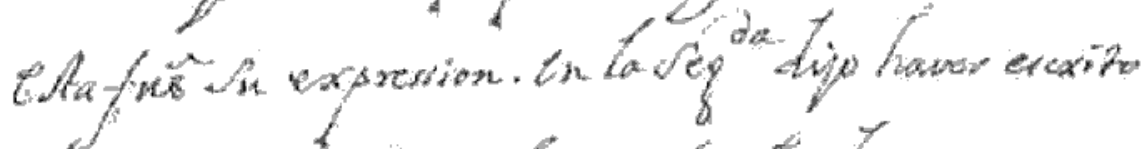

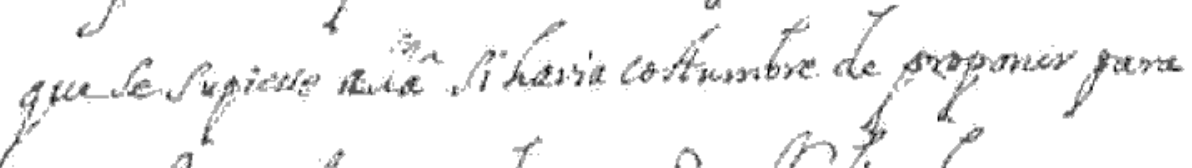

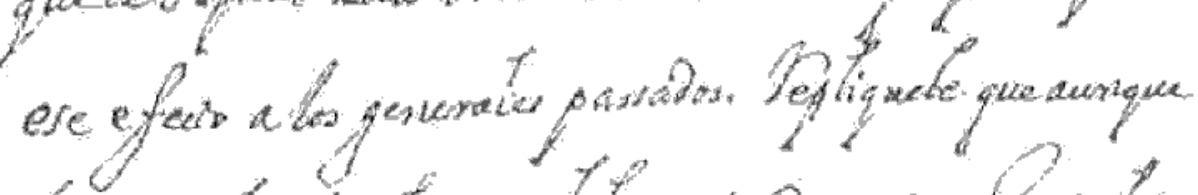

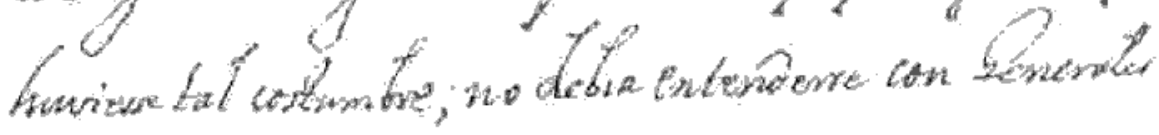

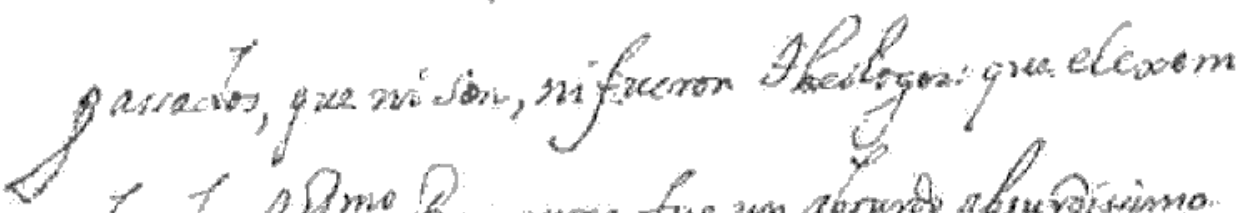

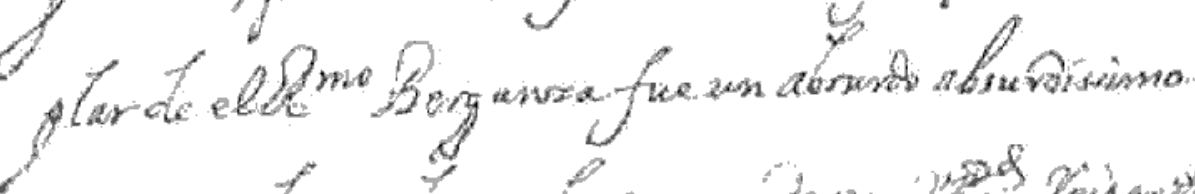

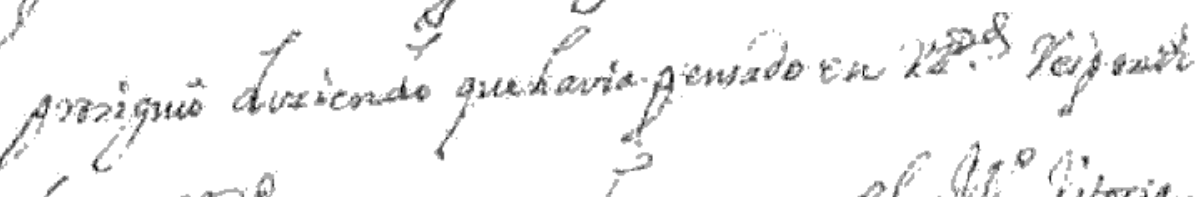

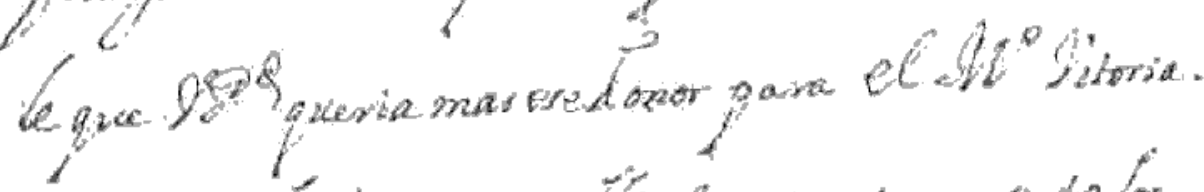

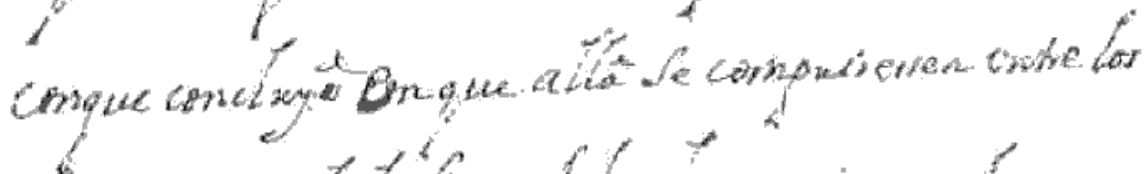

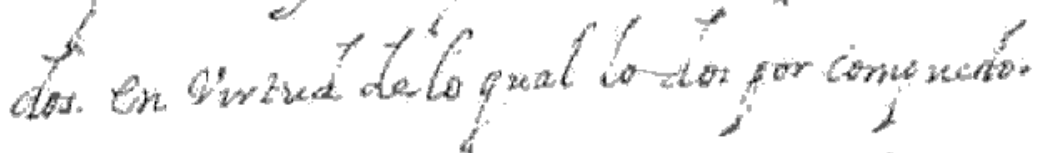

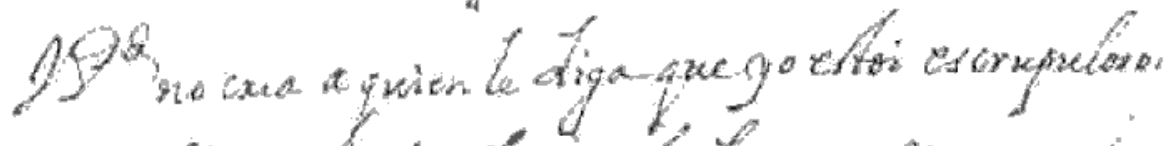
whatasicmos bo dos un bebistimo rato, veria

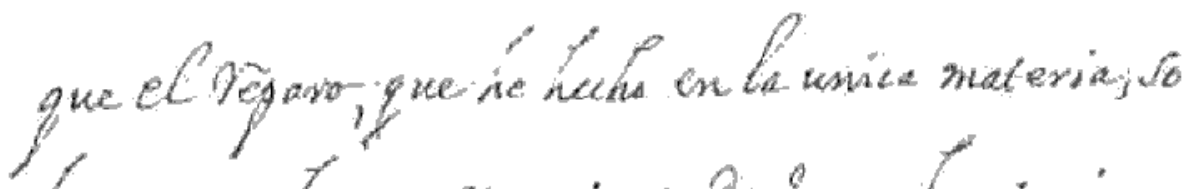

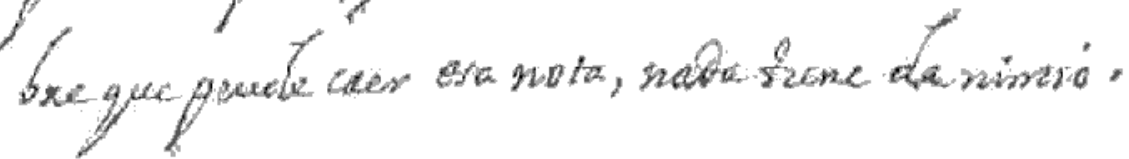


$\infty$

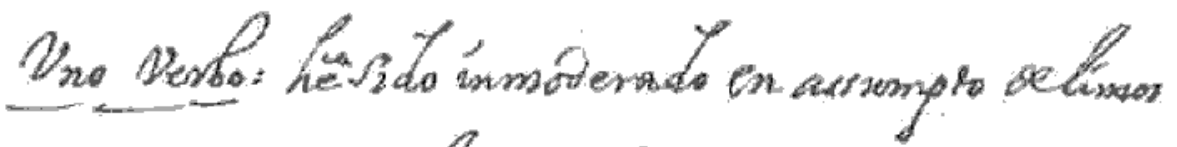

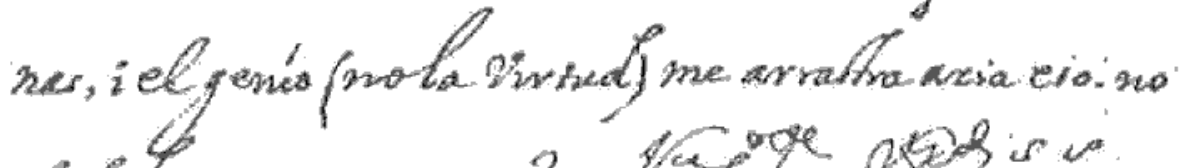

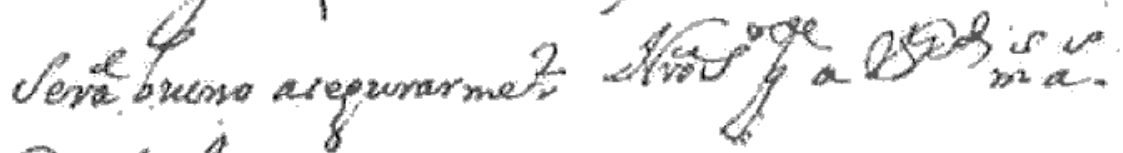

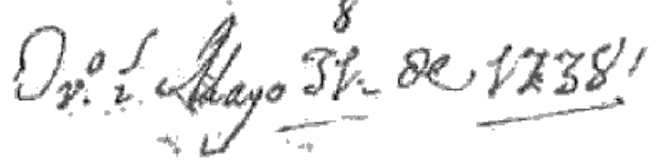

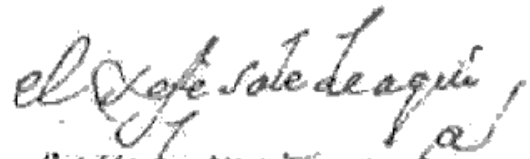
parsico mairema a Conctiona

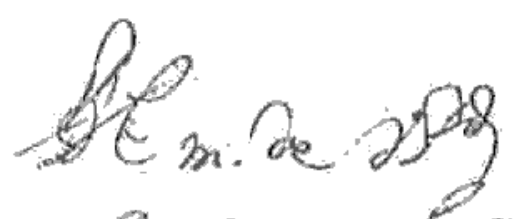
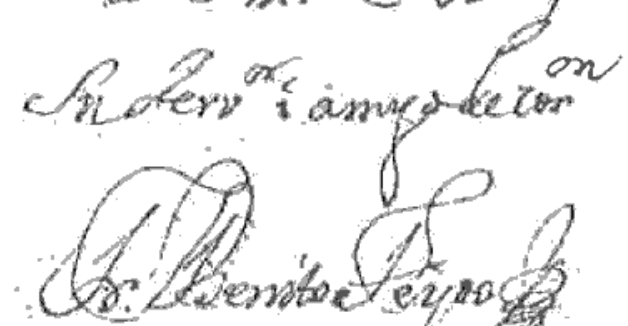

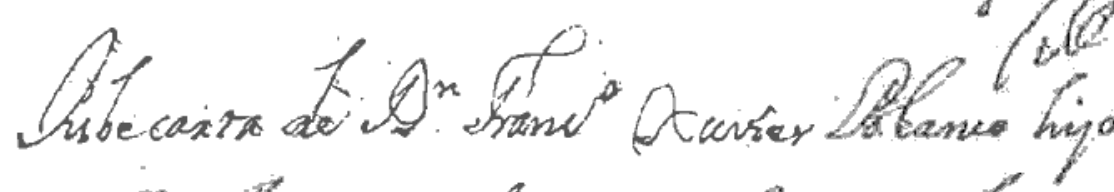

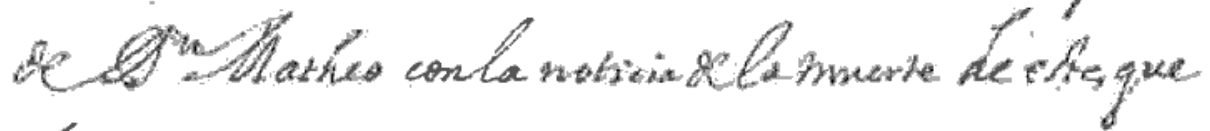

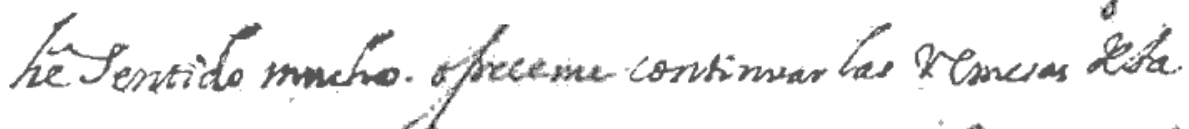

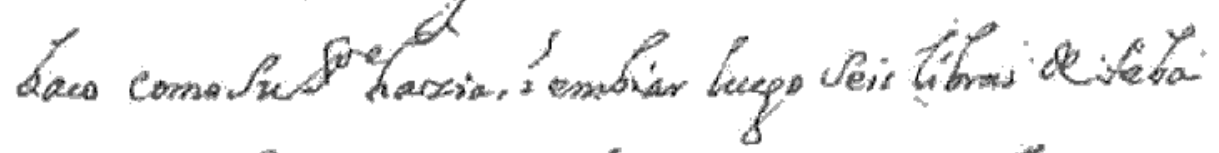

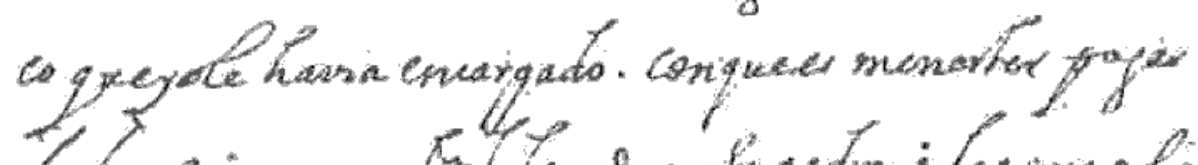

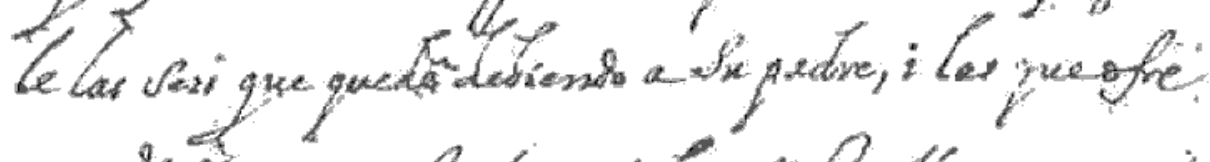

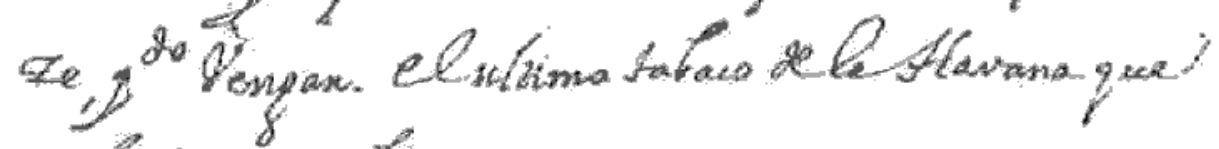
combis Oorged, es rapisrima cona.

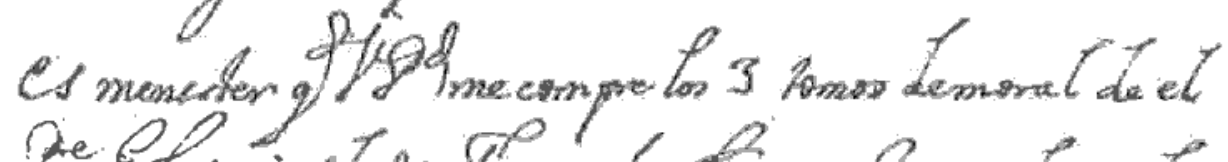

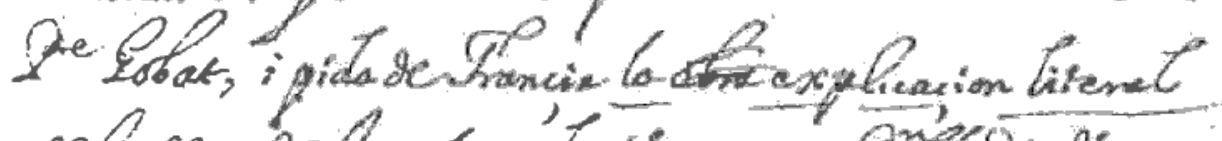

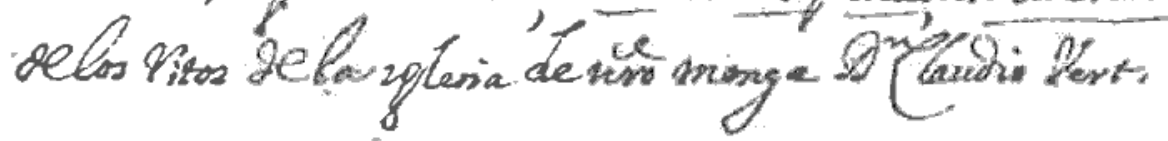


[Nota marginal: $]$ El xefe ${ }^{46}$ sale de aquí passado mañana para Cornellana.

1739, junio, 27. Oviedo

SObRe la potestad de los exorcistas. pide textos de los santos padres y docTORES QUE PRUEBEN LA INUTILIDAD DE LA FILOSOFIA PARA EXPlicar LOS MiSTERIOS DE LA FE.

AMS, carp. C. 1, núm. 6. Original autógrafa.

Cita: G. Marañón, o. c., 142; - G. Delpy, o. c., 280 y $385,1 .{ }^{*}$ col.

Padre nuestro, amigo i señor: Siento la muerte de Campo por vuestra paternidad i por él, i también la de el abad de Vibanco, supuesto que, en vez de incomodarnos, nos favoreçía. Tube este correo un fray Marcos Rubiños con algunas objeçiones (por la mayor parte ineptas) sobre el assumpto de no tener los exorçistas potestad para imperar las cosas inanimadas. Es de ese convento de la Merçed. Assí será fáçil a vuestra paternidad informarse de qué sujeto es.

Supuesto que quando llegue ésta tendrá ya vuestra paternidad sus libros colocados, puede desde luego aplicarse a buscarme autoridades de padres a de hombres señalados al assumpto de que la philosophía (o in genere, o la aristotélica) es inútil para explicar los misterios de la fee; aunque para esto más ripio havrá en la librería de la casa que en la de la çelda. La inmensa tardanza de los libros de Françia me haze mucho daño.

Nuestro Señor guarde a vuestra paternidad muchos años.

Oviedo i junio 27 de 1739.

Padre nuestro, besa la mano de vuestra paternidad su servidor i amigo de corazón,

\section{Fr. Benito Feijoo [rubricado]}

Nuestro padre maestro Sarmiento, mi amigo i señor.

46 El general al que aludimos en la nota 411 de esta carta. Después de girar la visita canónica al colegio de San Vicente de Oviedo, se disponía a hacer lo propio en San Salvador de Cornellana, sito en el municipio de Salas, en la margen izquierda del rín Narcea. 
1740, septiembre, 17. Oviedo.

SE EXCUSA DE POR QUÉ NO ESTABA DISPUESTO A ACEPTAR CARgos hoNoríficos. DUDA SOBRE SI A SUS 64 AÑos LE OBLIGABA EL PRECEPTO DE AYUNo.

AMS, carp. C 1, núm. 7. Original autógrafa.

Pub., en parte: G. Marañón, o. c., 19-20 nota 3; -P. Arias, Historza del real mo nasterio de Samos, Compostela 1950, 298-99.

Padre nuestro, amigo i señor: Cierto que me caen en graçia los conjuros que vuestra paternidad me haze para animarme a aquel acto heroico de San Martín de Turón: Domine, si adhuc populo tuo sum necessarius, non recuso laborem, olvidándose enteramente de que habla con un hombre de sesenta i quatro años, $\mathrm{i}$ de cuerpo enfermizo desde la edad de diez $\mathrm{i}$ nueve; $\mathrm{i}$ sobre esto con más lacras en el alma que en el cuerpo, cuya colección me haze no sólo innecessario, mas enteramente inútil al pueblo de Dios. No lo jurgará acasso assí vuestra paternidad i otros poeos apassionados. Pero aquí me viene lo de san Agustín, no me acuterdo en qué epistola: Non mith placel cum a charissimis meis talis iudicor qualis non sum. Mas demos el casso de que yo me hallasse con fuerzas espirituales i corporales, ¿de qué pueden servir éstas? Yo no seré sino uno de tantos. Porque este vaníssimo honor de reverendíssimo rabón [sic] no da actividad alguna. Acasso en otro genio eficaz sirviera de algo, pero en el mío es lo mismo que la carabina de Ambrosio. Pensar que esta reverendíssima pueda conmutarse en otra es para mí una insigne quimera, punto menos que la que vino de Zelorio ${ }^{47}$. [Al margen: $]$ De ésta a nadie escribí palabra sino a vuestra paternidad $\mathrm{i}$ al procurador general Vergara ${ }^{48}$.

Yo no sé quién pudo asegurar que el de la intentona de el año passado prosigue en ella. Tengo ģerteza de que, desde la inútil tentativa que hizo en la visita, enteramente abandonó la pretensión.

47 Monasterio de San Salvador de Celorio, perteneciente al partido judicial y ayuntamiento de Llanes (\$sturias). Era colegio de artes de la congregación de Valladolid.

48 P. Sebastián de Vergara, a quien nos hemos referido ya en la nota 40 de la carta 4. Después de haber ejercido el cargo de visitador de la congregación (1733-37), fue elegido para el de procurador general (1737-41). Había sido abad de Silos (1721-25), su casa de profesión, y, en el cuatrienio 1729-33, de San Martín de Madrid. De este monasterio volvería a ser alad desde 1745 hasta 1748 , año en que murió. Fue autor de una vida de Sto. Domingo de Silos (Madrid 1736). 

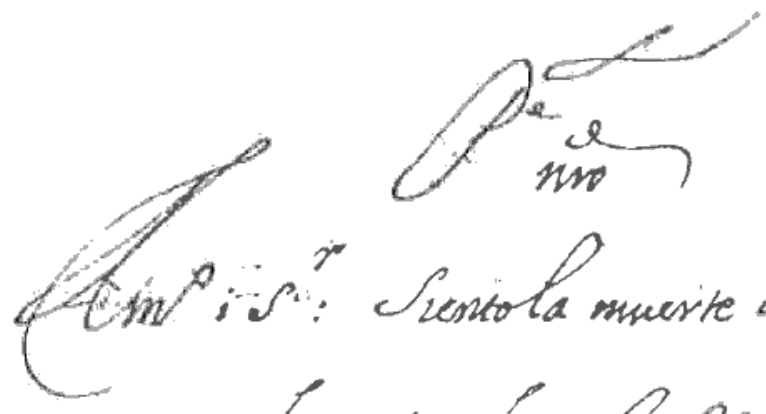

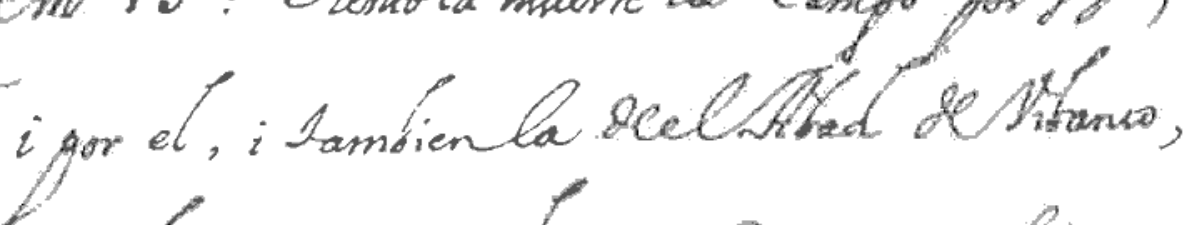

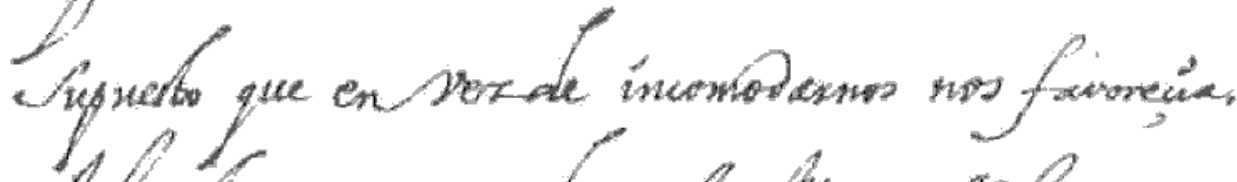

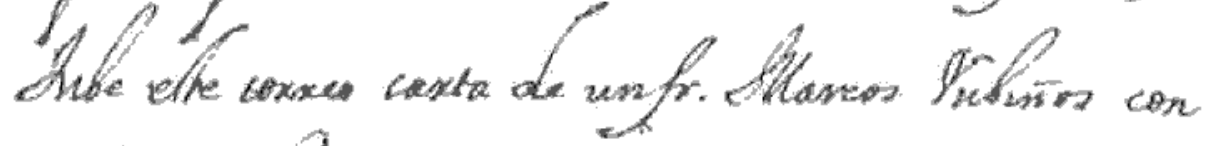

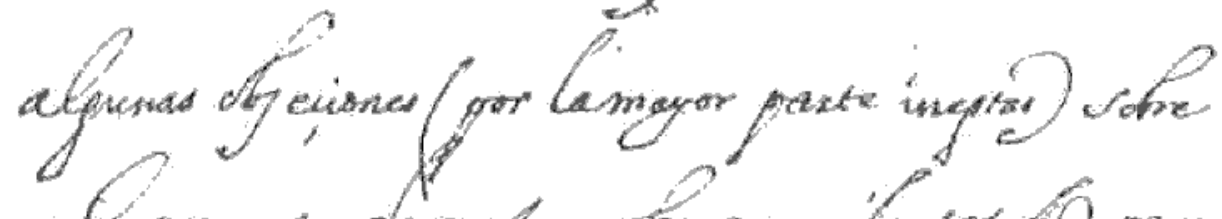

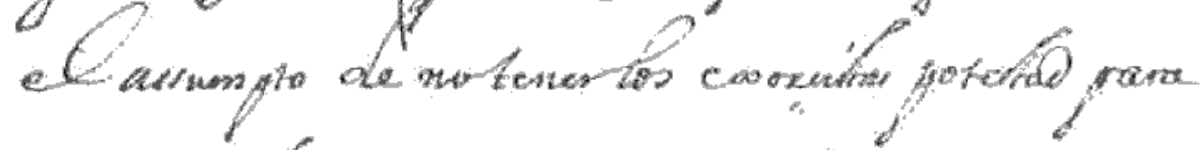

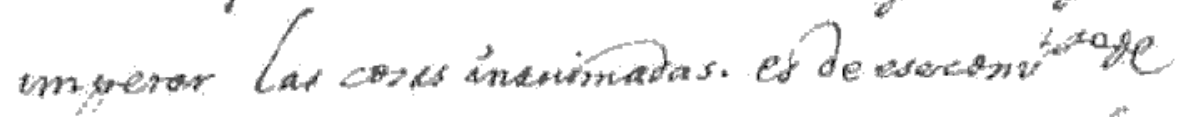

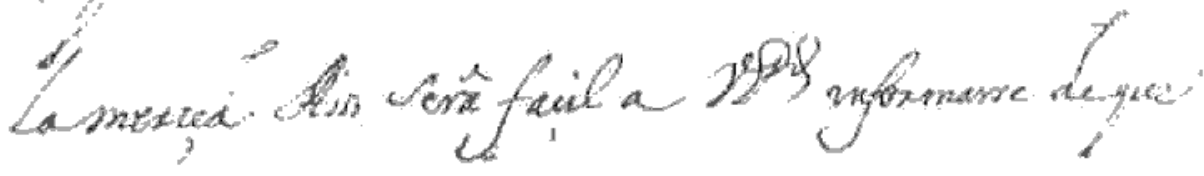

Suptoror.

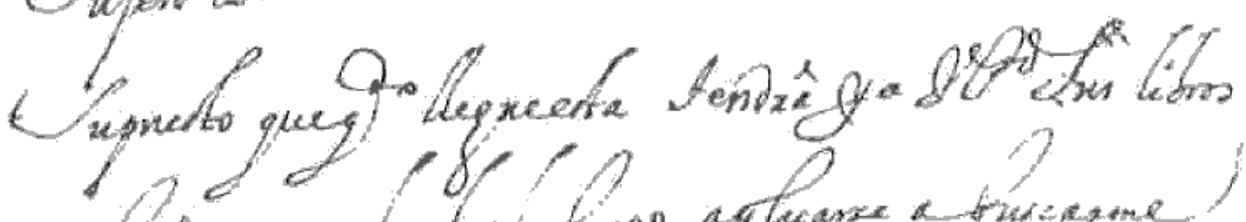

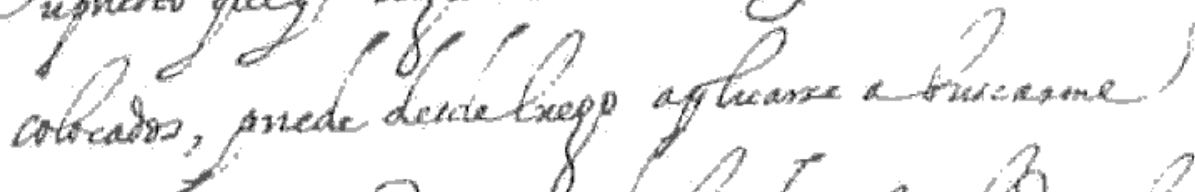

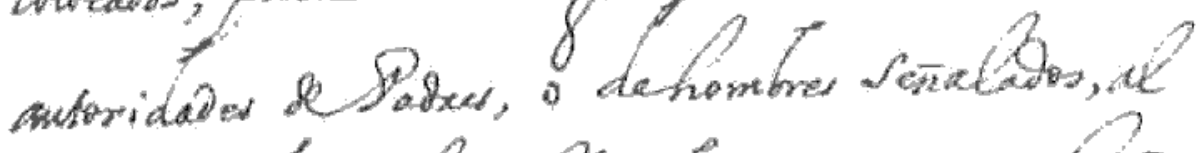

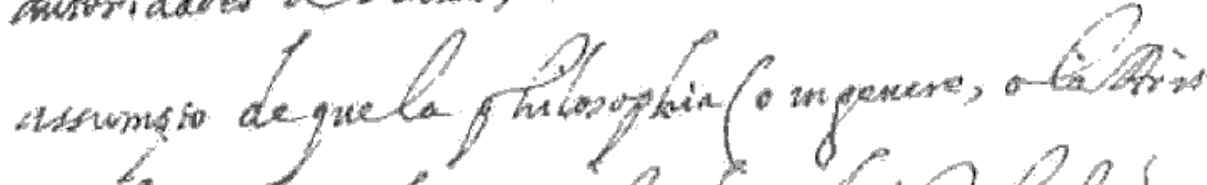

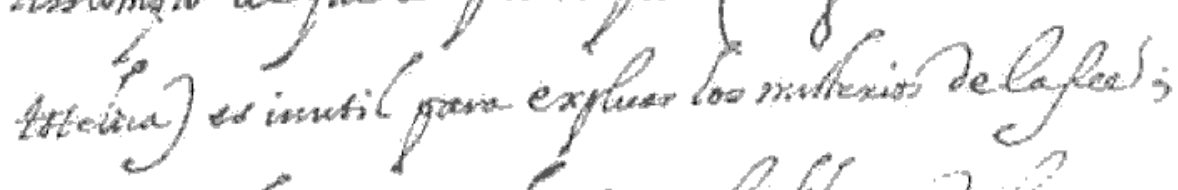

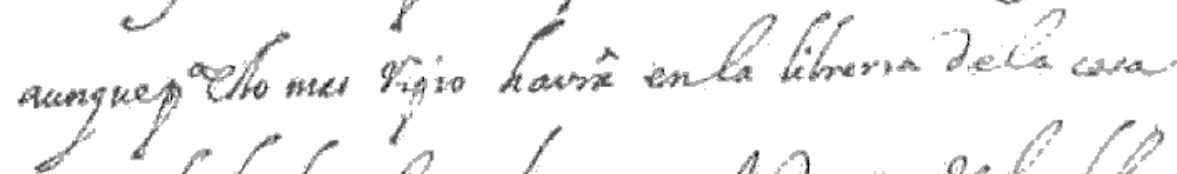

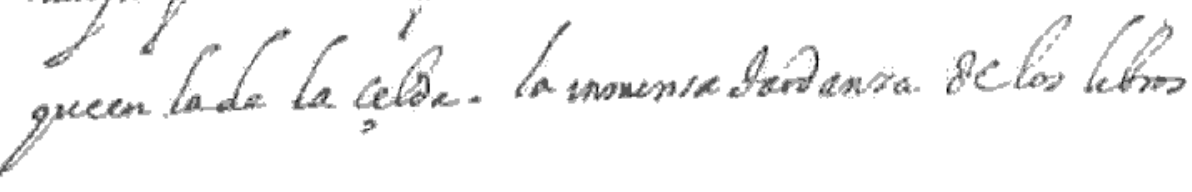




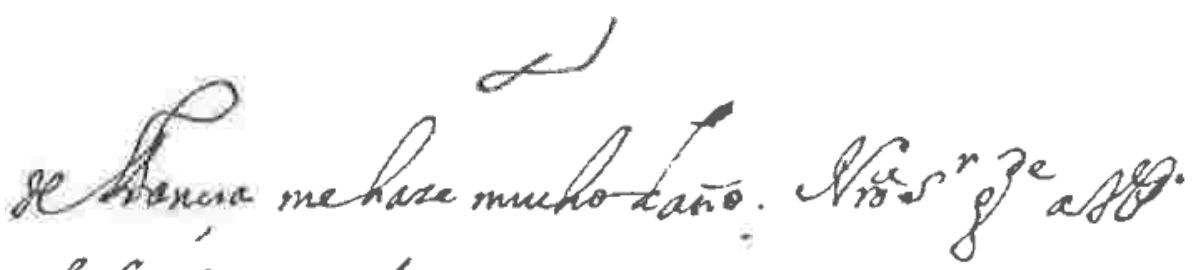
mis. Or.i tumio 27. Setr39

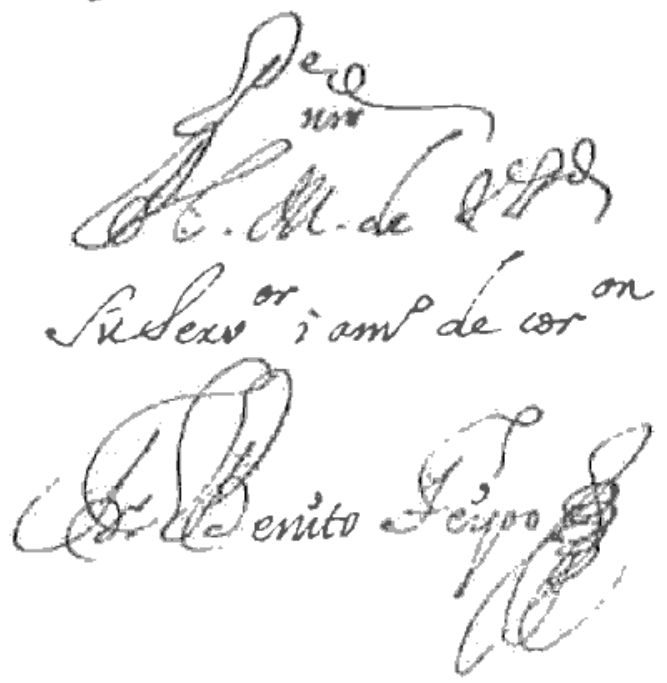

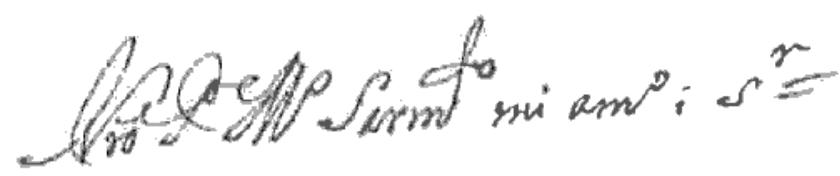



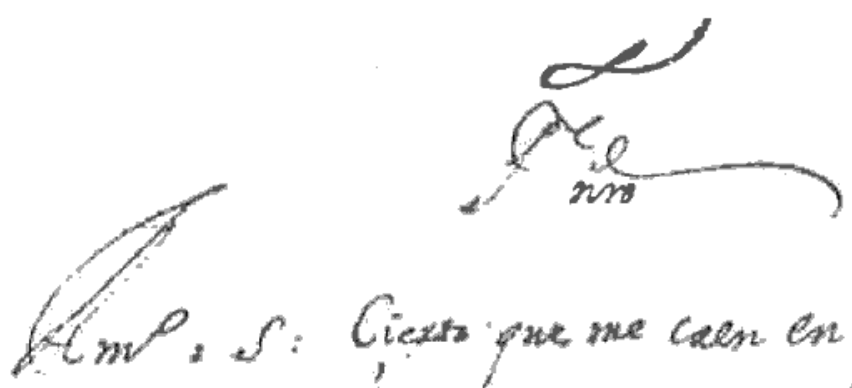

fim : S: Ciets que me caen en pracia tor compons

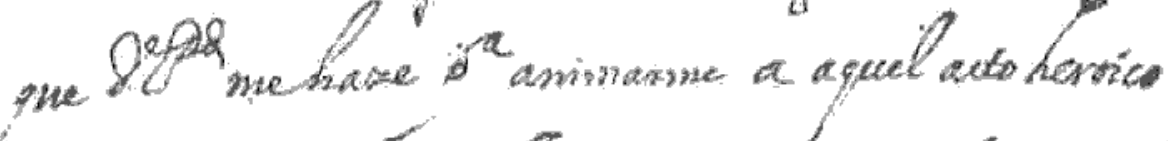

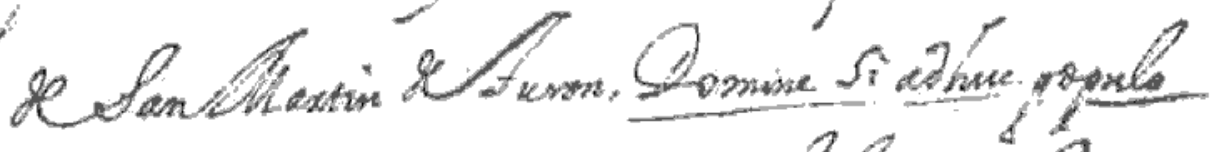

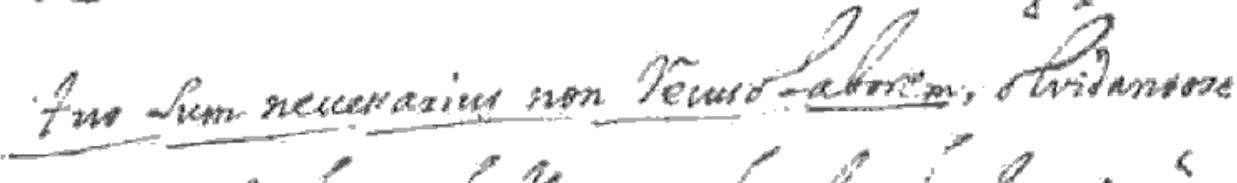
enteram de que hatio con us homone de descosta 2

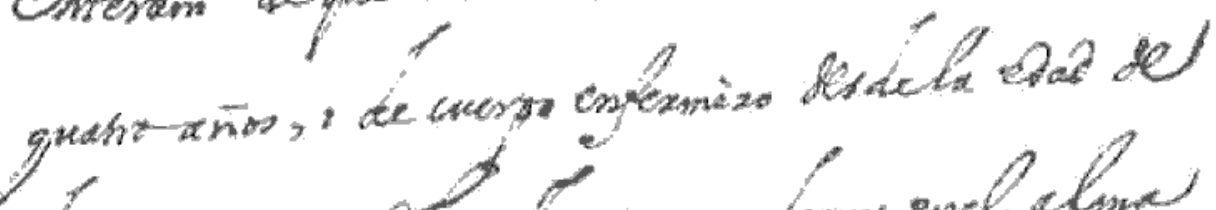

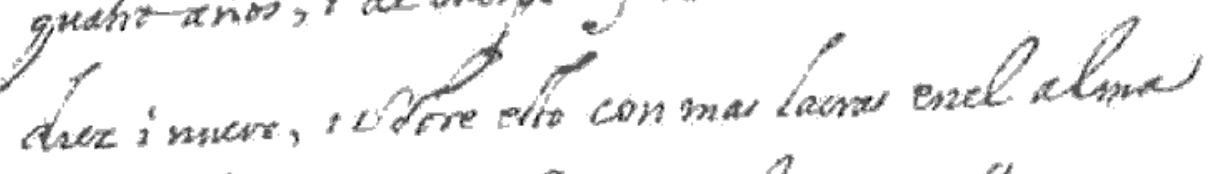

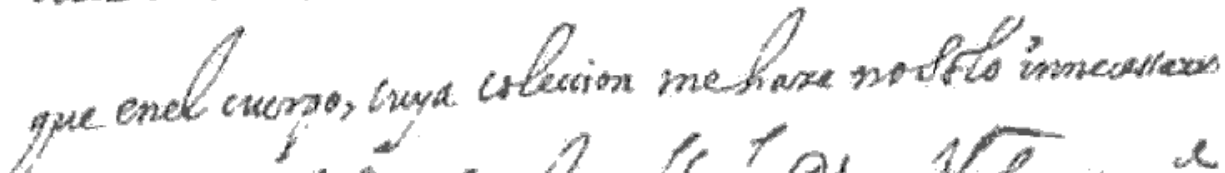

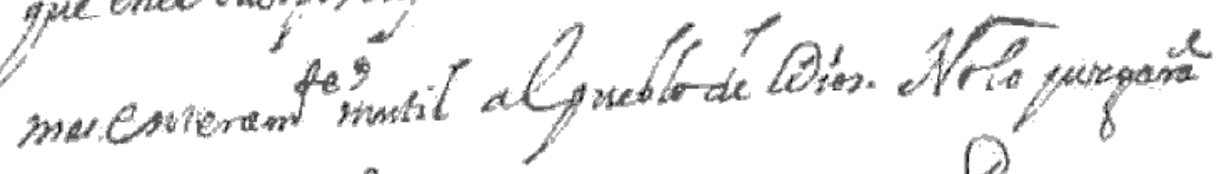

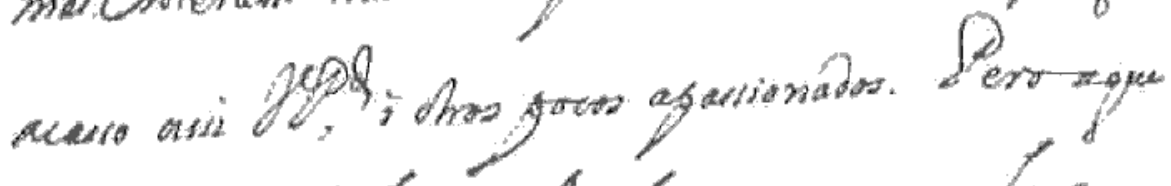

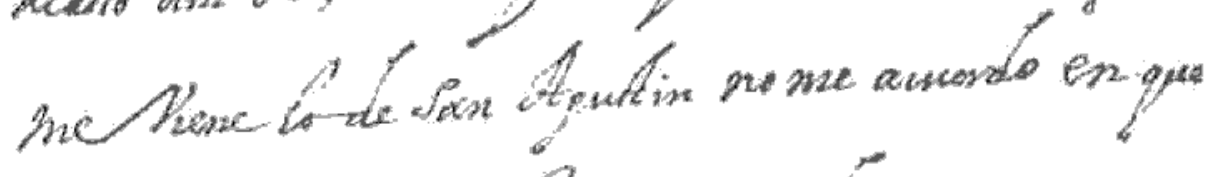
equtha, non mini glacet cusn a charissims meir

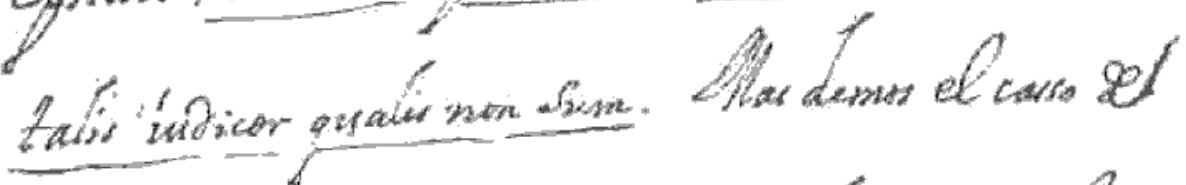

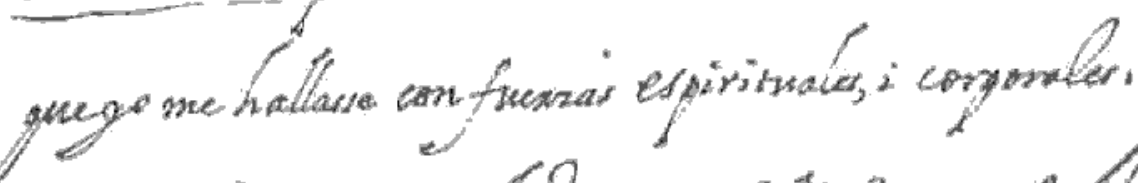

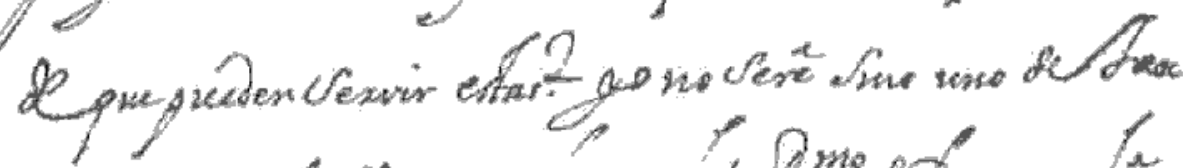

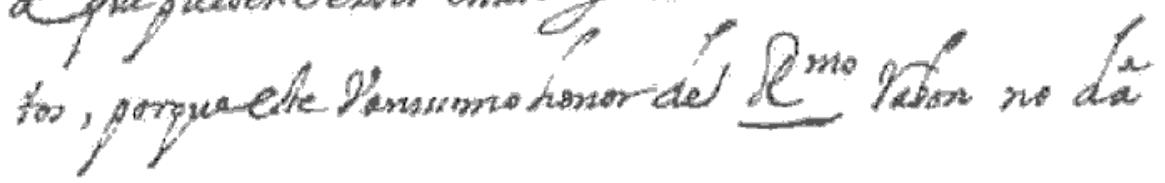




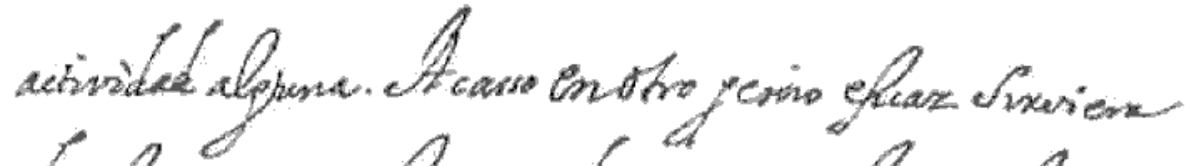

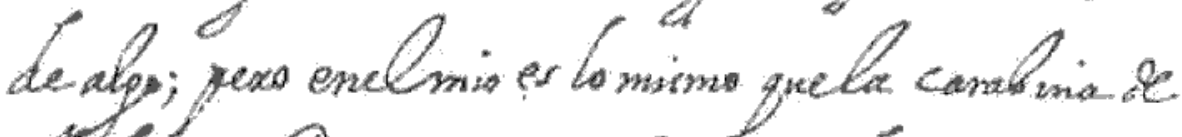

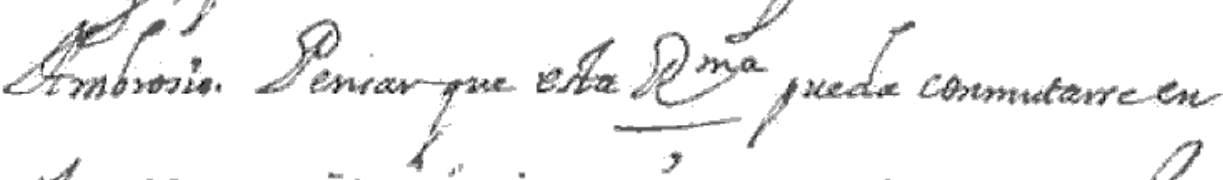

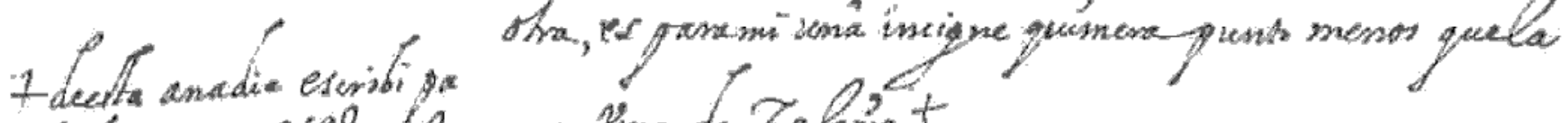

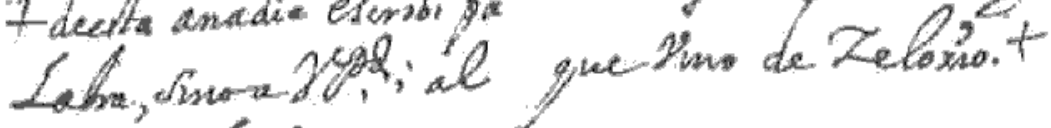
Proc or fleopera.

A

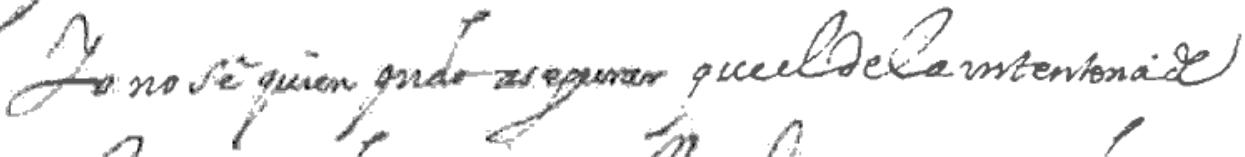

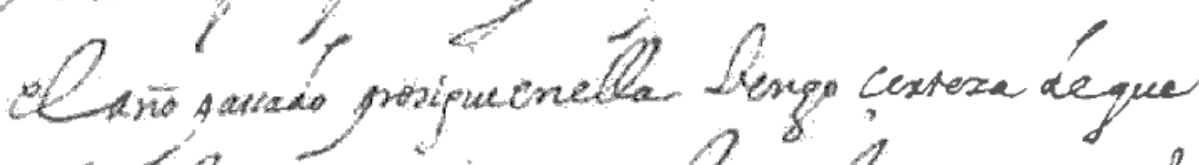

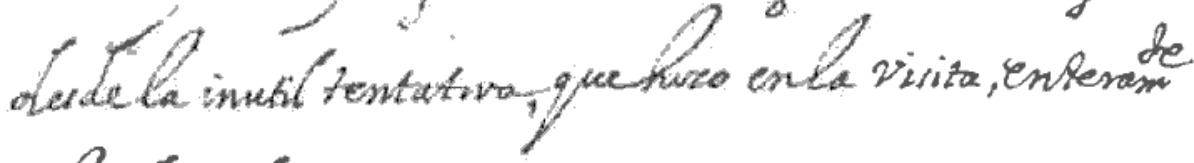
Candono tá pretersion.

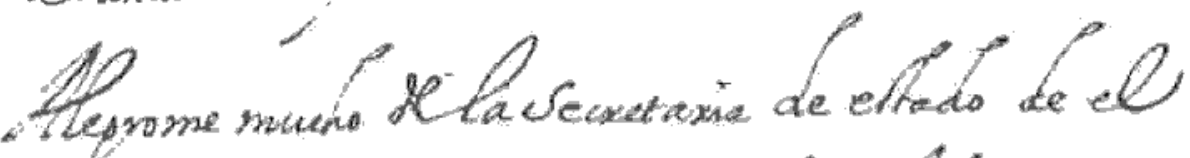
Ho $P$ P $P$ t

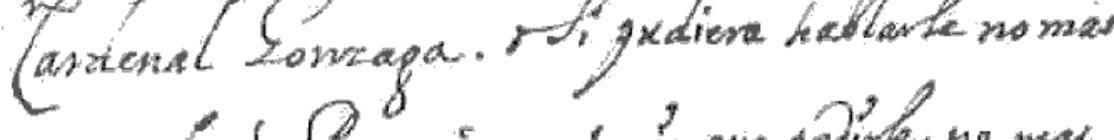

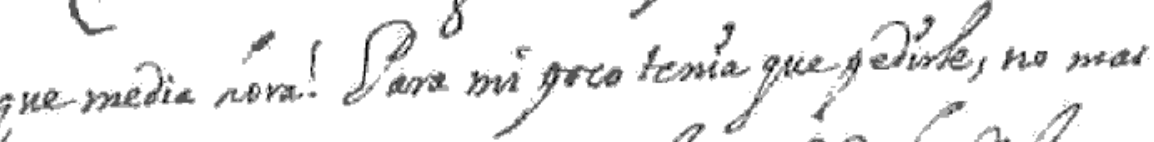

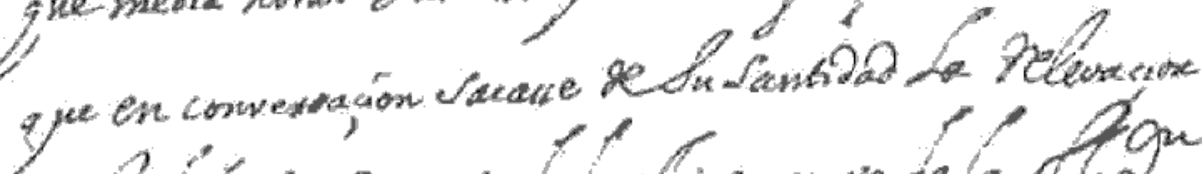

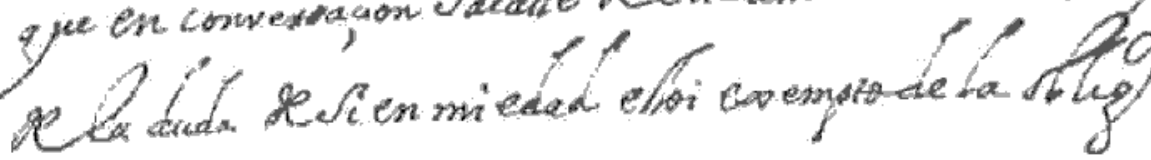
Leyuner.

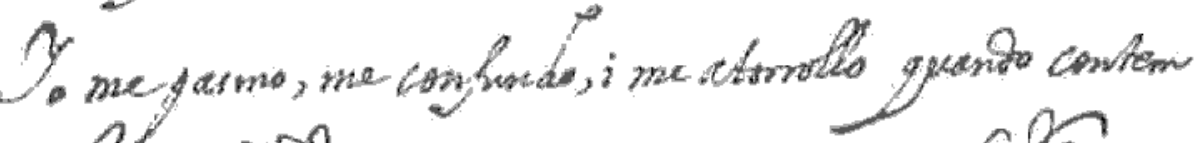

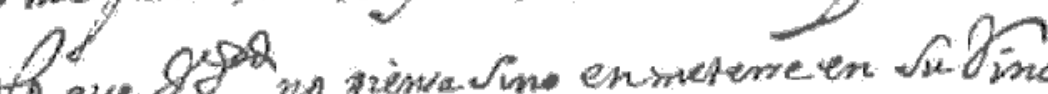

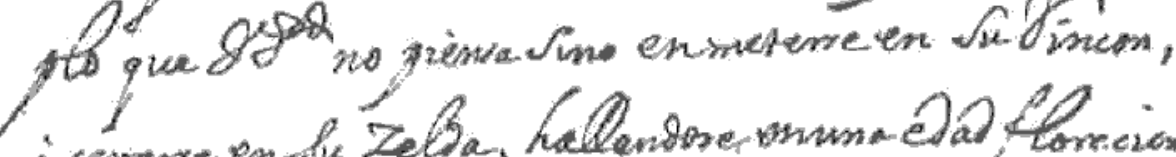

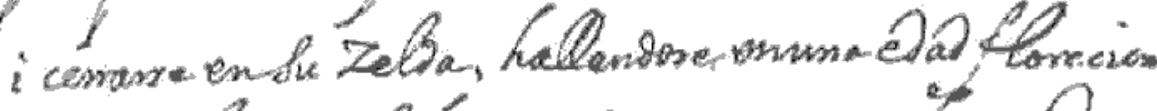

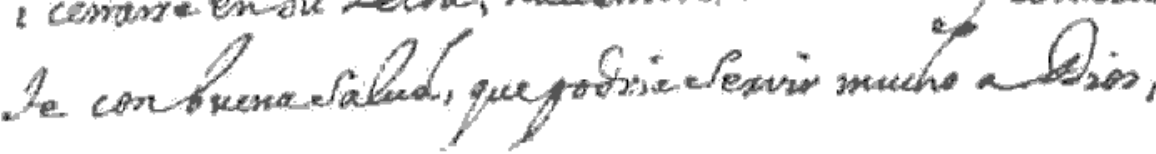



Alégrome mucho de la secretaría de estado de el señor cardenal Gonzaga ${ }^{49}$. $\mathrm{O}$, si pudiera hablarle no más que media hora! Para mí poco tenía que pedirle: no más que en conversaçión sacasse de su santidad la relevaçión de la duda de si en mi edad estoi exempto de la obligaçión de ayunar.

Yo me pasmo, me confundo i me atorrollo quando contemplo que vuestra paternidad no piensa sino en meterse en su rincón i cerrarse en su zelda, hallándose en una edad floreciente con buena salud, que podría servir mucho a Dios i al mundo, i por otra parte mucha bulla porque el vejestorio Feijoo quiere vivir para sí lo poco que le resta de vivir. ¿Ai paciençia para esto?

Nuestro Señor guarde a vuestra paternidad muchos años.

Oviedo i setiembre 17 de 1740 .

Padre nuestro, besa la mano de vuestra paternidad su servidor i amigo de corazón,

\section{Fr. Benito Feijoo [rubricado]}

Nuestro padre maestro Sarmiento, mi amigo i señor.

1741, octubre, 21. Oviedo

ENVÍA A SU CORRESPONSAL UN MICROSCOPIO Y LE DA NORMAS SOBRE SU USO.

AMS, carp. C 1, núm. 8. Original autógrafa.

Pub.: G. Marañón, o. c., parte en p. 61 y parte en pp. 301-302. Notemos, de paso, que en la nota 1 de las citadas páginas pone: $\sin$ año; sin embargo, en la carta original está claro el año de 1741. Adviértase que Marañón no utilizó los originales de estas cartas, sino la copia que de las mismas le fue enviada desde Samos: por cierto que en dicha copia no aparece el año, sin duda por no haber sabido interpretarse su lectura.

Cita: G. Delpy, o. c., $155-56$ y $364,1$. col.

49 Sixto Valenti Gonzaga, nacido en Mantua el año 1690. Fue nuncio en Bruselas y en Madrid bajo el pontificado de Clemente XII, quien le otorgó la púrpura cardenalicia en 1738. Benedicto XIV lo nombró secretario de estado en 1740, cargo que desempeñó hasta su muerte en 1756. EI P. Sarmiento le dedicó su obra Memorias para la historia de la poesia y poetus españoles. 
Padre nuestro, amigo i señor: Allá va la comissión que acaba de remitirme nuestro padre general. A quien dan, no escoge. Las ochenta missas ya corren desde mañana por quenta de todos los saçerdotes que ay aquí obligados a las de la casa. Dentro de dos o tres días saldrá de aquí un colegial hijo de Monserrate de Cataluña para Monserrate de Madrid; éste llevará el Marco Antonio ${ }_{\text {Mureto }}{ }^{50} \mathrm{i}$, agregado a él, un microscopio que dos años ha se compró por encargo mío a un judio de Amsterdan en 350 reales, i pedía pienso que hasta quatroçientos; pero respondiéndole el deán de esta iglesia (quien, en compañía de don Joaquín de Velarde i de don Clemente Duque, hizo por aquel tiempo viaje a París i a Olanda) que yo no havía dado más dinero para la compra que los 350 , lo que era verdad, le alargó con la condición de que yo le embiasse el tomo $8^{\circ}$ i $9^{\circ}$ de el Theatro Crítico. El demonio de el judiazo tenía los siete primeros, en compañía de todas las obras de el padre Vieira ${ }^{51}$. Era, o es, oriundo de Portugal.

Yo no tengo paciençia para andar atisbando átomos, y assí remito el microscopio para que vuestra paternidad los atisbe, si quisiere, o haga de ese armatoste lo que se le antojare. Por si vuestra paternidad no huviere visto otro de ese género, advierto que vienen a ser no uno, sino seis microscopios, esto es, aquellas rodajitas con un vidro menudíssimo en el centro i cubiertas con su monterilla. Quanto es más pequeño el vidro, descubre objetos más menudos; i assí se verían los microscopios colocándolos enroscados en la cabeza del tubo a proporçión de el tamaño de los objetos que se quieren examinar, i el objeto, acomodado en un vidro de qualquiera de las tablillas, se emboca por la abertura que está pocas líneas debajo de la cabeza de el tubo. Toda esa baratija de instrumento descubrirán a poca reflexión su usso respectivo. En el secreto van unos niveles de la nueva invençión.

Al passo que me deshago de este instrumento óptico que no me sirve, deseo otro que me es necessario, esto es, antojos [sic] proporçionados a mi vista. Pero, para hallarlos, es menester explicarme yo primero sobre la materia. El defecto de mi vista es de cansada. Ai, para remediar este defecto, antojos de determinada espeçie, a distinción de los que llaman de grados.

50 Marco Antonio Mureto (1526-85). Humanista francés, autor de Pöemata varia, Sententiae graecae, Variae lectiones y algunas obras más. Su Opera omnia se editó por vez primera en Verona el año 1727. Es probable sea ésta a la que aquí alude Feijoo,

51 P. Antonio de Vieira, jesuita portugués, predicador notable, diplomático y celoso misionero en el Brasil durante varios años. Nació en Lisboa en 1608 y murió en Brasil el año 1697. Sus sermones fueron publicados en 15 vols. entre los años 1679-99. 
Pero en la fábrica de estos mismos antojos ay mucha variedad. Unos hazen la letra mucho mayor que otros, i a proporción que la vista se va gastando más i más, se van necessitando differentes antojos, que vayan haziendo mayor i mayor la letra; i en la misma proporêión van permitiendo que acerquen más i más los ojos al libro. De modo que los primeros antojos de que ussé me representaban la letra con bastante magnitud $i$ me permitían tener los ojos en la distançia de una terçia de la plana; pero estos mismos, dentro de cinco años poco más o menos, me representaban la letra mui menuda i también confusissima si no apartaba los ojos a más de media vara, en cuya distançia la letra siempre quedaba pequeña, pero clara; i el día de oi de ningún modo puedo leer con ellos. De el mismo modo los que empezé a ussar quando los primeros me eran de un usso diffícil, aunque oi me sirven, pero no tan bien, porque successivamente me obligan a apartar Ios ojos más $i$ más de el papel i cada día me muestran la letra algo menor. Ho oído que en las oficinas o tiendas donde se venden antojos de vista cansada ay su distribuçión de classes, de modo que los ay i nombran de sexagenarios, septuagenarios, etc. Si por esta regla se huviessen de comprar para mí en el estado presente, se deberían pedir de septuagenarios. Pero acasso esta regla es mui falible, i me pareze mucho más segura comprar los que, entre todos los que ay de venta, aquellos que a un hombre de vista mui eansada representen la letra de mayor magnitud $i$ con que pueda leer a la más corla distançia de el libro. Esto aún no corre tanta priessa que no podamos hablar más sobre la materia antes de passar a la compra o al encargo.

Oviedo i otubre 21 de 1741.

Besa la mano de vuestra paternidad.

\section{Feijoo [rubricado]}

Nuestro padre maestro Sarmiento, mi amigo i señor.

1741, octubre, 28. Oviedo

PIDE El ENVío de unos anteojos lo VISTA CANSADA O DE PIÉsBita.

AMS, carp. 1, núm. 9. Original autógrafa.

Pub.: G. Marañón, o. c., 300-301. Adviértase que, al igual que en la carta anterior, en la nota 1 de la p. 301 pone: $\sin$ año; empero en la carta original sstá claro el 


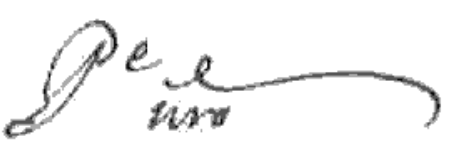

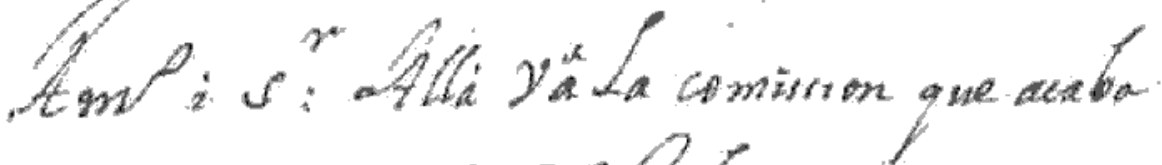
Hemizirme ino pelenta atien dan no

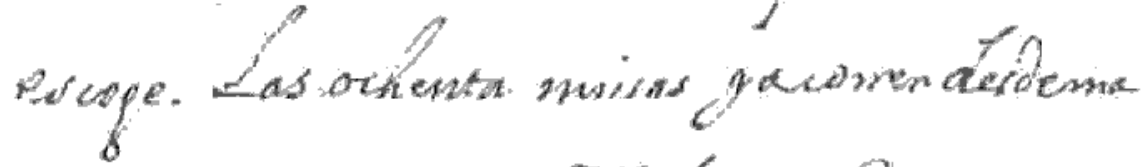

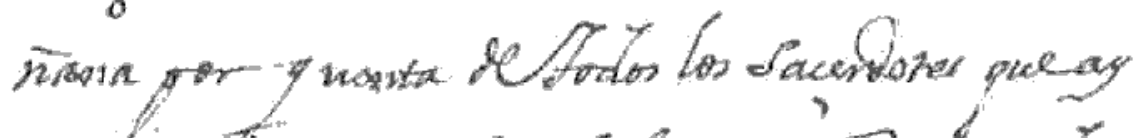

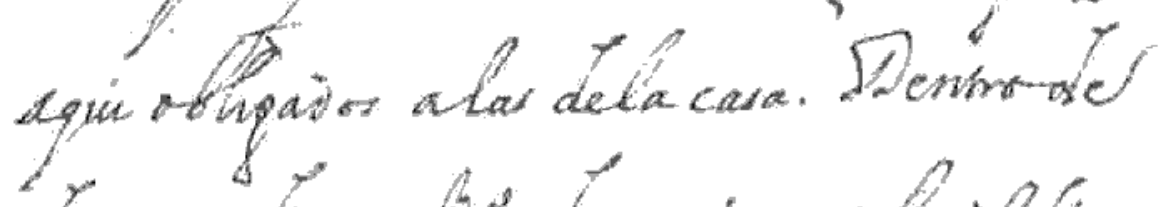

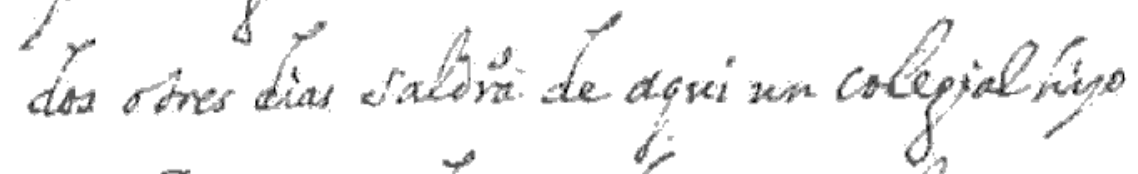

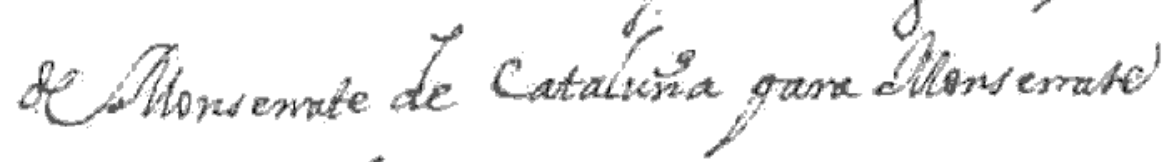

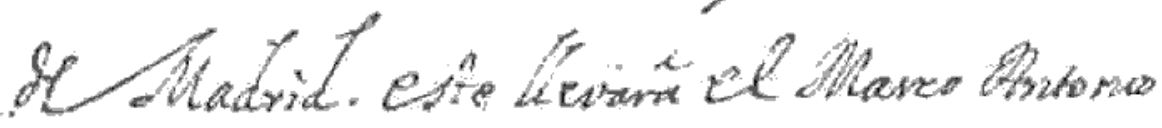

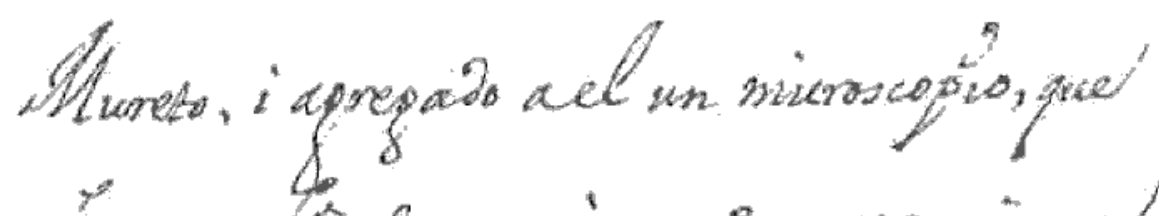

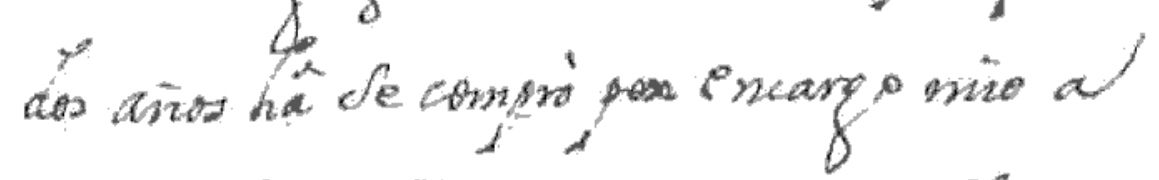

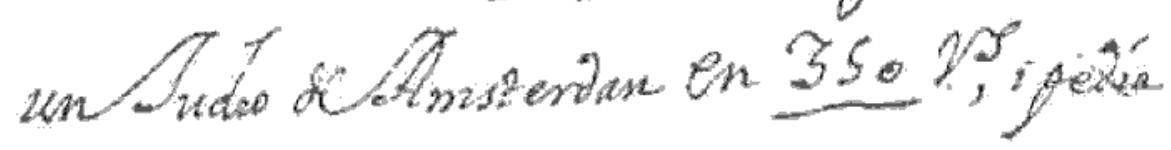

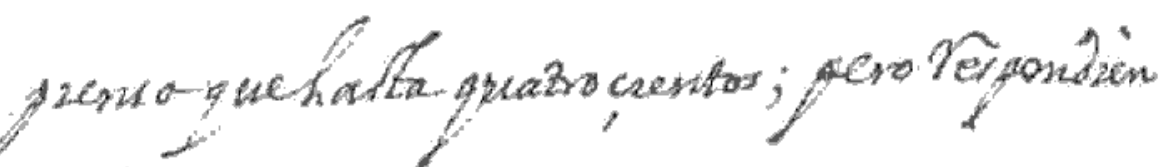

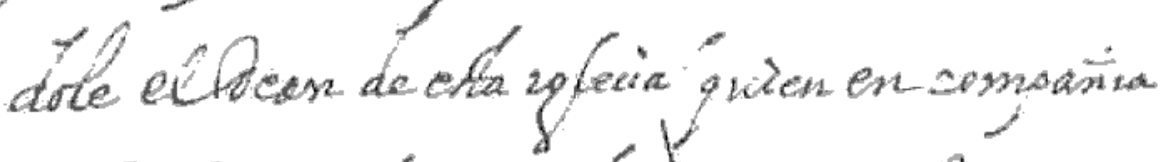

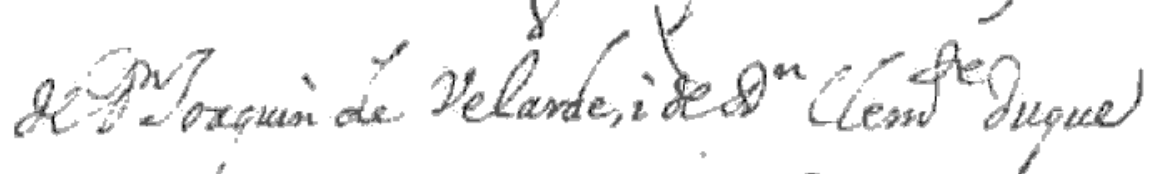

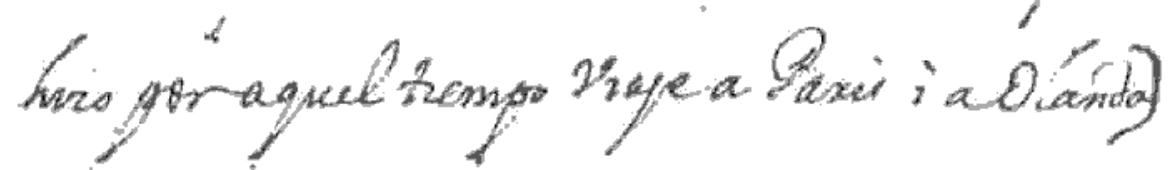




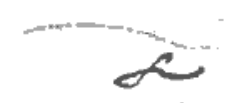

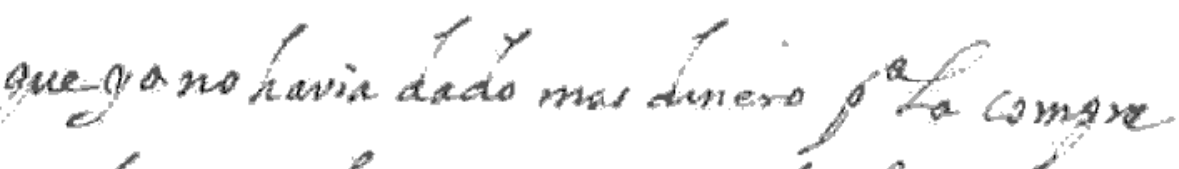

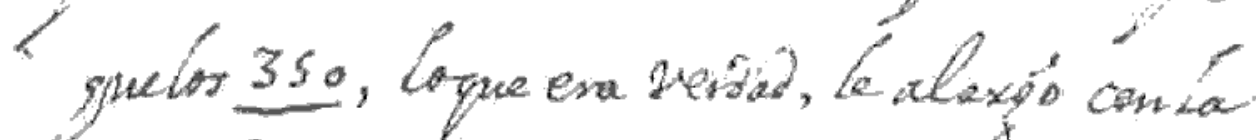

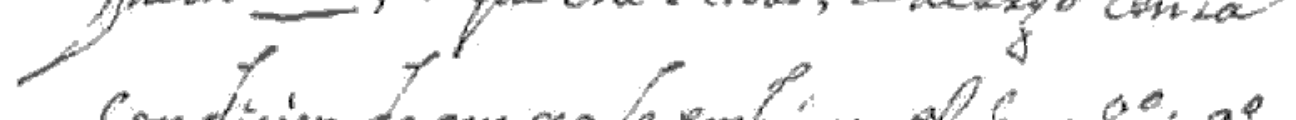

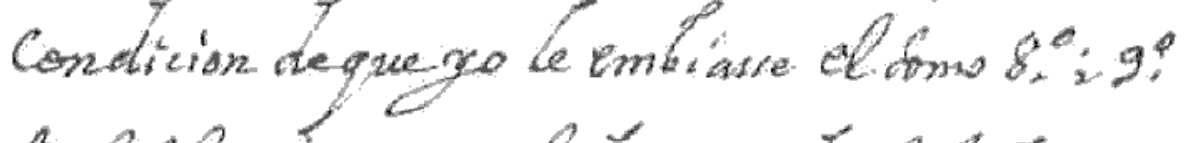

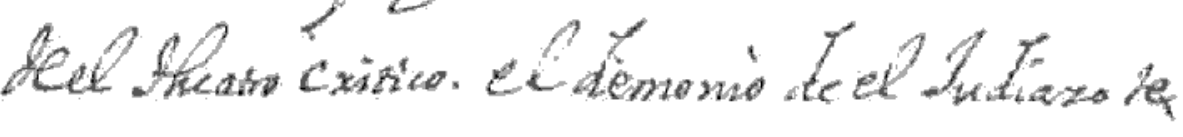

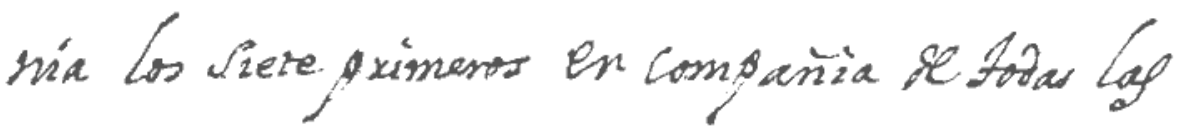

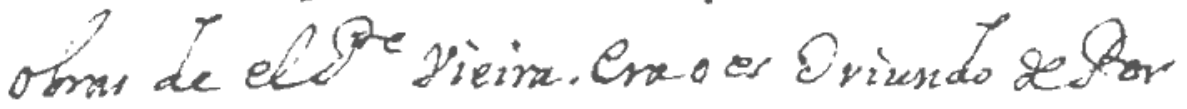
tupal.

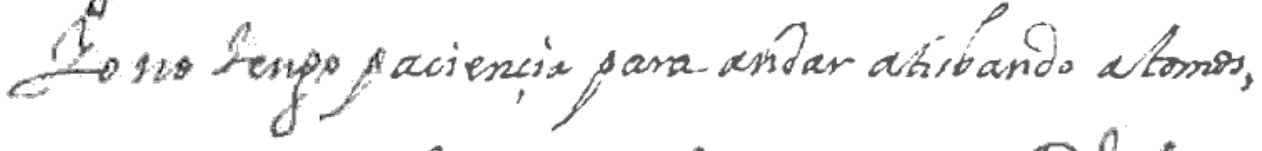

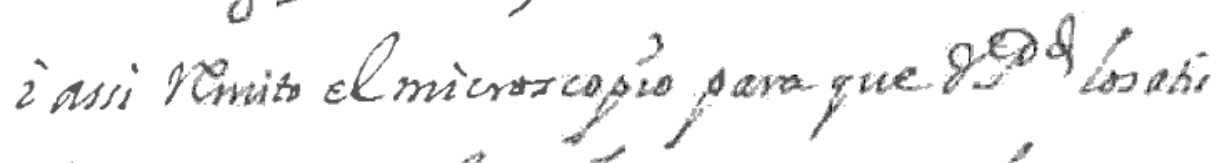
se piowiviere, thapa de ese drmatare lo quede

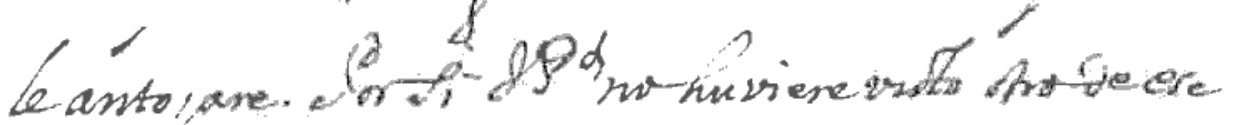
$<$

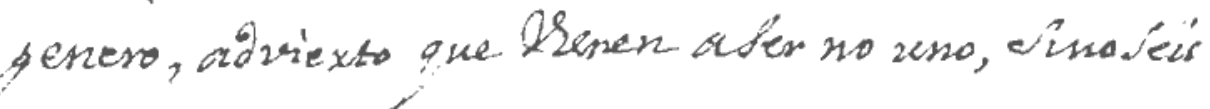

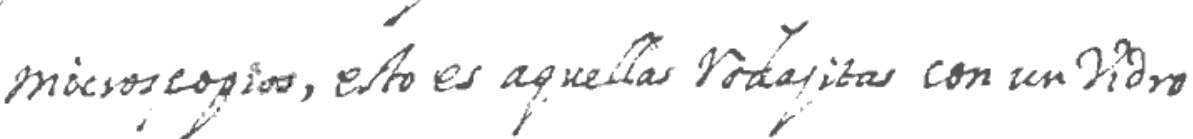
inemuatisimo end centro icubuertas consin monte

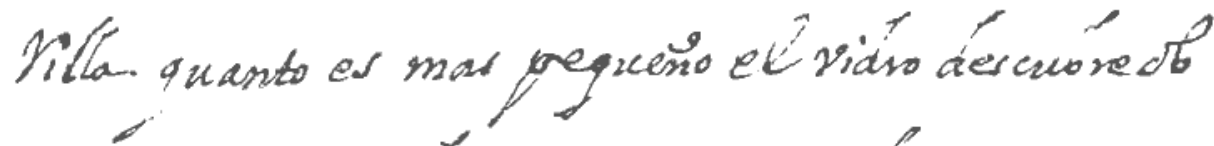

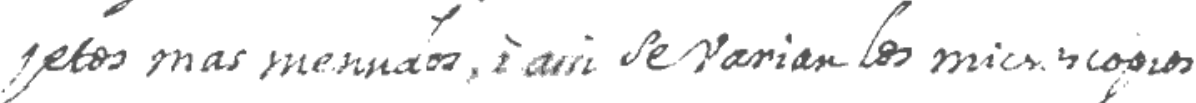
colocandolos enrosados enta cabra dectabo a 
$\alpha$

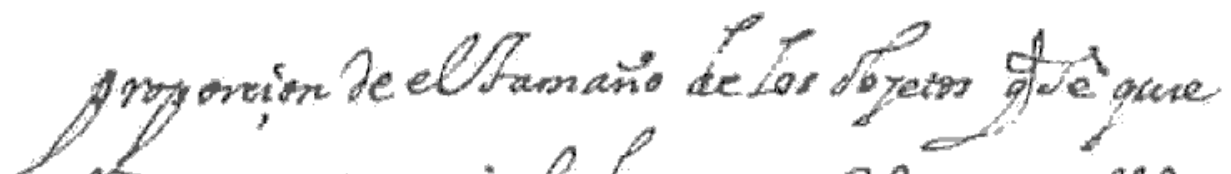

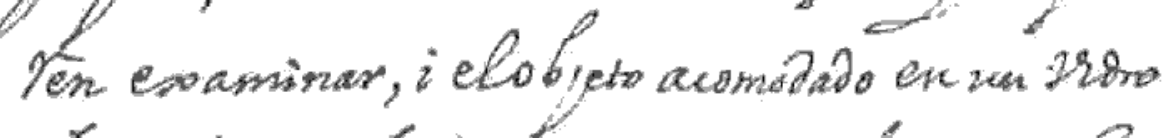
de qualquicina de las hablitas ve embora or ta

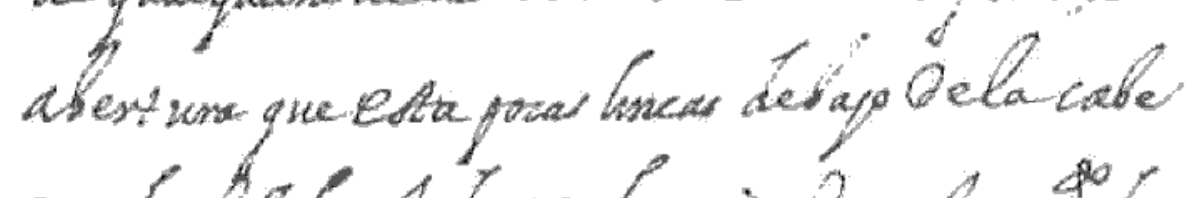

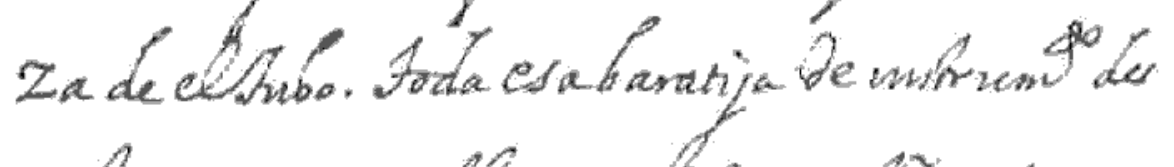

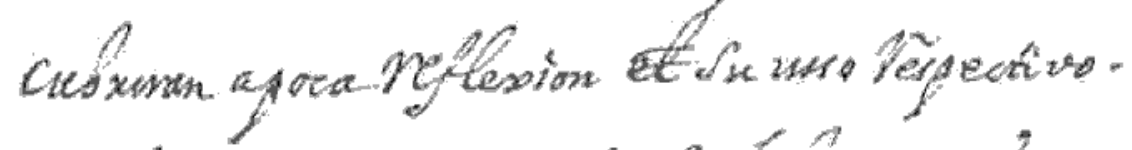

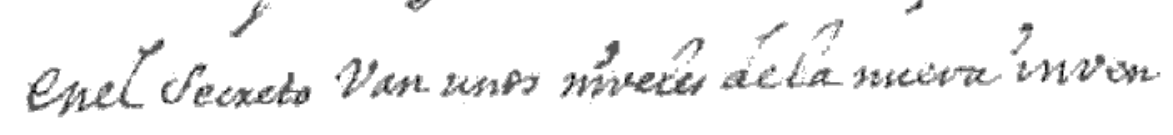
cion.

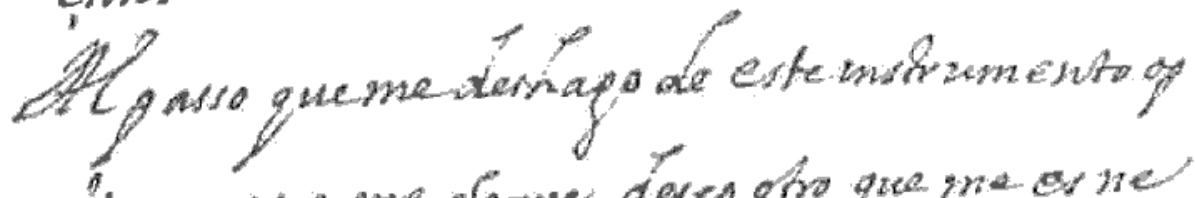
tico que no me-desve, deres oto que me ov ne

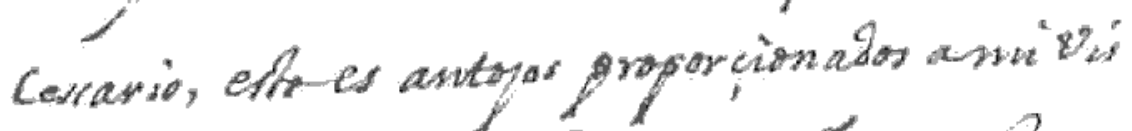

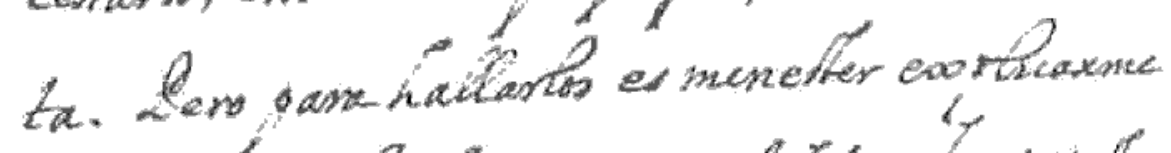

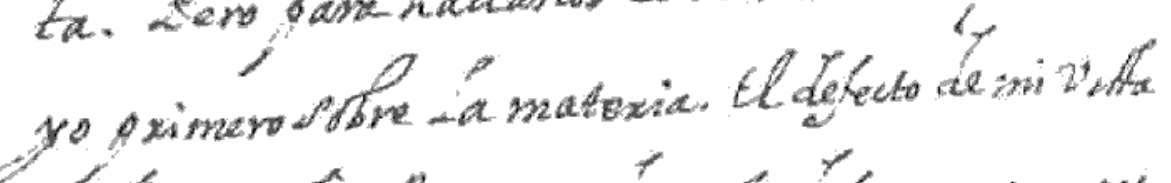

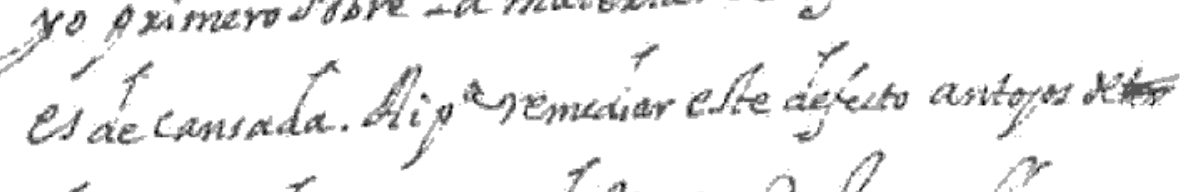
dotexminata especie a dustisnsion delos quetioman

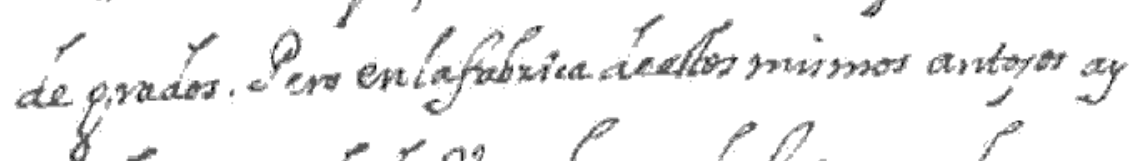
mucha variedad. 2900 hanen La betra mucho mayor

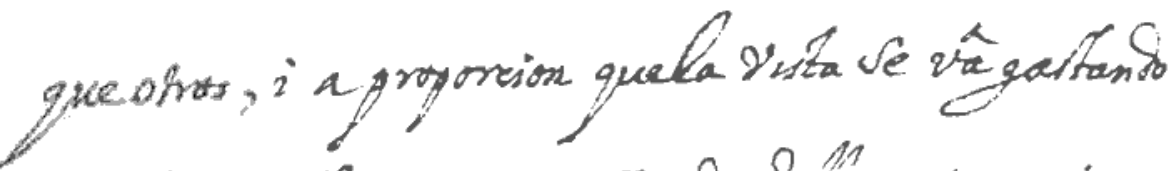

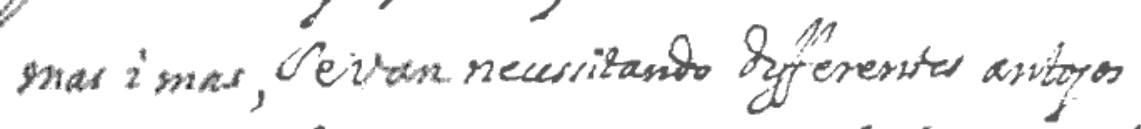
que layan haziento mayor imayor La Céraj i enta 


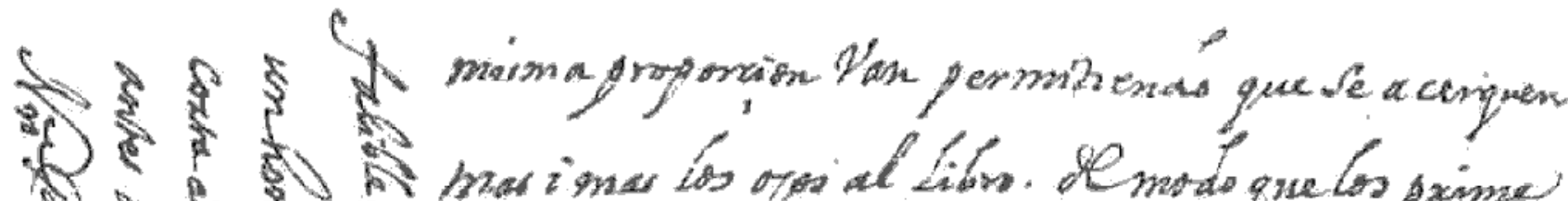

कि है

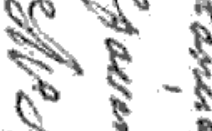

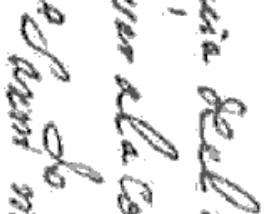

का है की

क. क त

ा1) हो है

क है तो

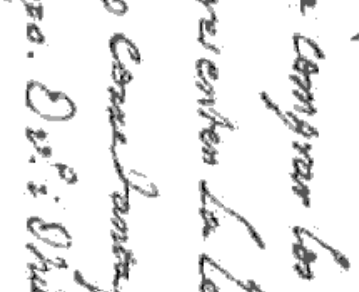

क.

10

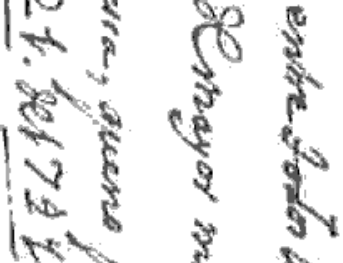

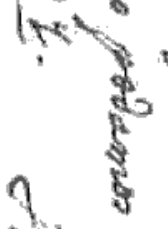

ath

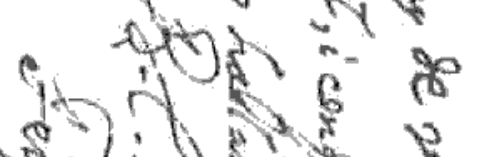

कof

An 8

है

ज्ञ 51

if

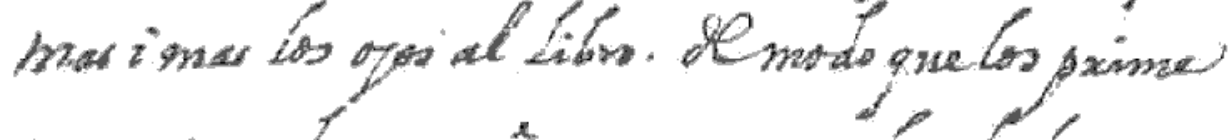

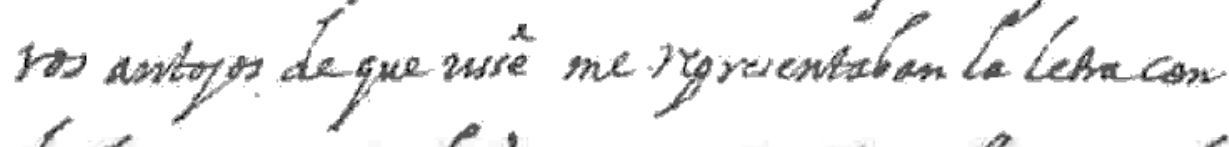

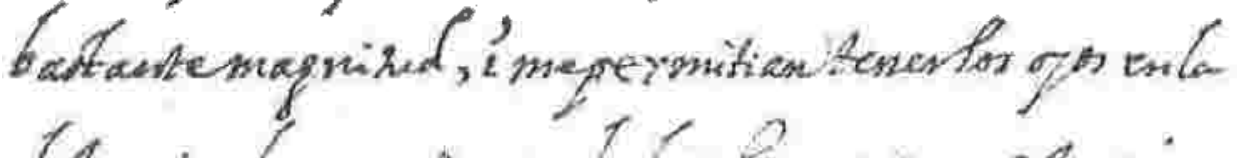

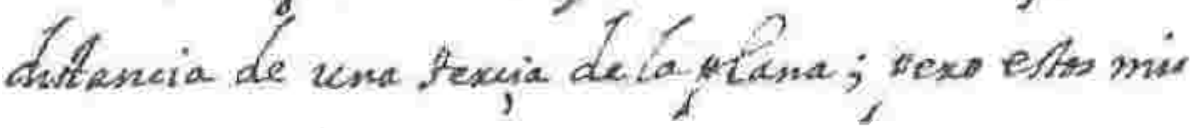

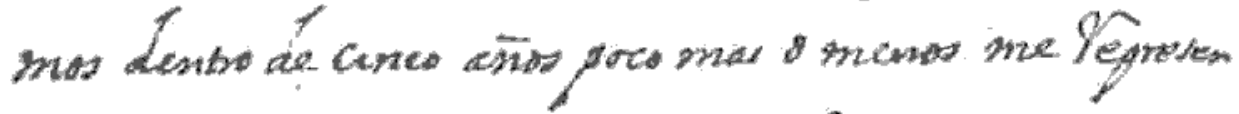

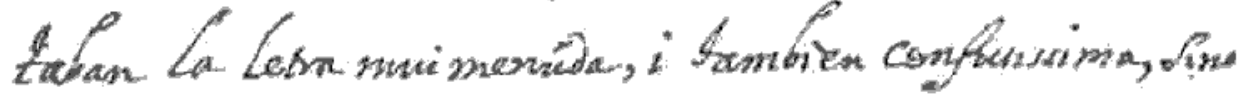

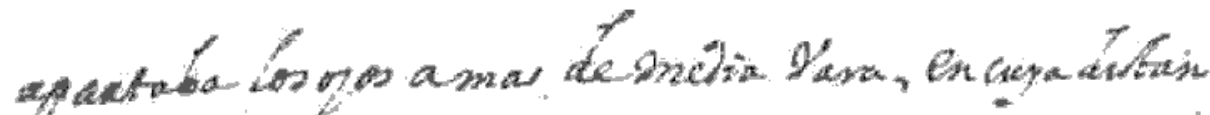

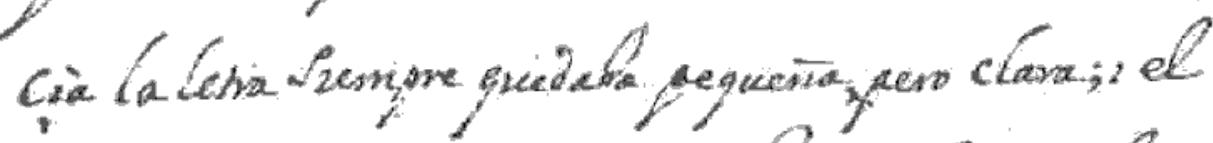
7 , t , s o o

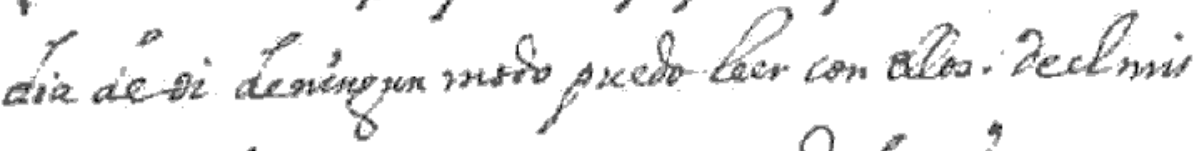

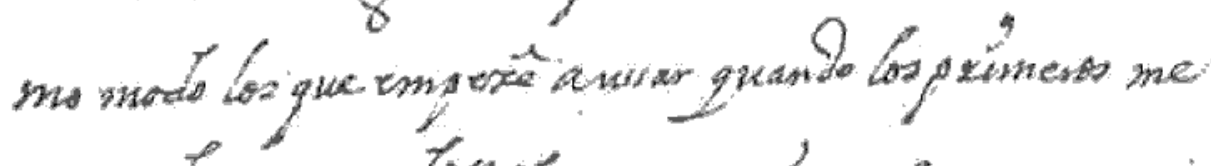

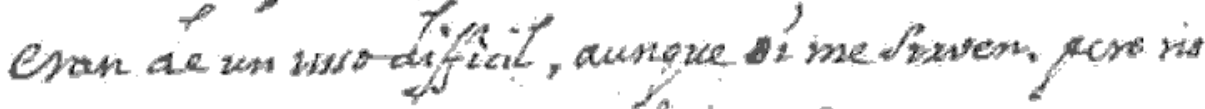

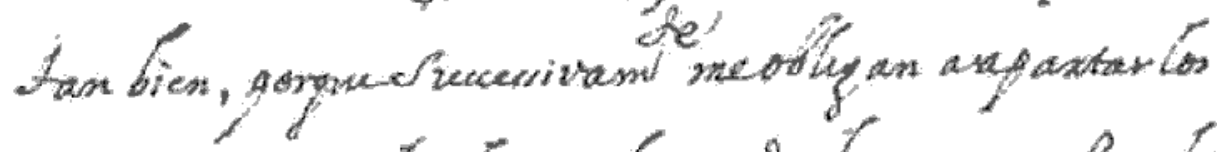

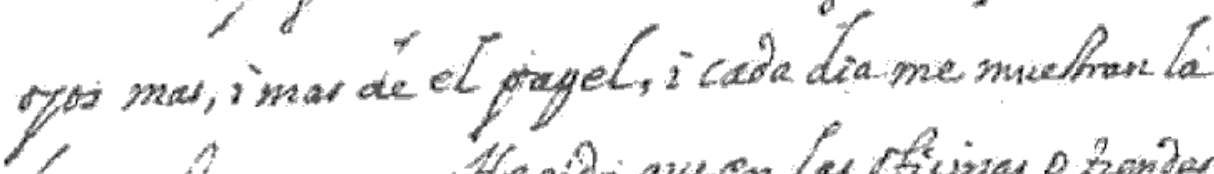

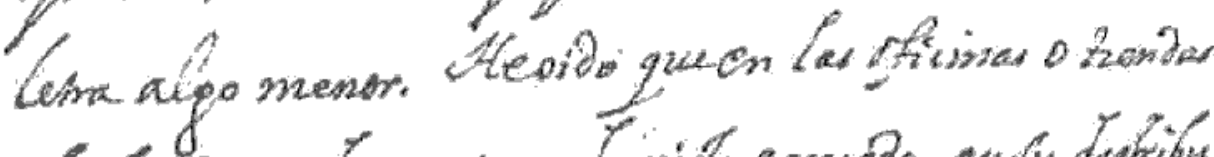

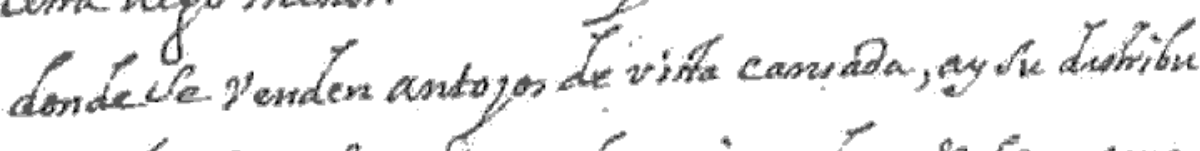

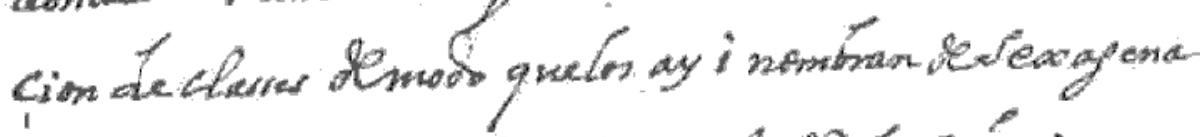

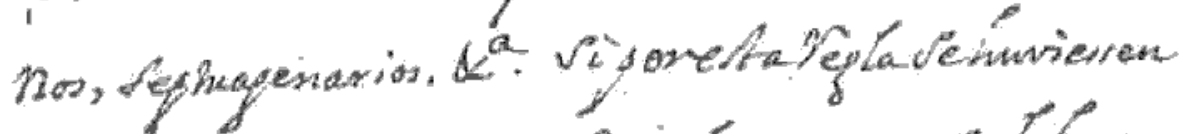
Le comprar gammi encletrato mereste, dedeberian

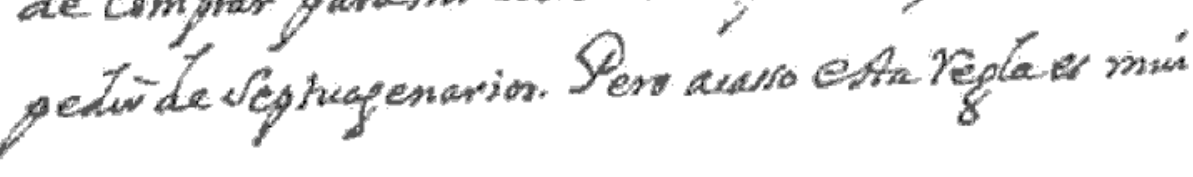


$\infty$

dese

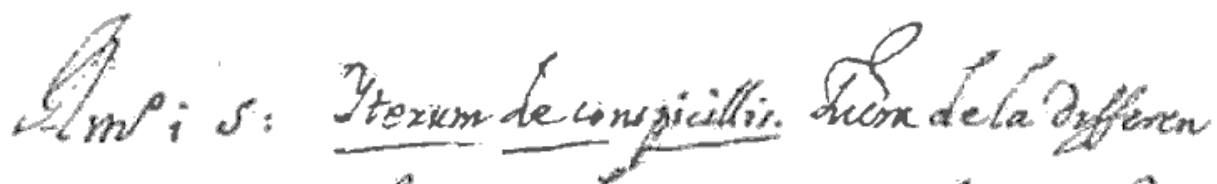

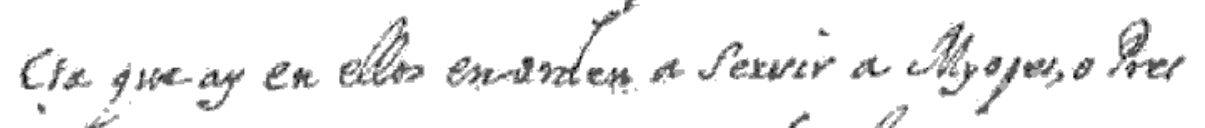

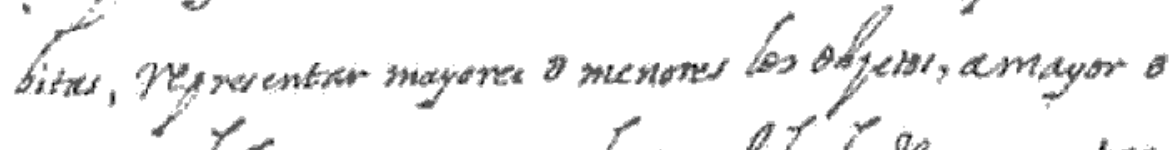

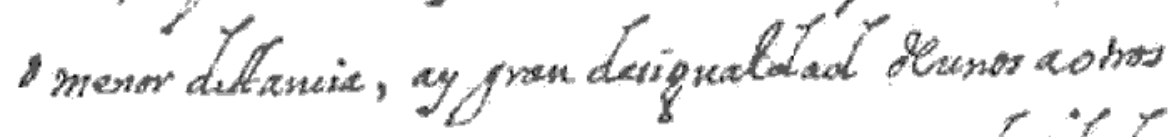
enguanta a Pepxes exsiar con mayor a menor claridad.

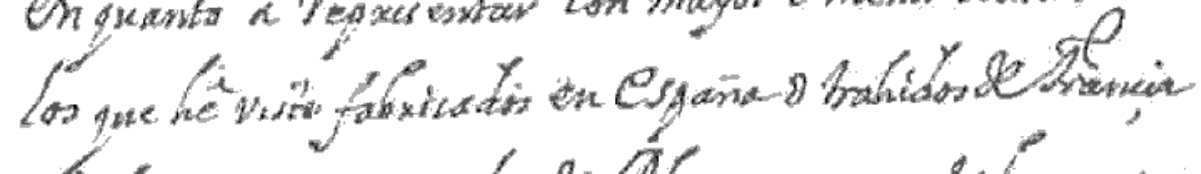

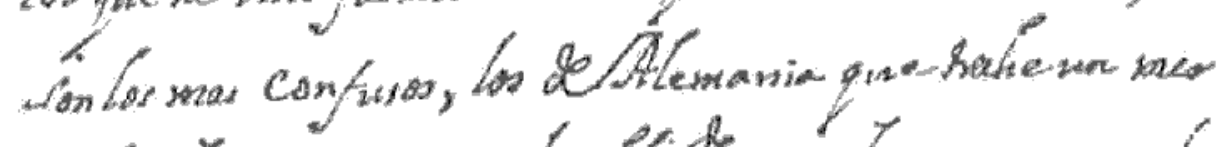

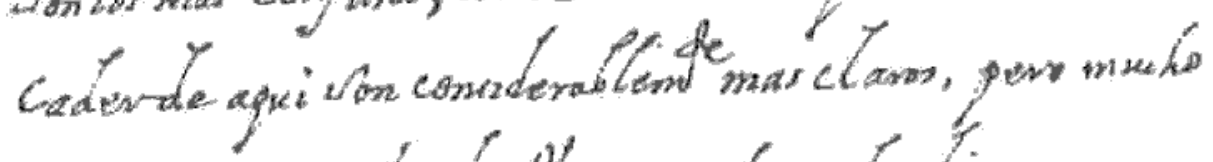

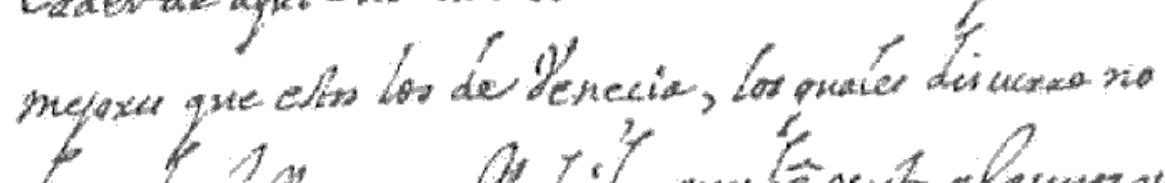

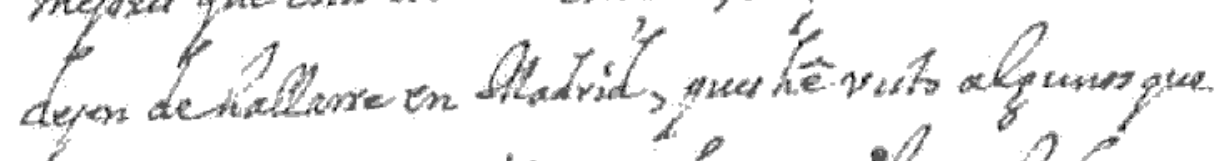

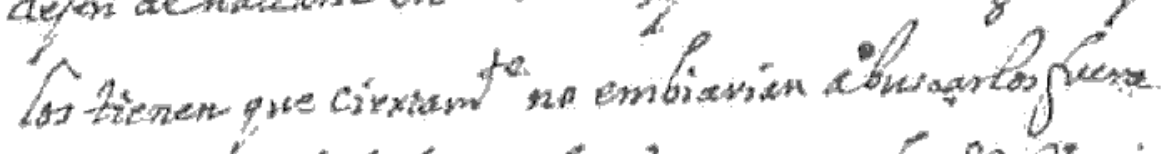

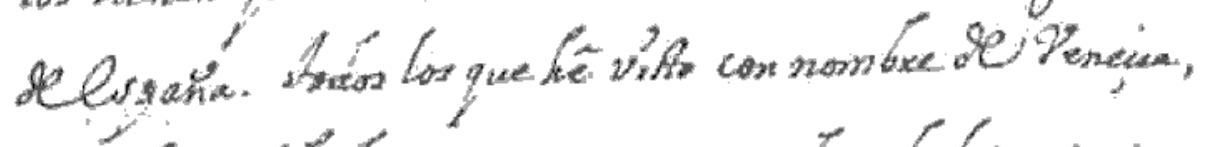

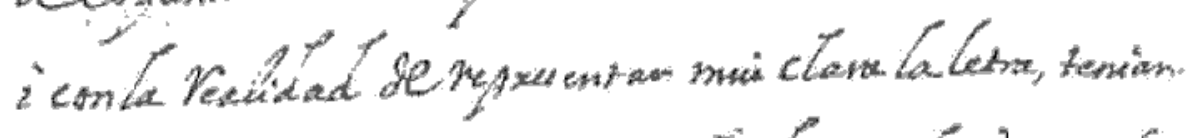

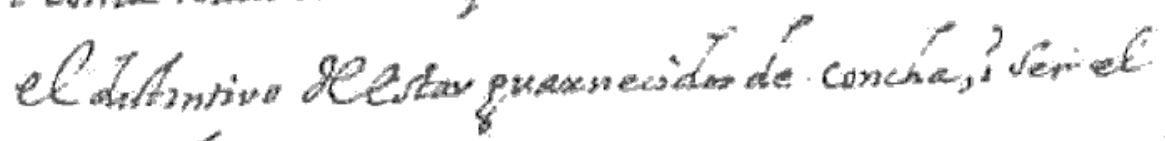
Yidro de sequina circuéterencia.

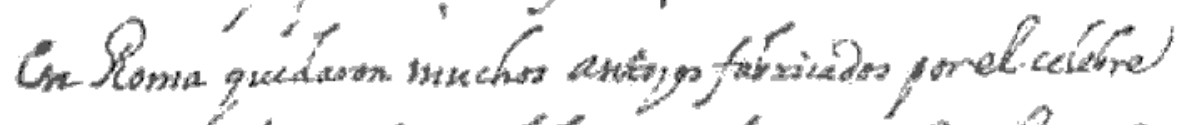

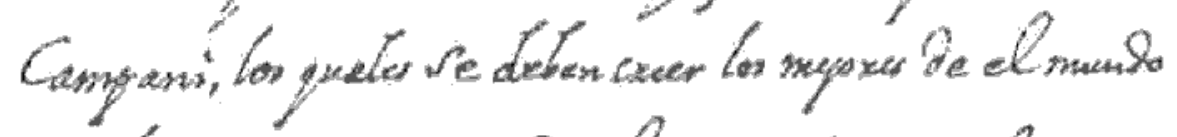

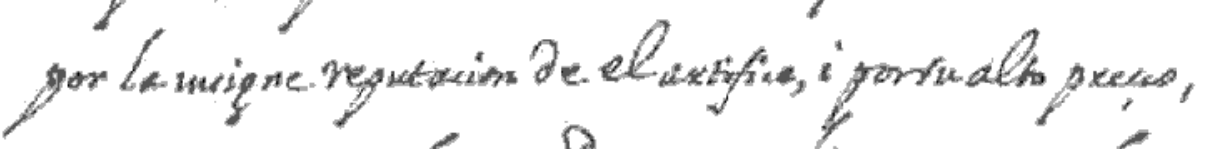

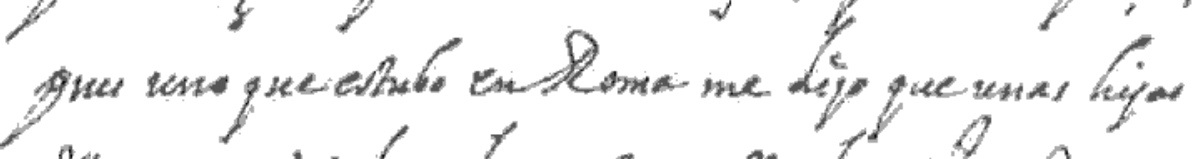

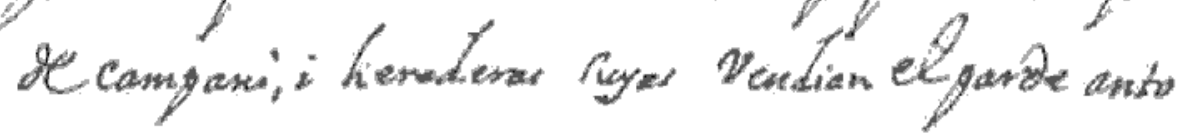




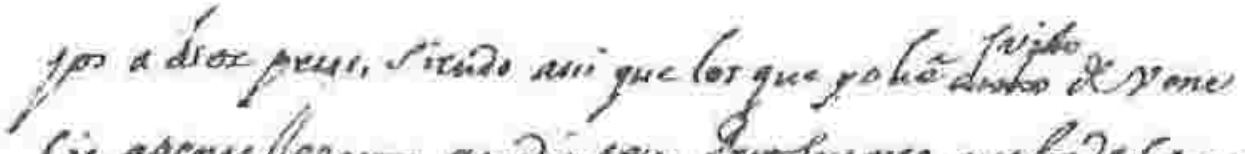

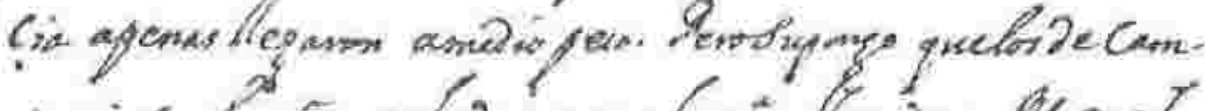

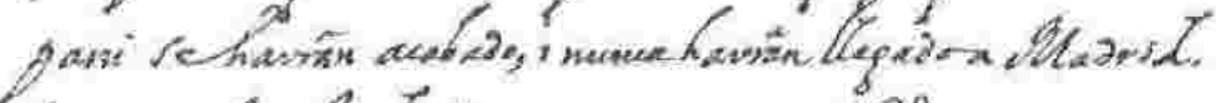

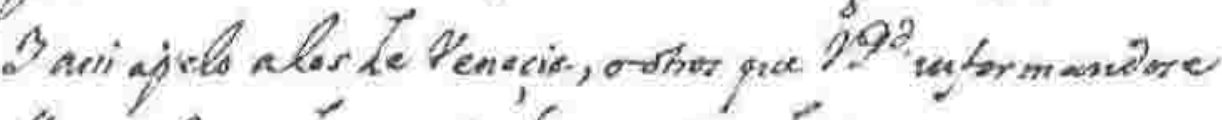

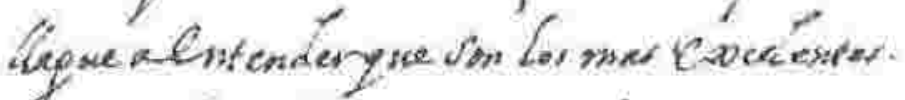

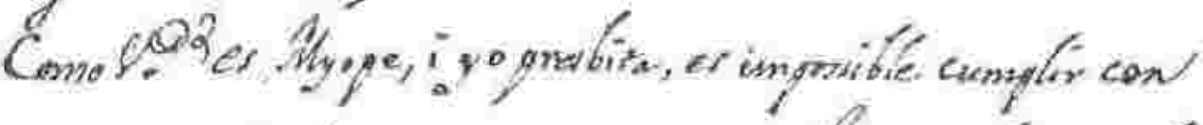

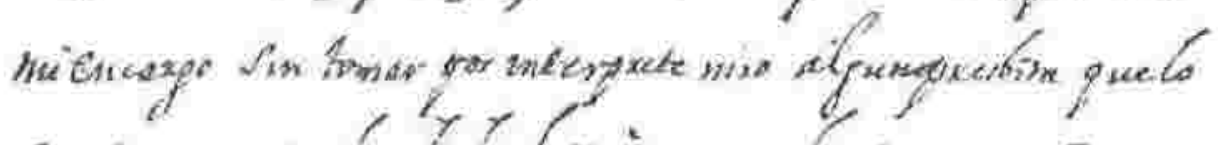

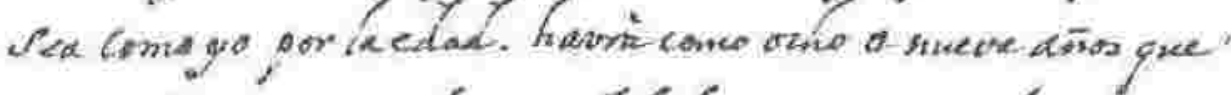

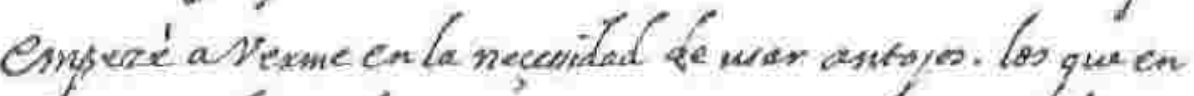
fo bren sino me for the

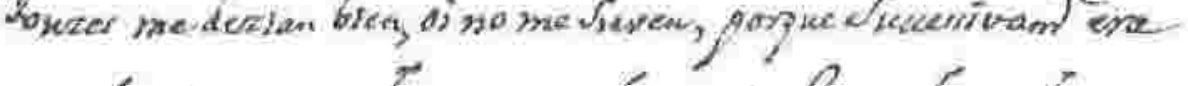

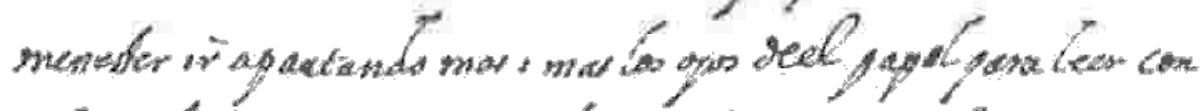

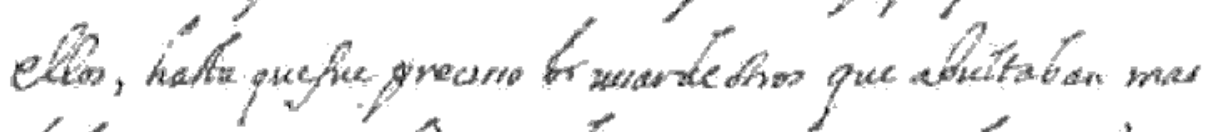

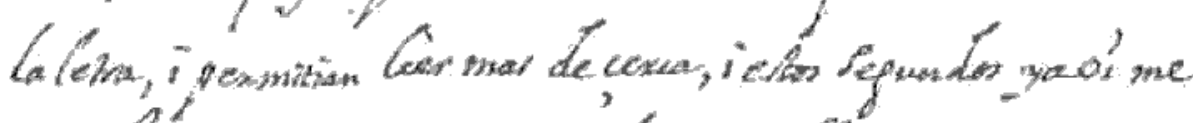

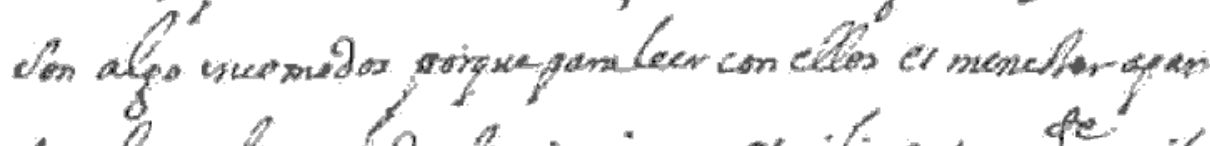

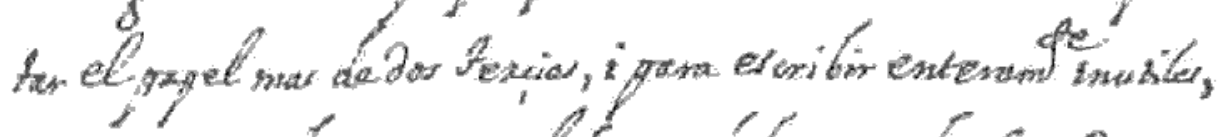

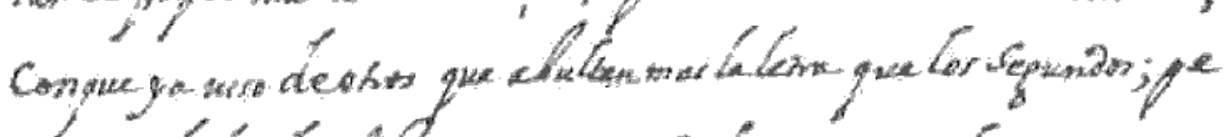

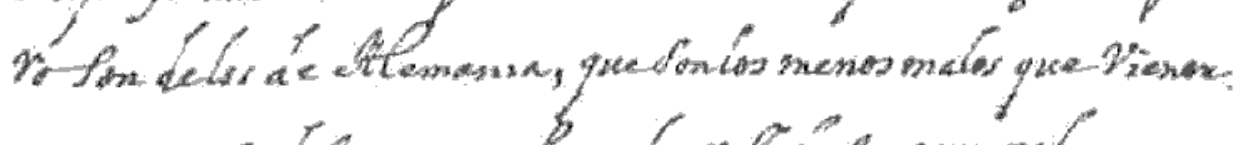

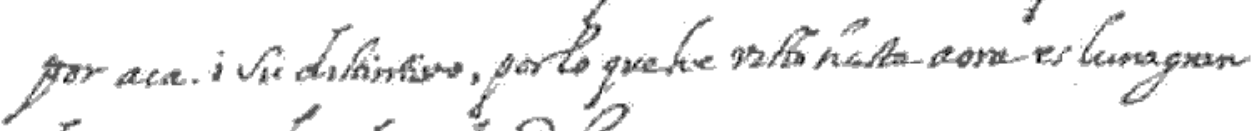

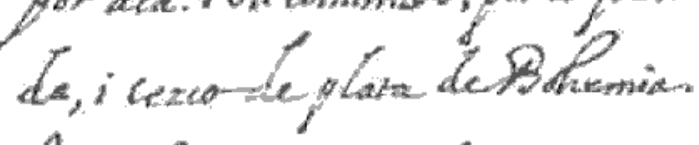

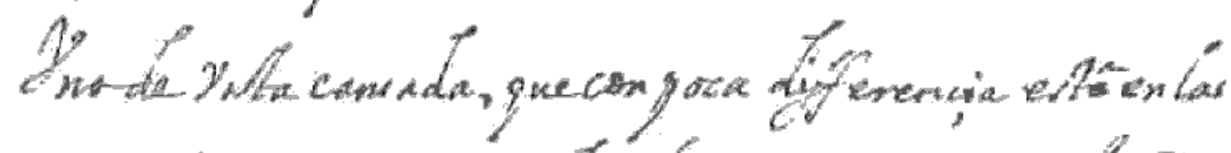

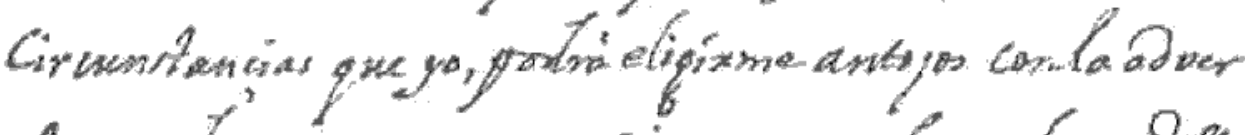

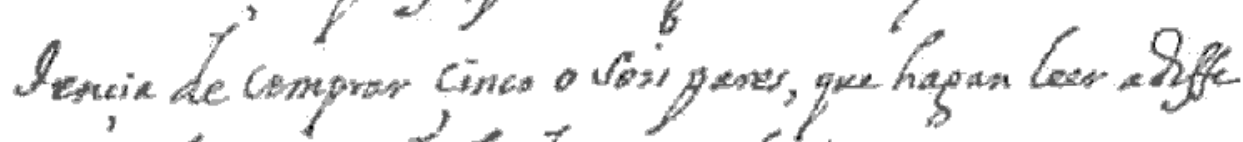

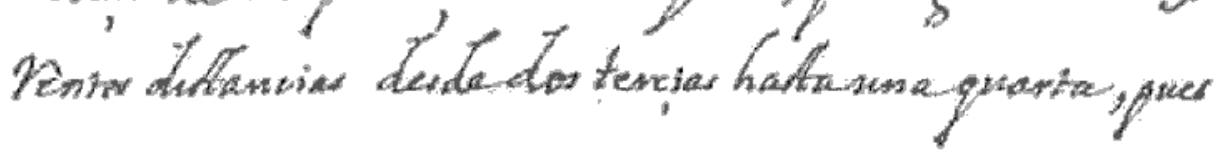


$\infty$

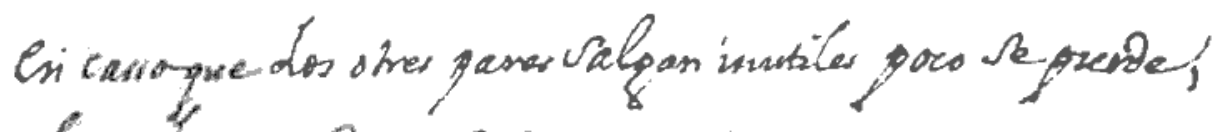
heardequeposman vecion parato iros. Welor que 095 me embio enom ockion, por no haves yo pre

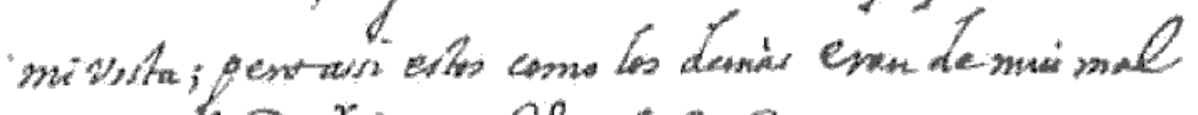

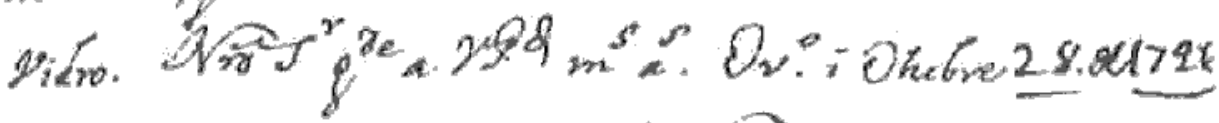

Sien he reido i hize Rir aotroz con la carta sobre el caramiento

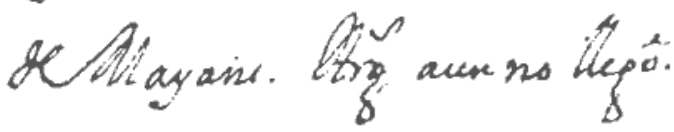

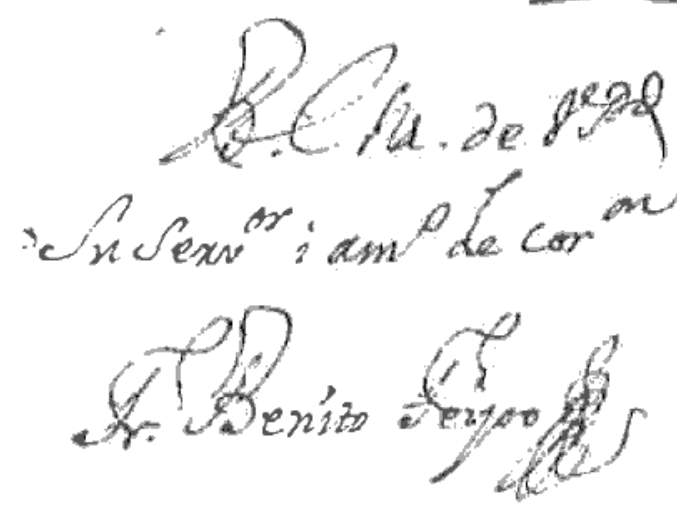

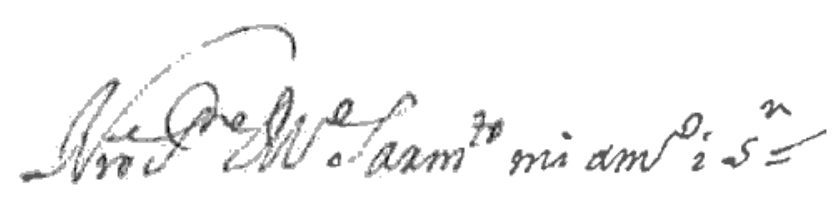


Padre nuestro, amigo i señor: Iterum de conspicillis. Fuera de la differençia que ay en ellos en orden a servir a myopes o présbitas, representar mayores o menores los objetos a mayor o menor distançia, ay gran desigualdad de unos a otros en quanto a representar con mayor o menor claridad. Los que he visto fabricados en España o trahidos de Françia son Ios más confusos; los de Alemania que trahe un mercader de aquí, son considerablemente más claros; pero mucho mejores que éstos los de Venecia, los quales discurro no dejan de hallarse en Madrid, pues he visto algunos que los tienen que ciertamente no embiarían a buscarlos fuera de España. Todos los que he visto con nombre de Veneçia i con la realidad de representar mui clara la letra, tenían el distintivo de estar guarnecidos de concha i ser el vidro de pequeña çircunferençia.

En Roma quedaron muchos antojos fabricados por el célebre Campani ${ }^{52}$, los quales se deben ereer los mejores de el mundo por la insigne reputaçión de el artifice $\mathrm{i}$ por su alto preçio, pues uno que estubo en Roma me dijo que unas hijas de Campani i herederas suyas vendian el par de antojos a diez pesos, siendo assí que los que yo he visto de Veneçia apenas llegaron a medio peso. Pero supongo que los de Campani se havrán acabado i nunca havrán llegado a Madrid. Y assí apelo a los de Veneçia o otros que vuestra paternidad, informándose, llegue a entender que son los más exçelentes.

Como vuestra paternidad es myope i yo présbita, es impossible cumplir con mi encargo sin tomar por intérprete mío algún présbita que lo sea como yo por la edad. Havrá como ocho o nueve años que empezé a verme en la neçessidad de usar antojos. Los que entonces me dezían bien, oi no me sirven, porque successivamente era menester ir apartando más i más los ojos de el papel para leer con ellos, hasta que fue precisso ${ }^{53}$ ussar de otros que abultaban más la letra i permitían leer más de çerca, i estos segundos ya oi me son algo incómodos, porque para leer con ellos es menester apartar el papel más de dos terçias i para escribir enteramente inúti-

52 En el siglo XVII florecieron en Italia dos hermanos, José y Mateo (éste sacerdo. te) Campani, que se distinguieron el primero por su habilidad en confeccionar telescopios y el segundo en la fabricación de aparatos de relojería y de cristales para telescopios. Si bien alude aquí Feijoo a «unas hijas de Campani i herederas suyas», quizá pudiéramos pensar que se trata de Mateo, cuyos bienes, como sobrinas suyas, habrían heredado las hijas de José Campani.

53 En el original entre precisso y ussar aparece una o precedida de un rasgo vertical que parece una $l$ y seguida de una especie de coma $(=$,$) , que no encajan con el$ sentido de la cláusula. Posiblemente Feijoo pensaria dar a la frase un sentido disyuntivo, que luego, al correr de la pluma, no realizó. 
les, conque ya usso de otros que abultan más la letra que los segundos; pero son de los de Alemania, que son los menos malos que vienen por acá, i su distintivo, por lo que he visto hasta aora, es luna grande i cerca de plata de Bohemia.

Uno de vista cansada que con poca differençia esté en las circunstançias que yo, podrá elegirme antojos, con la advertençia de comprar çinco o seis pares, que hagan leer a differentes distancias desde dos terçias hasta una quarta, pues, en casso que dos o tres pares salgan inútiles, poco se pierde, fuera de que podrán servir para otros.

De los que vuestra paternidad me embió en otra ocasión, por no haver yo prevenido las notiçias que aora, sólo unos eran proporcionados a mi vista; pero assí éstos como los demás eran de mui mal vidro.

Nuestro Señor guarde a vuestra paternidad muchos años.

Oviedo i otubre 28 de 1741.

Besa la mano de vuestra paternidad su servidor i amigo de corazón,

$$
\text { Fr. Benito Feijoo [rubricado] }
$$

Nuestro padre maestro Sarmiento, mi amigo i señor.

[Nota marginal:] Bien he reído i hize reir a otros con la carta sobre el casamiento de Mayans ${ }^{54}$. Argüelles aún no llegó.

1742, enero, 6. Oviedo

COMPARA SUS “PRENDAS DE ESCRITOR» CON LAS DE SU CORRESPONSAL Y AMIGO. - LA Naturalidad, “PRenda inexcusable en la poesía»: Alabanza y crítica de góngora.

AMS, carp. C 1, núm. 10. Original autógrafa.

Pub., en parte: G. Marax̃ón, o. c., 108, nota 3.

Cita: G. Delpy, o. c., 208-209 y 369, 1 a $^{\text {col. }}$

54 Gregorio Mayáns y Siscar, gramático y jurista valenciano (1699-1781). Feijoo en el discurso $\mathrm{X}, \mathrm{n}{ }^{\circ} \mathrm{100}$, del tomo VII del Theatro lo alaba llamándolo "sabio y laborioso" al referirse a las “cartas de varios discretos españoles» publicadas por el escritor valenciano. Sin embargo, la aparición, en 1728, de la Ortografía castellana de Antonia Bordazar de Artazu, la cual Feijoo pensó por algún tiempo ser obra del propio Mayán y Sis- 


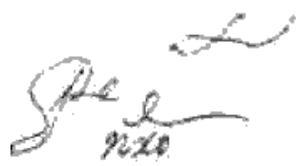

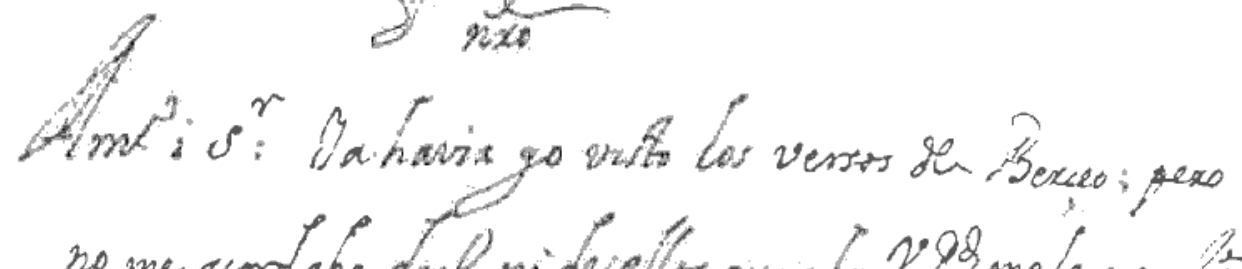

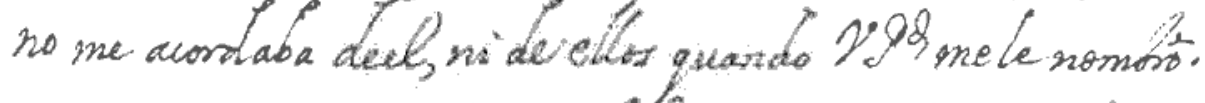

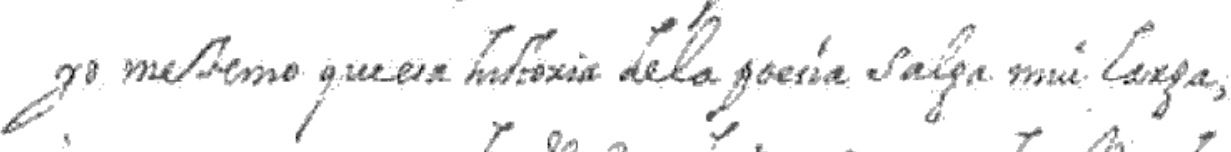

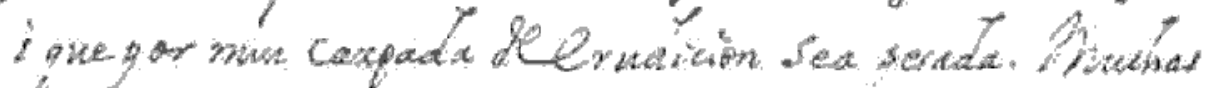

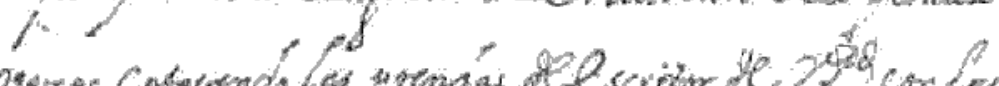

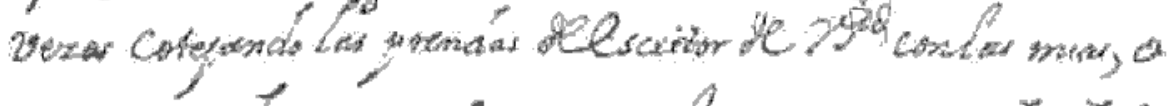

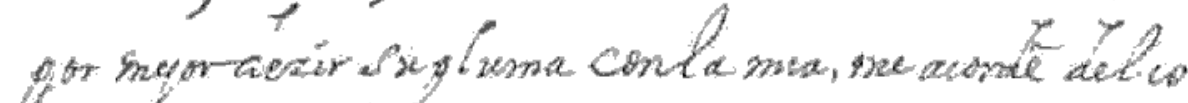

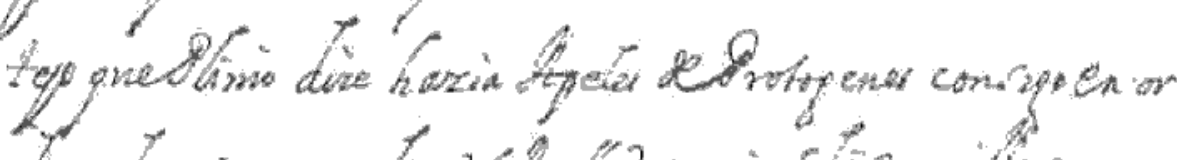

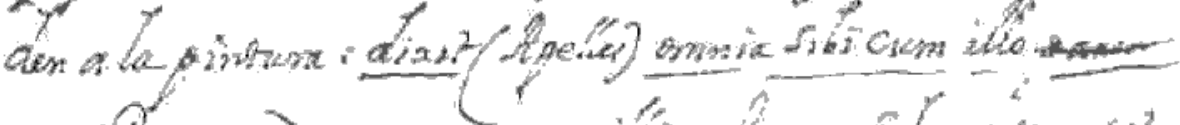

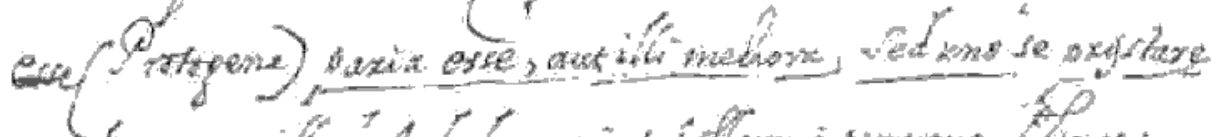

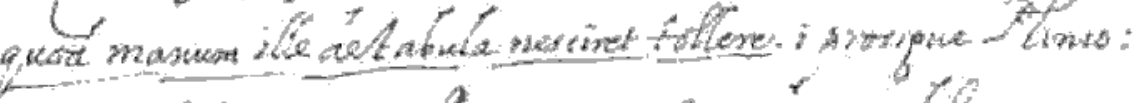

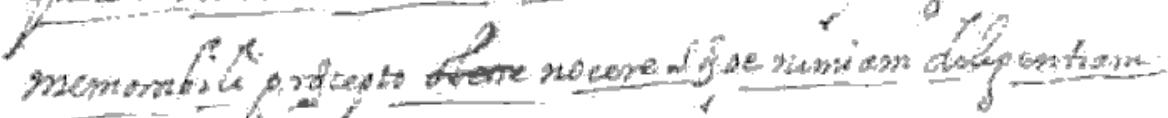

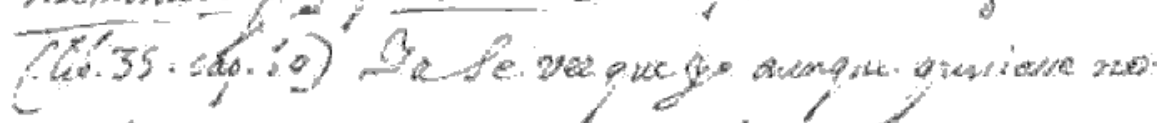

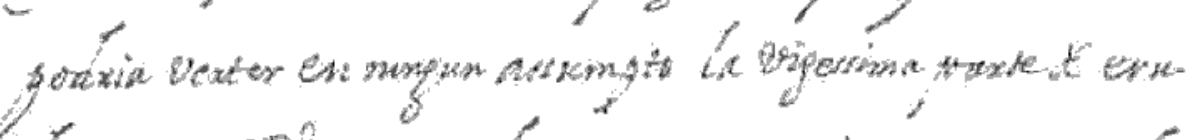

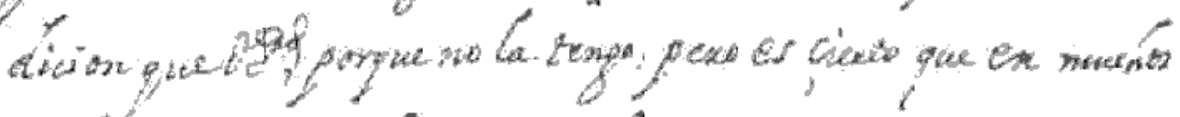
7.

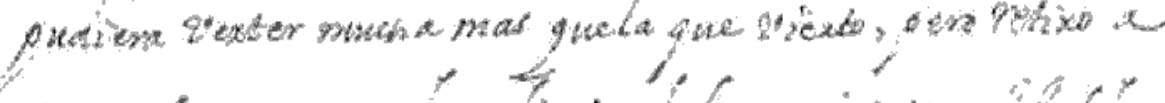

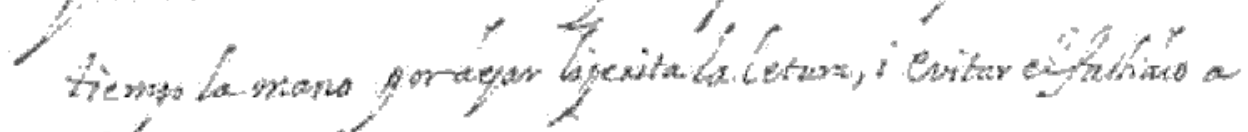

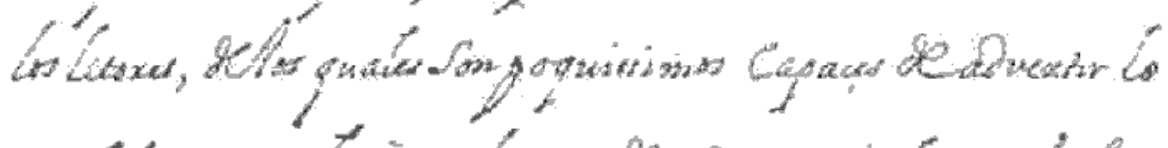

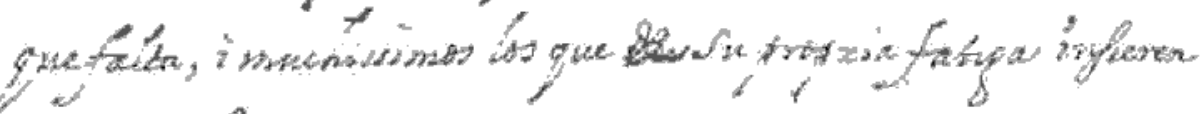

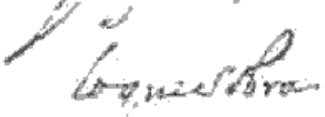

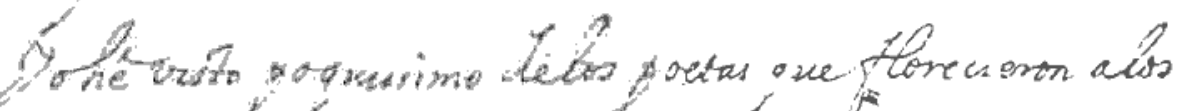

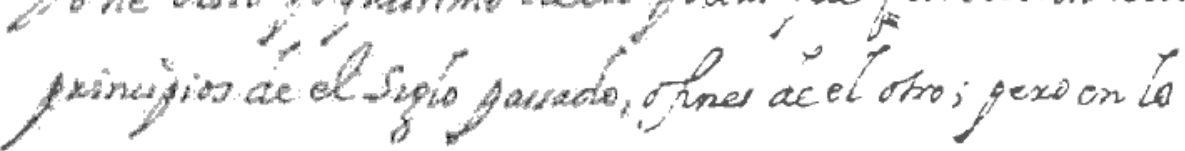


$\alpha$

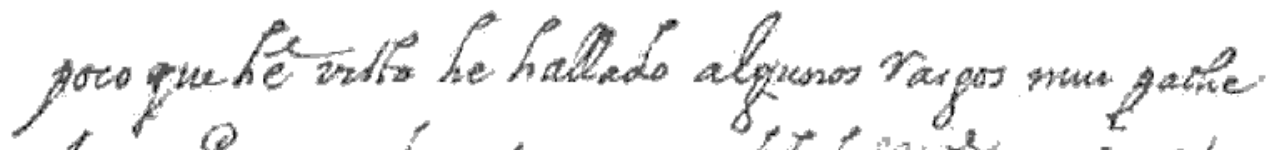

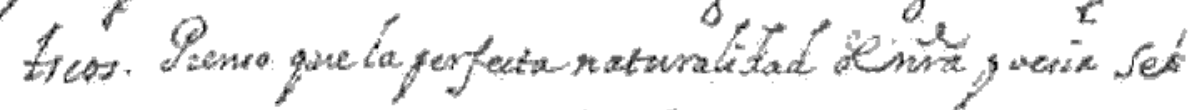

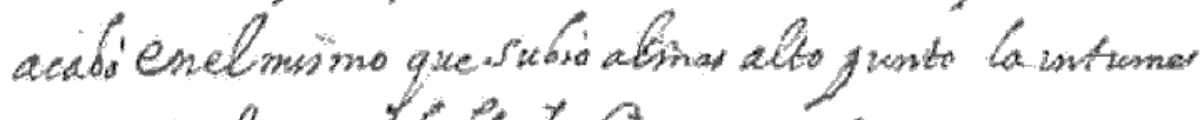

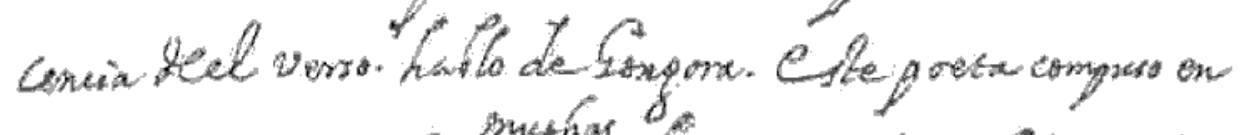

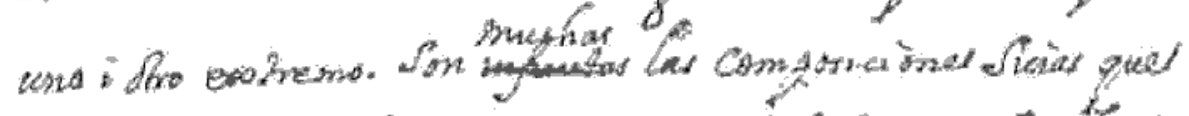

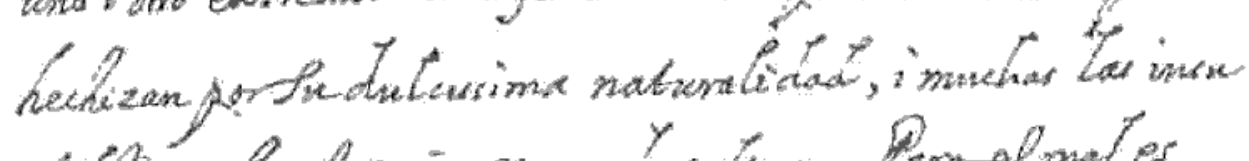

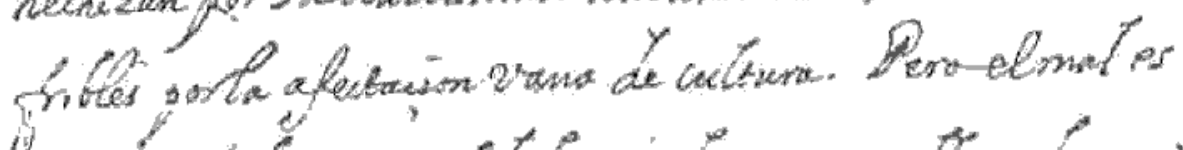

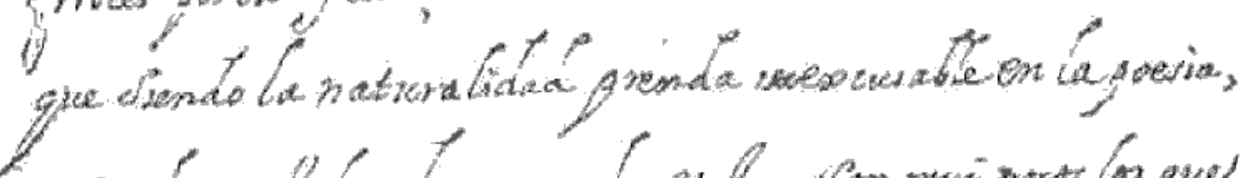
2 Sin La qual Las demas nada valem, om man pors los que

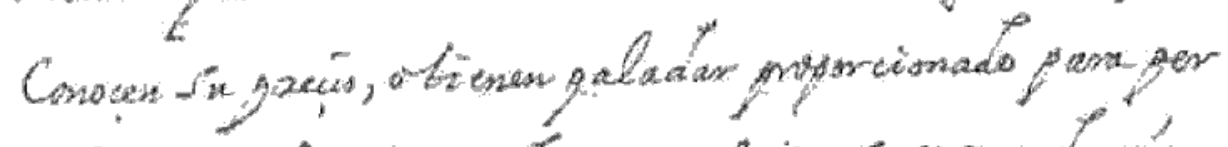

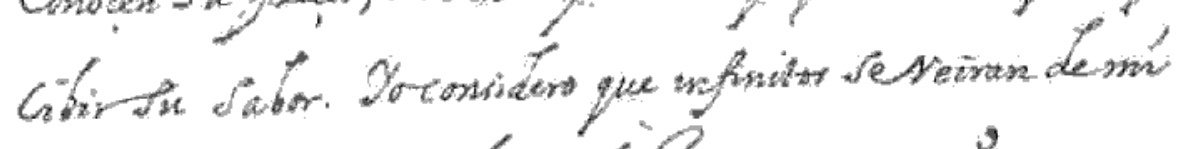

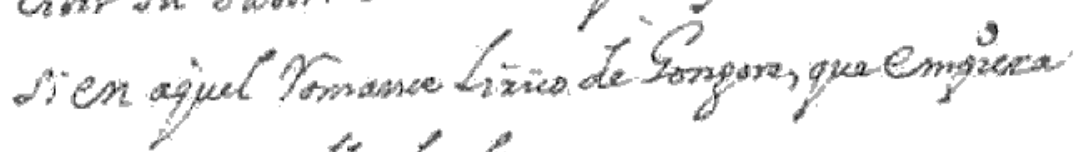

Corabalana

(Finia: Laron)

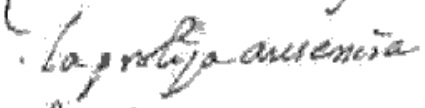

Le suinorato amor.

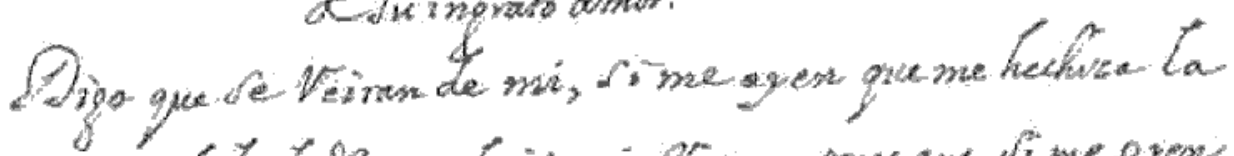

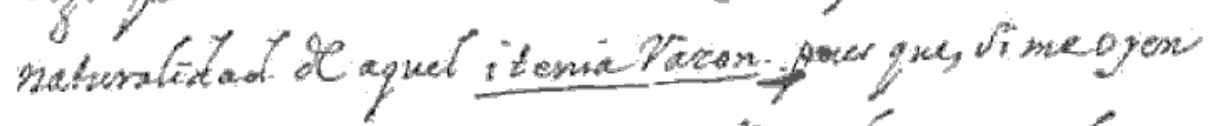

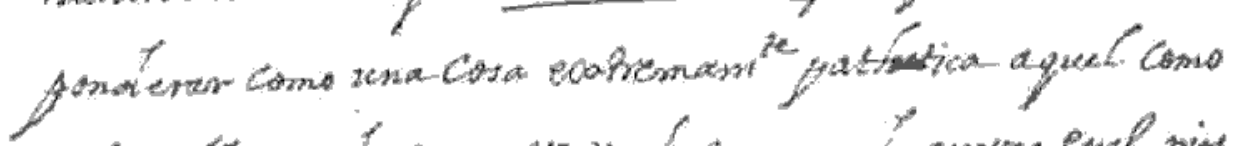

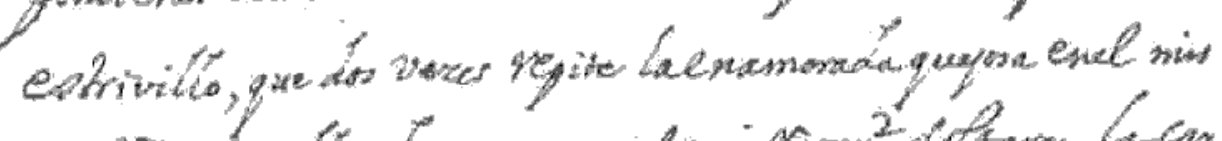

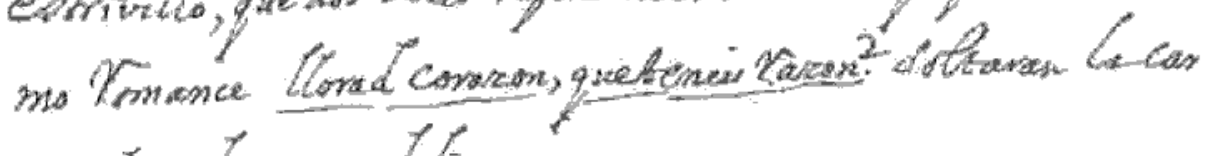

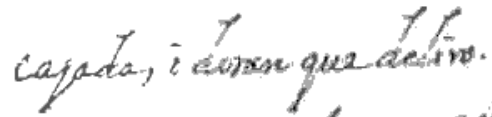

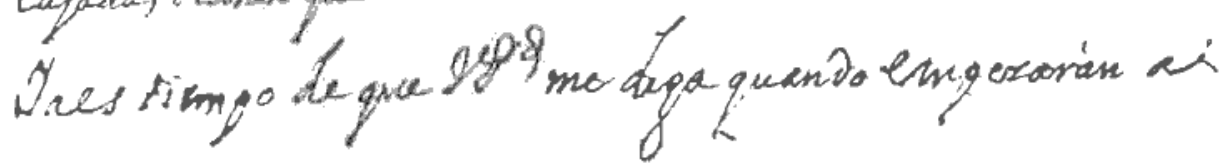


$\infty$

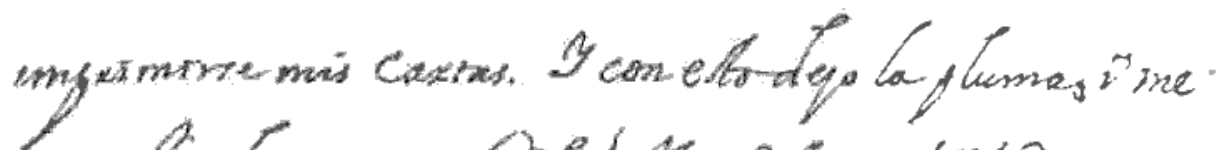

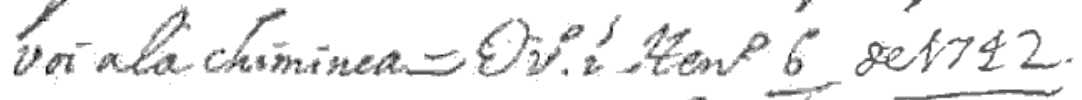

Pe

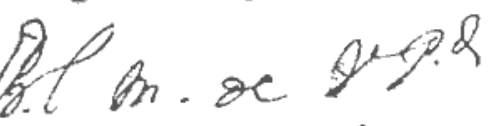

Sulexy, am de cor on

cobenito seipos

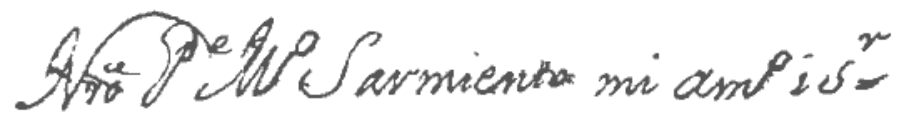


Padre nuestro, amigo i señor: Ya havía yo visto los versos de Berçeo, pero no me acordaba de él ni de ellos quando vuestra paternidad me lo nombró. Yo me temo que esa historia de la poesía salga mui larga i que, por mui cargada de erudición, sea pesada. Muchas vezes cotejando las prendas de escritor de vuestra paternidad con las mías o, por mejor dezir, su pluma con la mía, me acordé del cotejo que Plinio dize hazía Apeles de Protogenes consigo en orden a la pintura: Dixit (Apelles) omnia sibi cum illo (Protogene) paria esse, aut illi meliora, sed uno se praestare quod manum ille de tabula nesciret tollere; i prosigue Plinio: memorabili praecepto nocere saepe nimiam diligentiam (libro 35 , capítulo 10 ). Ya se vee que yo, aunque quisiesse, no podría verter en ningún assumpto la vigéssima parte de erudición que vuestra paternidad, porque no la tengo, pero es çierto que en muchos pudiera verter mucha más que la que vierto; pero retiro a tiempo Ia mano por dejar lijerita la letura i evitar el fastidio a los letores, de los quales son poquíssimos capaçes de advertir lo que falta i muchíssimos los que de su propria fatiga infieren lo que sobra.

Yo he visto poquíssimo de los poetas que florecieron a los principios de el siglo passado o fines de el otro; pero en lo poco que he visto, he hallado algunos rasgos mui pathéticos. Pienso que la perfecta naturalidad de nuestra poesía se acabó en el mismo que subió al más alto punto la intumesçencia de el verso. Hablo de Góngora. Este poeta compuso en uno i otro extremo. Son muchas las composiciones suias que hechizan por su dulcíssima naturalidad $\mathrm{i}$ muchas las insufribles por la afectaçión vana de cultura. Pero el mal es que, siendo la naturalidad prenda inexcusable en la poessía i sin la qual las demás nada valen, son mui pocos los que conoçen su preçio o tienen paladar proporcionado para percibir su sabor. Yo considero que infinitos se reirán de mí si en aquel romançe lírico de Góngora que empieza:

ear - aunque después confesó su error al misma Mayáns en carta del 13 de octubre de 1731- fue causa de que se cufriasen las relaciones amistosas entre ambos eruditos. Una muestra de ello es el tono irónico con que se exprea aquí el P. Matstro. Pueden verse más detalles sobre el asunto en J. A. TAmayo, Maycins y la "Ortografía) de Bordázar:

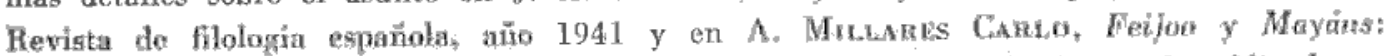
Revista de filologin española, año 1923. La carta do Feijoo a Mayáns egtá publicada en «Bibliotees de autores españoless, t. 62, p. 154. De esta como de otras fricoiones entre Feijoo y Mayáns, ajorta nuevos datos Antomio Mestre, Divergencrios entre ilustrados: El caso Feijoo-Mayáns: Studium Ovetense 4 (1976) 275-304. 


\section{Lloraba la niña \\ (i tenía razón) \\ la prolija ausençia \\ de su ingrato amor;}

digo que se reirán de mí si me oyen que me hechiza la naturalidad de aquel i tenía razón. Pues ¿qué si me oyen ponderar como una cosa extremamente pathética aquel como estrivillo que dos vezes repite la enamorada quejosa en el mismo romançe: llorad, corazón, que tenéis razón? Soltarán la carcajada i dirán que deliro.

Ya es tiempo de que vuestra paternidad me diga quándo empezarán a imprimirse mis Cartas ${ }^{55}$. Y con esto dejo la pluma i me voi a la chiminea.

Oviedo i henero 6 de 1742.

Padre nuestro, besa la mano de vuestra paternidad su servidor $\mathrm{i}$ amigo de corazón,

\section{Fr. Benito Feijoo [rubricado]}

Nuestro padre maestro Sarmiento, mi amigo i señor.

1744, febrero, 1. Oviedo

alude a los datos que su corresponsal le había enviado acerca de los brin. Dis. --Alaba Y CRItica Un retrato suyo realizado por el pintor bustamante.

AMS, carp. C 1, núm. 11. Copia.

Pub., en parte: G. Marañón, o. c., 143 y 290.

Cita: G. Delpy, o. c., 30, 281 y $385,1 .^{a}$ y $2,^{a}$ col.

Padre nuestro, amigo i señor: Vino la erudición griega, latina, hebrea, alemana, sobre los brindis, de que me aprovechare lo menos mal que pueda. Lástima es que no haya algo de lengua eselavona al caso, porque tengo a esta lengua mucha afición, sin saber qué cosa es, como don Quijote a su incógnita Dulcinea.

53 Después de haber concluido la impresión de los tomos del Theatro en 1741, en Ios albores del siguiente año tenía ya listo el primero de las Cartas, según se desprende de este párrafo. Este primer tomo se publicó en setiembre de '1742. 
Sobre el retrato, cuyo diseño vino también, lo que me parece es que al hábito se dé representación de ser de anascote, en que faltó enormemente Bustamante ${ }^{56}$ representando una estameña bastíssima, de la que vestían un tiempo los capuchinos. Tampoco tiene la forma de saya ni de ropón, y en alguno de los dos hábitos me vio cuando me pintó. El rostro está bien sacado por la lámina. Sólo quisiera que, siendo posible, se diese algo de viveza y agrado a los ojos: digo «siendo posible», porque no sé si lo es en mero dibujo sin colores. Bustamante ni con ellos acertó jamás a figurar afecto alguno en el rostro, habiendo copiado infinitos; i assí en todas sus copias, aún las que saca por otras pinturas de mucha alma en el semblante, deja unos ojos neutros o indiferentes.

Anteayer tarde, si no mintió a mediodía, salió Argüelles para Madrid. Entregué al colegial Soto los sesenta reales; i haré todo lo demás que el hidalguísimo Vallejo ${ }^{57}$ me mandare. Supongo que el Tratado de la restauración de la literatura se quedará siempre en manuscrito y sin efecto.

Alégrome del nuevo invento para hacer más útiles las minas, que nunca más oportuno que cuando se buscan con tanta ansia la plata y el oro.

Nuestro Señor guarde a vuestra paternidad muchos años.

Oviedo i febrero 1 de 1744 .

Padre nuestro, besa la mano de vuestra paternidad su servidor i amigo de corazón,

\section{Fr. Benito Feijoo}

Nuestro padre maestro Sarmiento, mi amigo i señor.

1748, junio, 5. Oviedo

SOBRE ASUNTOS PARTICULARES DE ALgunos DE SUS HERMANOS DE HÁbITO. -ALABA EL BUEN COMPORTAMIENTO DEL PADRE GENERAL CON LA COMUNIDAD DE SAMOS.

56 Francisco Bustamante, pintor asturiano, nacido en Oviedo hacia 1680 y muerto en Gijón en 1737, según Ceán Bermúdez; en 1743, según Jovellanos. Son obra suya los frescos de la sacristía de la catedral ovetense.

57 Véase el Apéndice final. 
AMS, carp. C 1, núm. 12. Copia.

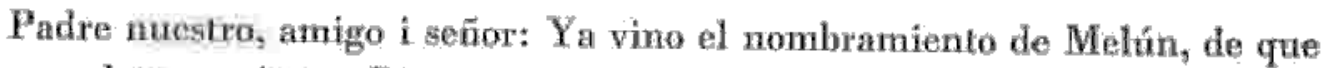
doy muchas gracias a Dios y luego se las daré también a nuestro padre general ${ }^{5}$, a quien la casa de Samos debe levantar estatua, porque en el espacio de dos años le dio dos plazas tescolásticas i tres oratorias. Deseo saber en qué estado tiene el maestro Diez ${ }^{59}$ su recurso al nuncio i si su intento se extiende a que se declane nula la elección hecha, o sólo a precaver otras semejantes para en adelante.

Nuestro Señor guarde a vuestra paternidad muchos años.

Oviedo i junio 5 de 1748.

Padre nuestro, besa la mano de vuestra paternidad,

$$
\text { Fr. Benito Feijoo }
$$

Nuestro padre maestro Sarmiento, mi amigo i señor.

[Nota marginal:] ¿Qué se hace Dios de Vallejo? ${ }^{60}$.

1748, julio, 24. Oviedo

SE DUele de la muerte del P. Vallejo, Que atendía las ganancias de venta de SUS libros. - EPIDEMIA dE VIRUELAS $Y$ DE TIFUS EN ASTURIas.

AMS, carp. C 1, núm. 13. Original outógrafa.

Pub.: G. Marañón, o. c., 138-39, nota 1.

Padre nuestro, amigo i señor: La muerte de el amigo Vallejo ${ }^{61}$ me es mui sensible, porque çierto le amaba yo tiernamente por su mucha bondad i honrradez.

58 P. Plácido Cortada, general de la congregeión los años 1745 al 1749. Monje profeso de Montserrat, del que fue abad desde 1737 hasta 1741. Concluido el generalato, fue elegido abad de San Martín de Madrid (1749-53). Murió en 1756.

59 P. Jacinto Díez. Fue definidor en los cuatrienios 1729-33 y 1737-41.

60 Véase el Apéndice final.

61 Véase el Apéndice final. 
be

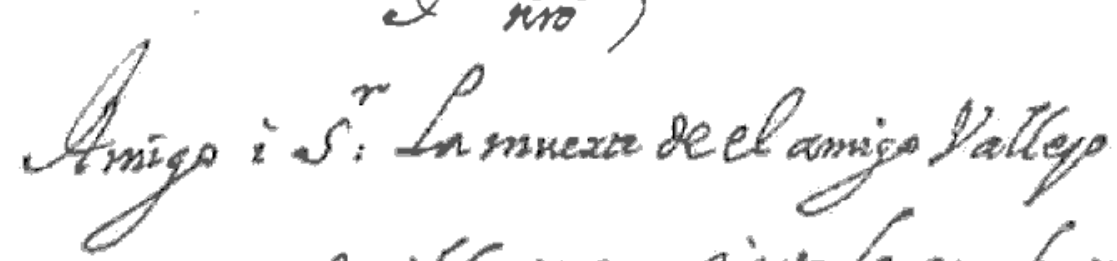
me er mi Serrible, gorgue cixto Leamabayo

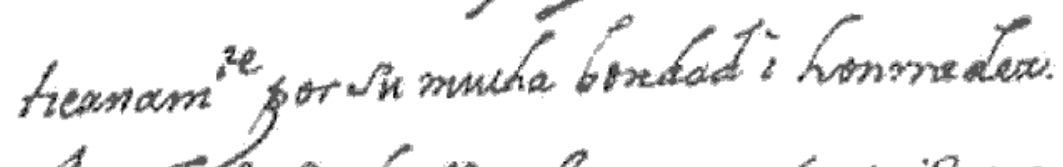

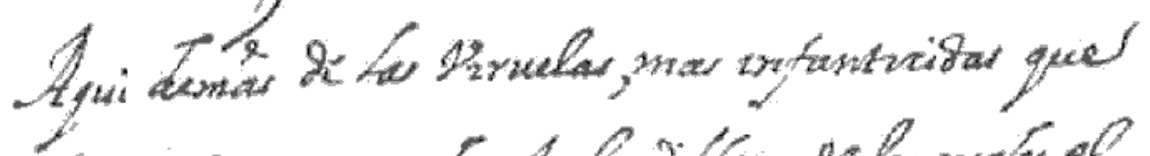
Heroter, ay mushor dabiantions, oclos guater el

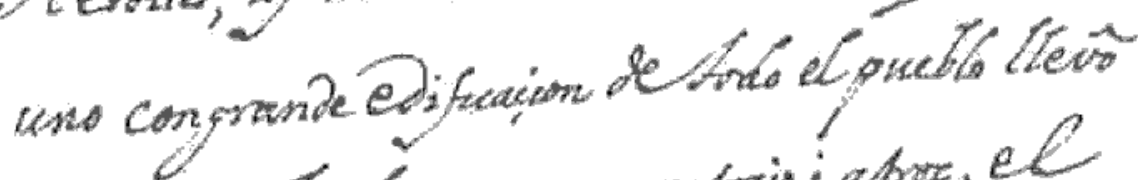

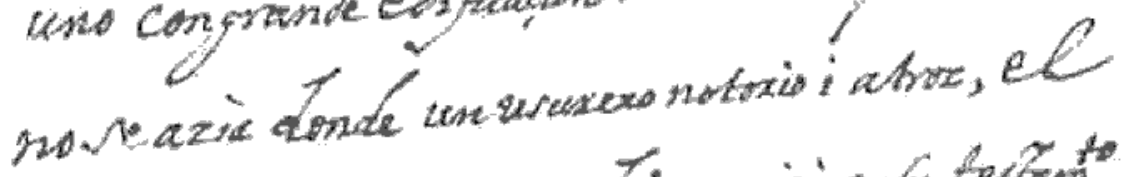

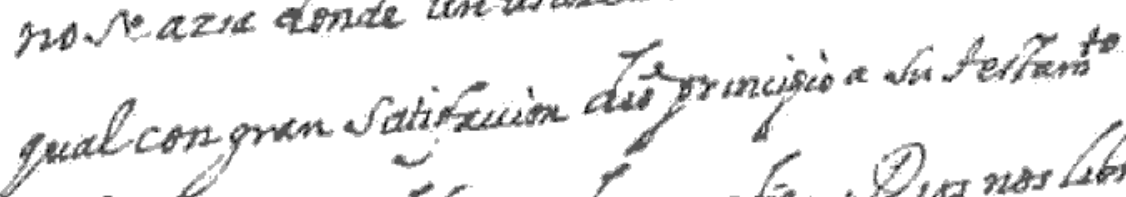

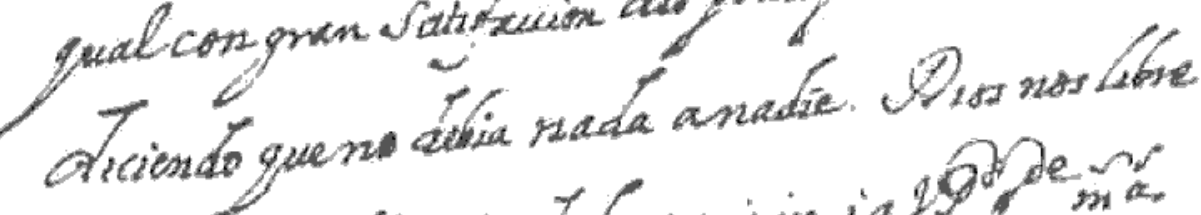

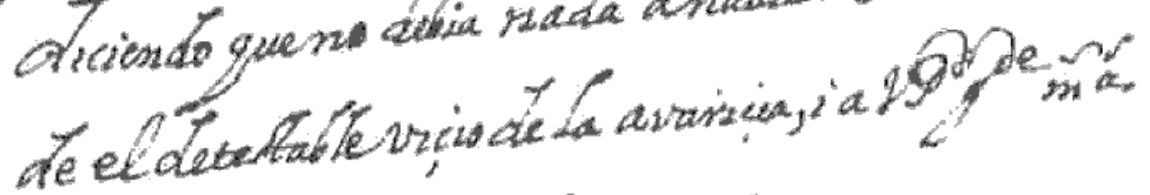

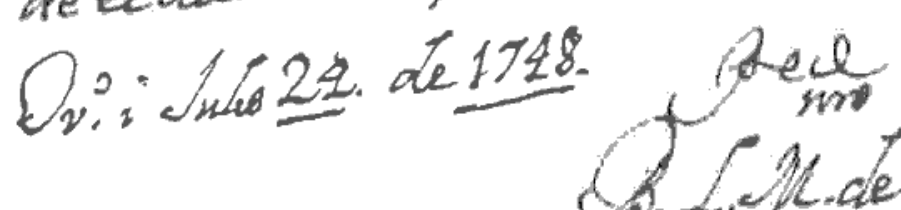

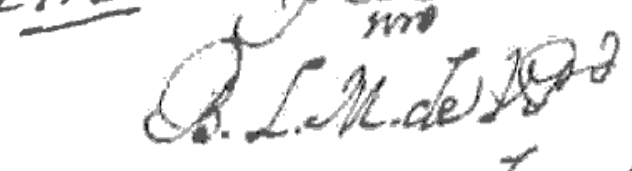

$$
\text { Crusevians de cor }
$$

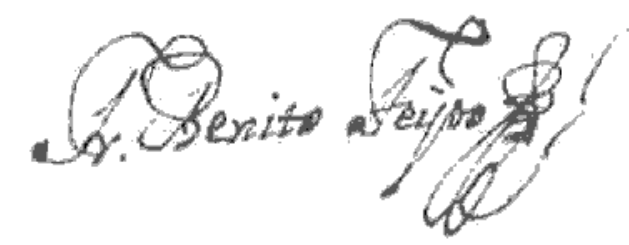

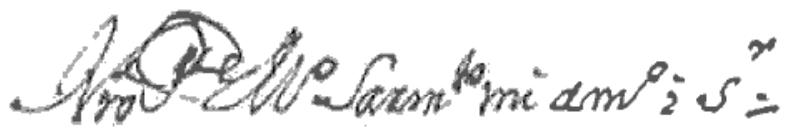



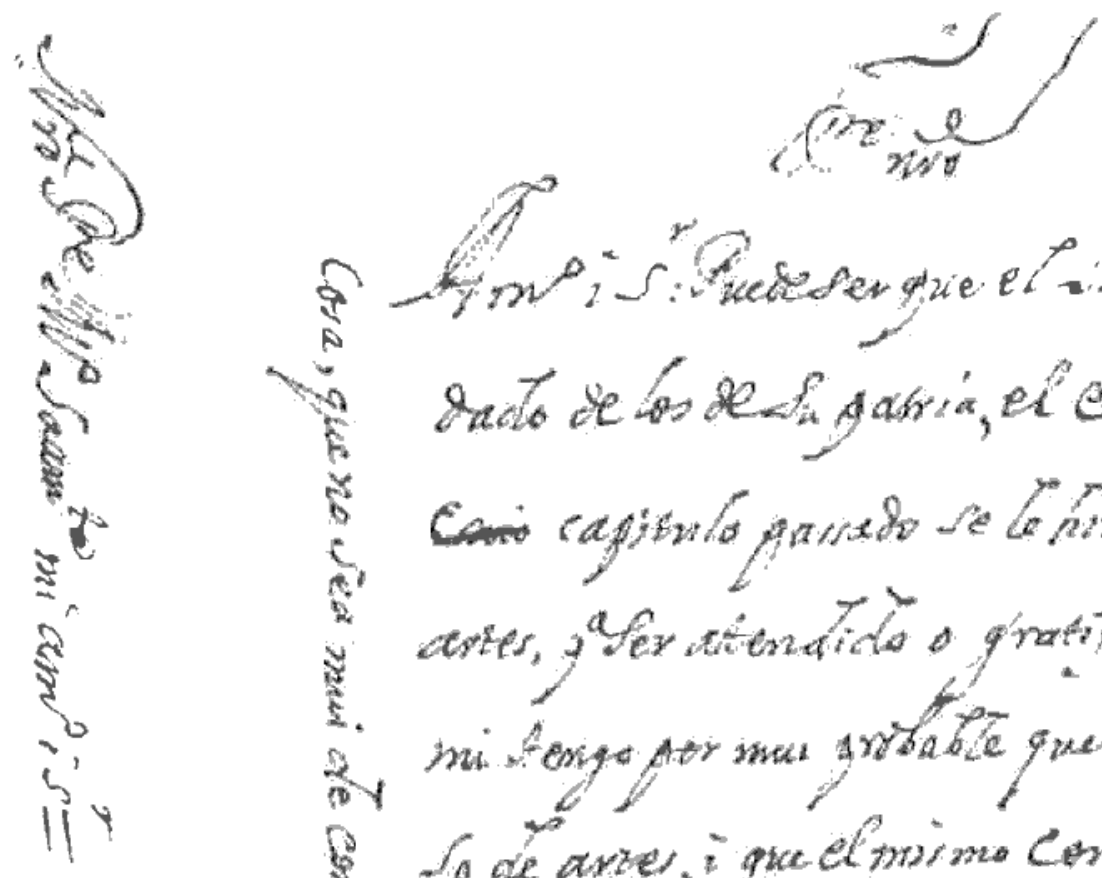

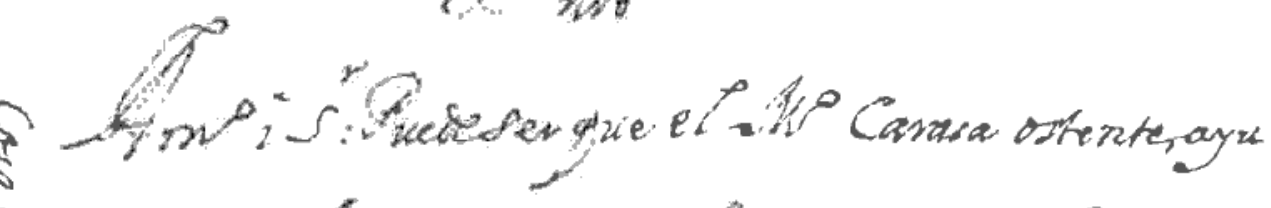

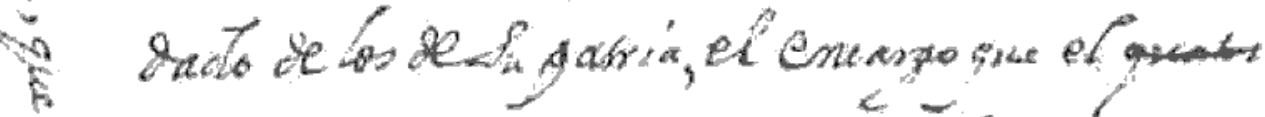

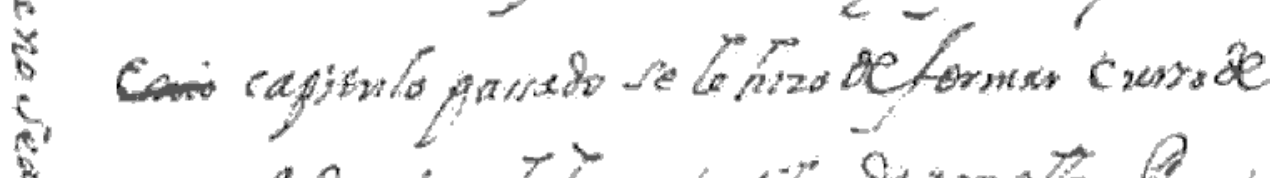

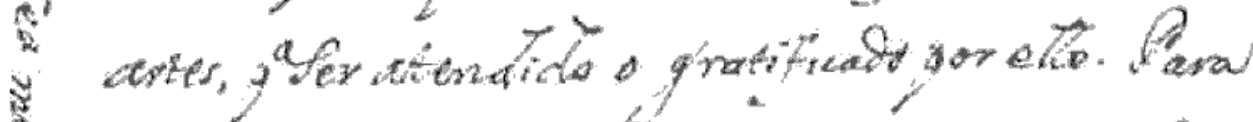

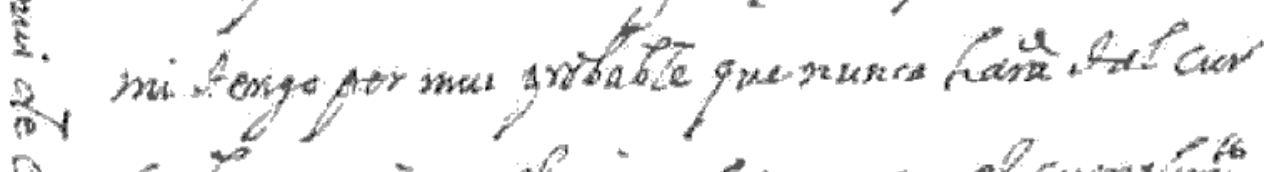

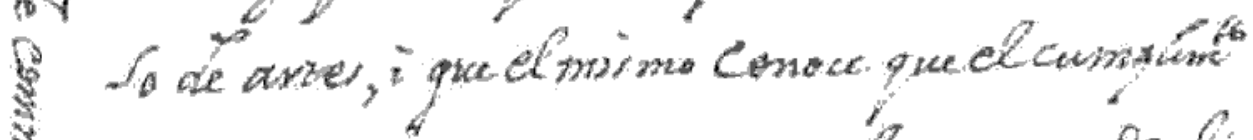

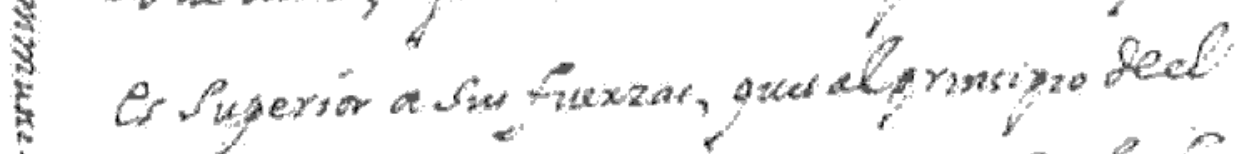

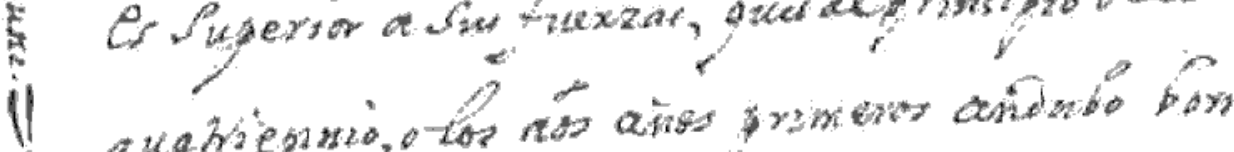

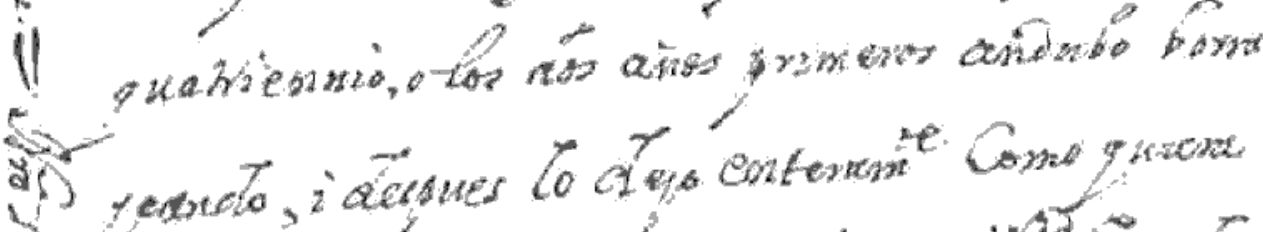

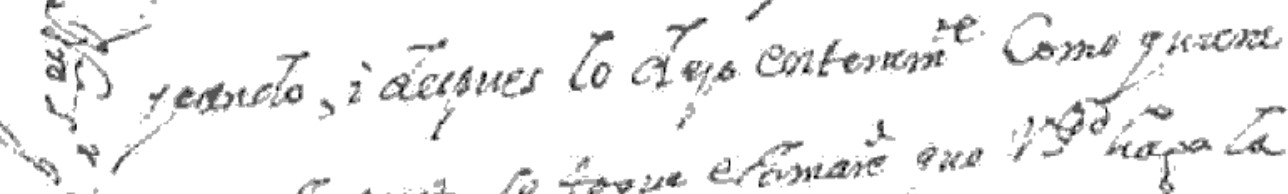

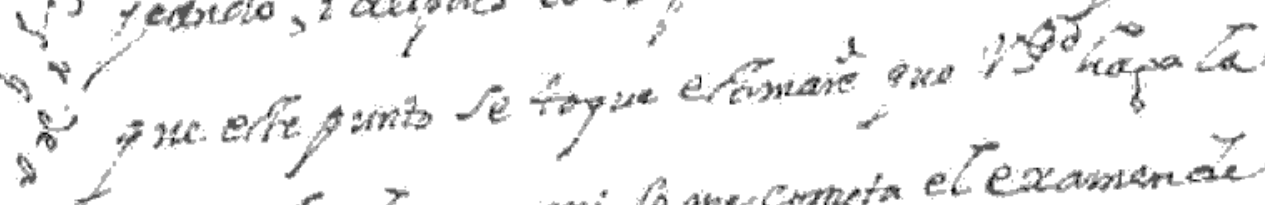

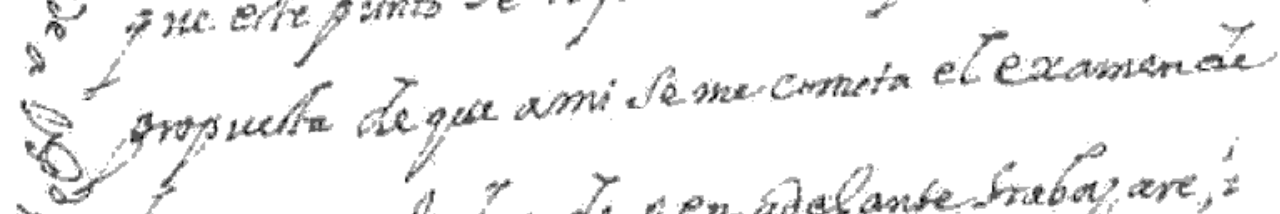

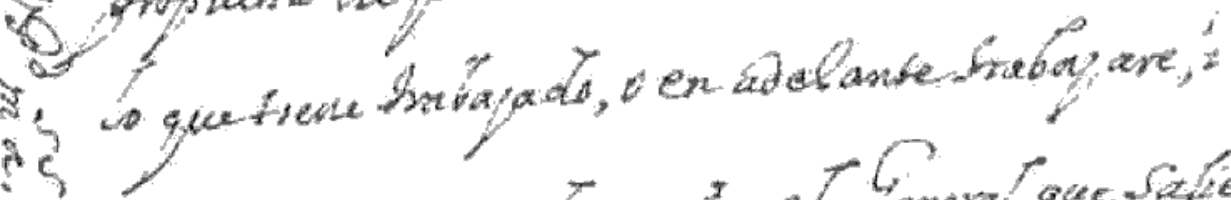

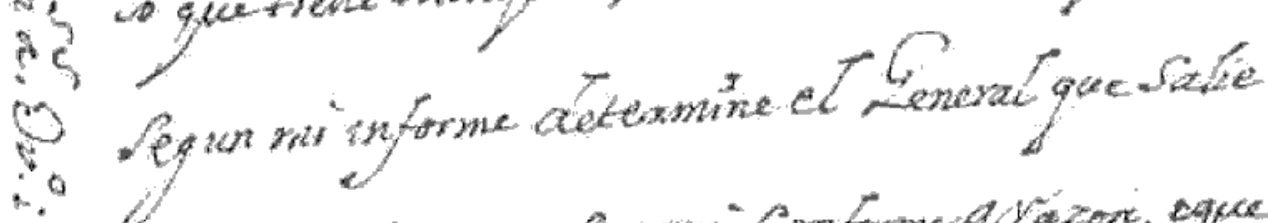

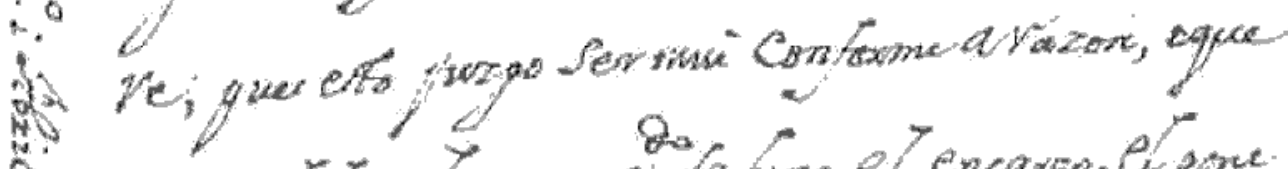

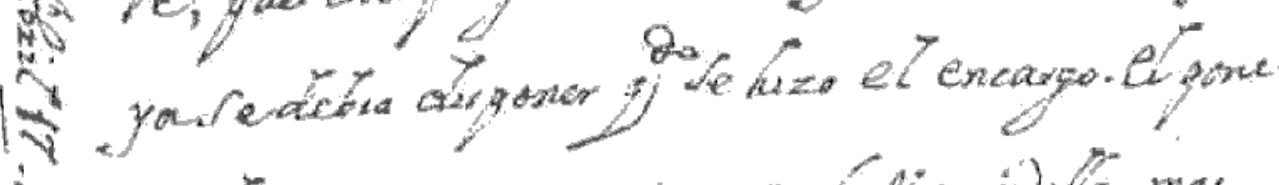

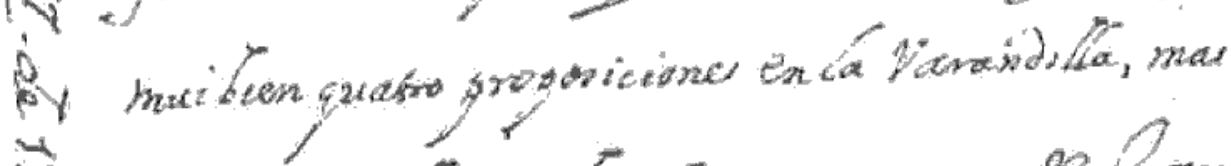
की $C^{12}$

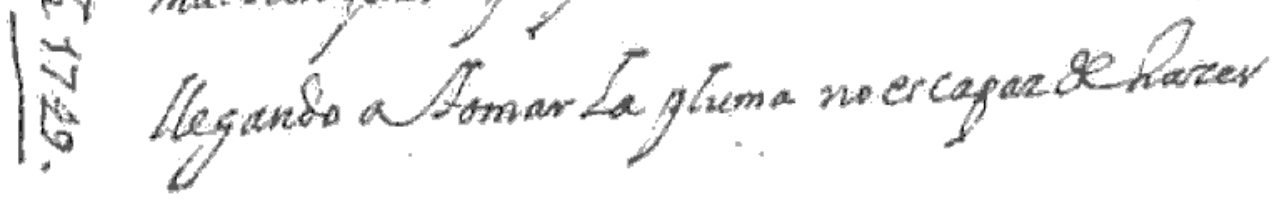


Aquí, demás de las viruelas, más infanticidas que Herodes, ay muchos tabardillos ${ }^{62}$, de los quales el uno, con grande edificaçión de todo el puteblo. llevó, no sé azia dónde, un usurero notorio i atroz, el qual con gran satisfacción dio principio a su testamento diciendo que no debía nada a nadie. Dios nos libre de el detestable viçio de la avariçia i a vuestra paternidad guarde muchos años.

Oviedo i julio 24 de 1748 .

Padre nuestro, besa la mano de vuestra paternidad su servidor i amigo de corazón,

\section{Fr. Benito Feijoo [rubricado]}

Nuestro padre maestro Sarmiento, mi amigo i señor.

1749, abril, 17. Oviedo

INTERÉS DE FEIJOO EN QUE LA ENSEŃANZA SEA E.JERCIDA POR INDIVIDUOS APTOS.

AMS, carp. C 1, núm. 14. Original autógrafa.

Cita: G. Marafíón, o. c., 37, nota 2.

Padre nuestro, amigo i señor: Puede ser que el maestro Carasa ostente, ayudado de los de su patria, el encargo que el eapitulo passado se le hizo de formar curso de artes, para ser atendido o gratificado por ello. Para mí tengo por muy probable que nunca hará tal curso de artes i que él mismo conoçe que el cumplimiento es superior a sus fuerzas, pues al principio del quatriennio o los dos años primeros andubo borrajeando i después lo dejó enteramente. Como quiera que este punto se toque, estimaré

62 Tabardillo. Vocablo hoy en desuso. El Diccionario de la lengua castellana publicado en 1739 por la Real Academia Española. lo define así: "Enfermedad peligrosa que consiste en una fiebre maligna, que arroja al exterior unas manchas pequeñas como picaduras de pulga y, a veces, granillos de diferentes colores, como morados, cetrinos, etc.) Dicho Diccionario consta de seis tomos en folio; y, como dato curioso, hemos de decir que existía un ejemplar del mismo en la librería particular del P. Maestro, el cual guardamos como oro en paño. En la portada de cada tomo está escrito de su puño y letra: Es de el $M .^{\circ}$ Feyjoo. 
que vuestra paternidad haga la propuesta de que a mí se me cometa el examen de lo que tiene trabajado o en adelante trabajare $\mathrm{i}$ según mi informe determine el general que saliere, pues esto juzgo ser mui conforme a razón i que ya se debía disponer quando se hizo el encargo. El pone mui bien quatro proposiçiones en la varandilla, mas llegando a tomar la pluma, no es capaz de hazer cosa que no sea mui de communi.

Nuestro Señor guarde a vuestra paternidad muchos años.

Oviedo i abril 17 de 1749.

Padre nuestro, besa la mano de vuestra partenidad su servidor i amigo de corazón,

\section{Fr. Benito Feijoo [rubricado]}

Nuestro padre maestro Sarmiento, mi amigo i señor. 
A P E N D I C E

DOS CARTAS DE FEIJOO AL P. VALLEJO ${ }^{63}$

1734, agosto, 28. Oviedo

AgRadece AL P. VAllejo «EL ZElo I PUNTUALIDAD» CON QUE LlevaBA EL ASUNTO ADMINistrativo DE SUS LIBROS Y LE RUEGA QUE, EN ADELANTE, SE CUIDE TAMBIÉN DE La ENCUADERNACIón DE LOS Mismos.

AMS, carp. C 1, núm. 15. Original autógrafa.

Pub., en parte: G. Marañón, o. c., 138, nota 1 .

Amigo i compañero: Los repetidos testimonios que tengo (el último i más concluyente el de nuestro padre chronista ${ }^{64}$ de el zelo i puntualidad con que manejas mis intereses en el despacho de mis libros, assí como me hazen indispensable el rendirte mui cordiales agradeçimientos por esta fineza,

63 Era conventual de San Martín de Madrid, donde residía también el P. Martín Sarmiento, y ejercía el oficio de predicador. El P. Feijoo le había confiado el manejo y administración del producto que le daba la venta de sus libros. Y, a partir de 1734. según se desprende de la primera de estas dos cartas, se le confía el cuidar también de la encuadernación de los mismos libros. En la carta n. 11 al P. Sarmiento, transerita más arriba, le Ilama Feijoo “el hidalguísimo Vallejo» y en la que figura con el $\mathrm{n} .^{\circ} 13$ al mismo Sarmiento (que le habia comunicado su fallecimiento), escribe: «La muerte de el amigo Vallejo me es mui sensible, porque cierto le amaba yo tiernamente por su bondad i honrradez).

64 El P. Martín Sarmiento, cronista oficial de la congregación vallisoletana. 
alientan al mismo passo mi confianza para duplicarte el trabajo suplicándote cargues también con la intendençia de enquadernaçión i lo demás que estaba a quenta de nuestro padre visitador ${ }^{65}$, a quien se ha exonerado de ella por la razón o sin razón que no ignorarás. Hágome cargo de que, por falta de práctica, careçerás de la instrucción necessaria para este manejo, pero ésta suplixá la dirección de nuestro padre chronista, a cuyo dictamen te arreglarás en un todo como de sujeto que mejor que otro alguno comprehende quanto ay en la materia. Espero esta nueva demonstraçión de tu amistad, como que te sirvas de la mía con toda satisfacción en quanto pueda serte útil.

A Dios que te guarde muchos años.

De esta ${ }^{66}$ tuya. Oviedo i agosto 28 de 1734.

Tu servidor i amigo de corazón que besa tu mano,

\section{Fr. Benito Feijoo [rubricado]}

Mi padre predicador Vallejo, mi amigo i señor.

[Nota marginal:] Si quando llegue ésta tubieras de dinero hecho de los libros hasta mil i quinientos reales, entrégaselo luego a nuestro padre chronista; i lo mismo harás en adelante quando aya cantidad razonable.

1741, junio, 10. Oviedo

COMUNICA A SU CORRESPONSAL LL ENVÍo DE SEIS MIL REALES.

AMS, carp. C 1, núm. 16. Original autógrafa.

Cita: G. Marañón, o. c., 138, nota 1.

Amigo i señor: Este correo despacho contra vuestra merced una libranza de seis mil reales a favor de don Domingo Fernández Cueto, mercader

65 P. Sebastián de Vergara. Véanse las nolas 40 y 48 de las cartas núms. 4 y 7 , respectivamente, al $\mathrm{P}$. Sarmiento, reproducidas anteriormente.

66 Sobrentiéndase casa o celda. 


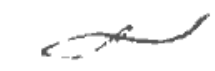

27

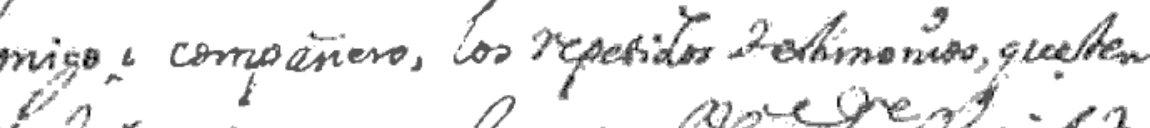

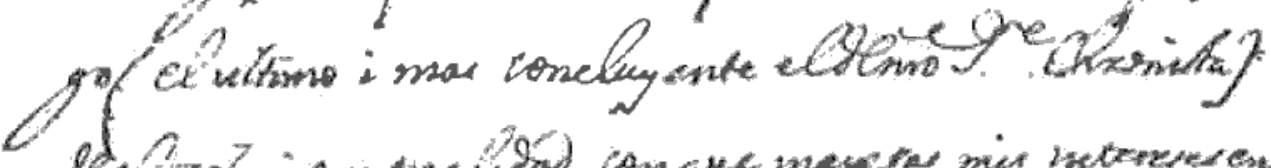

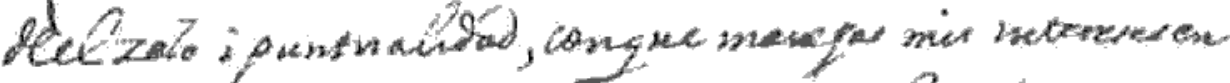

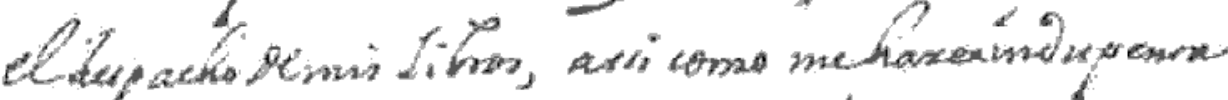
at I dos is

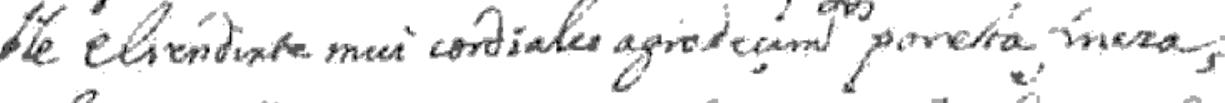

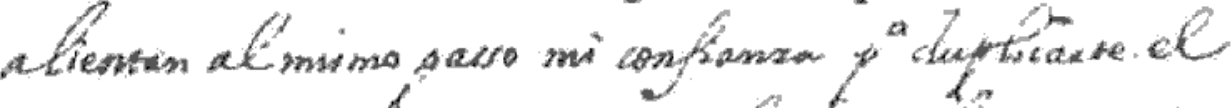

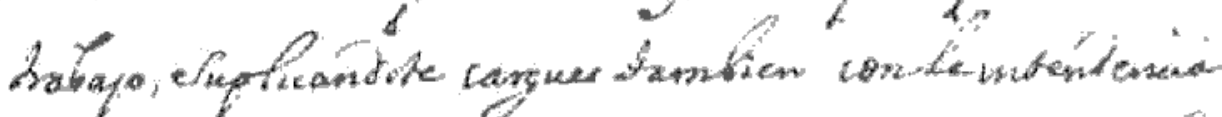

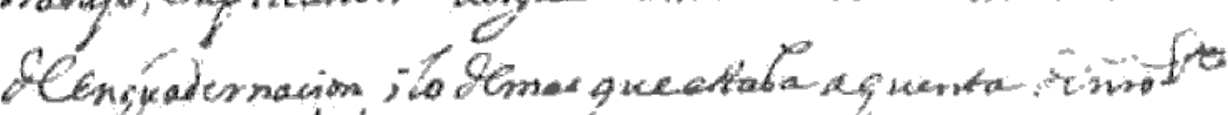

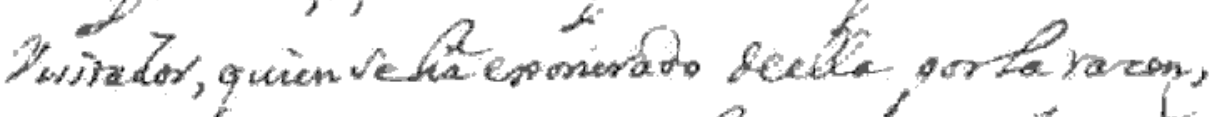

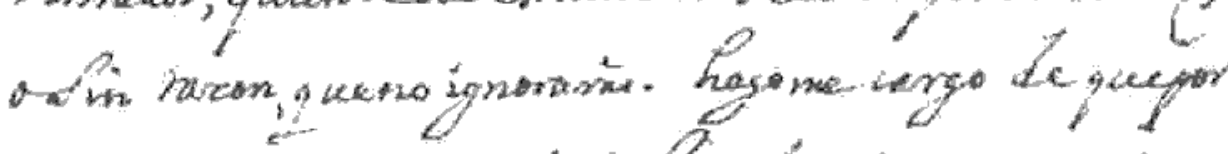

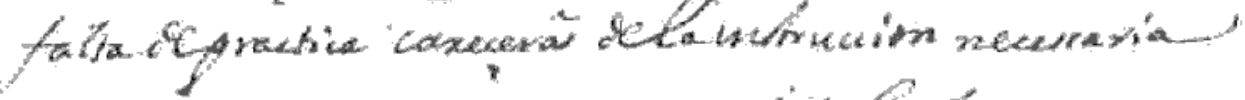

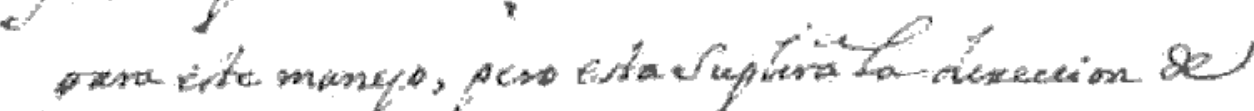

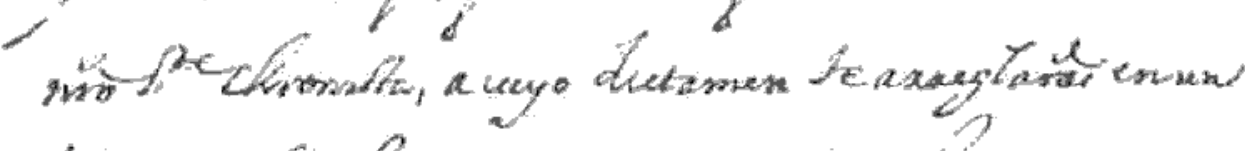

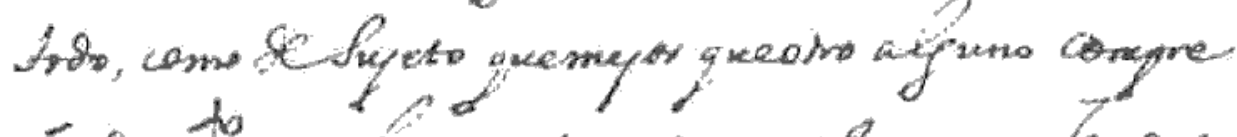

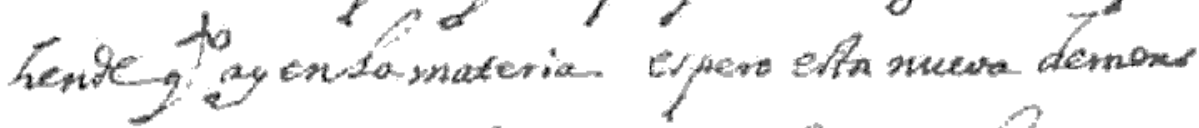

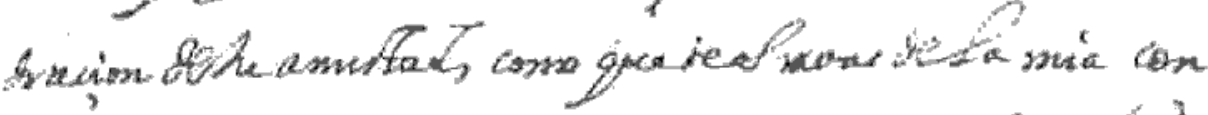

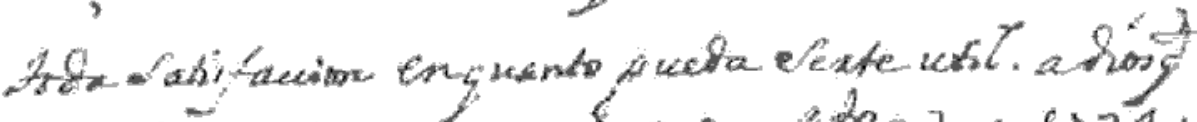

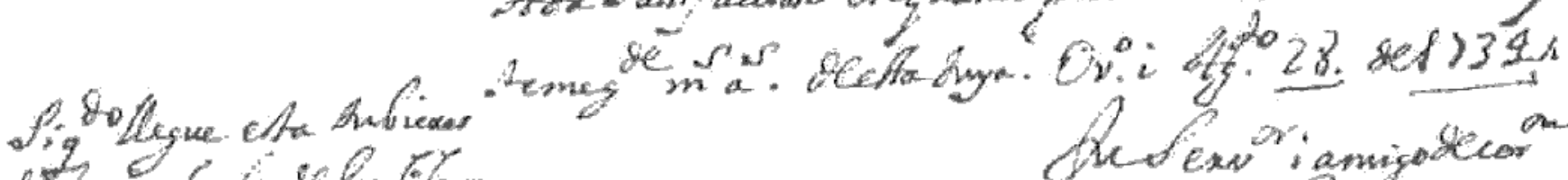

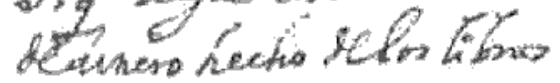

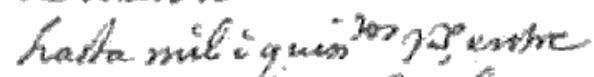

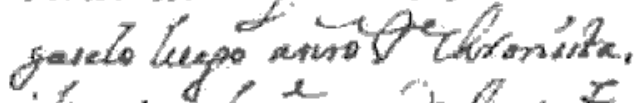
itomimo hanes unadelentale opya cansidad nazonable.

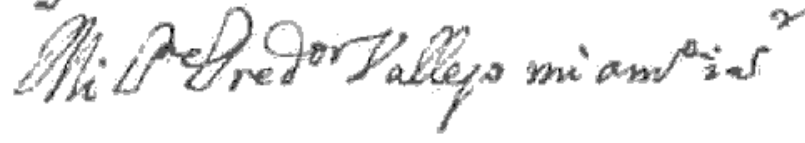


$\alpha$

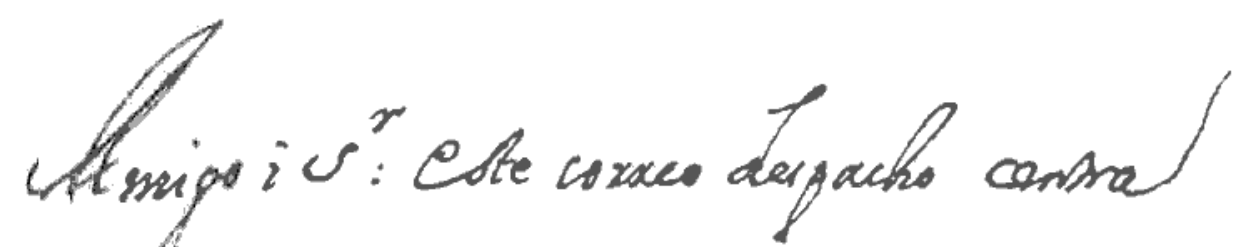

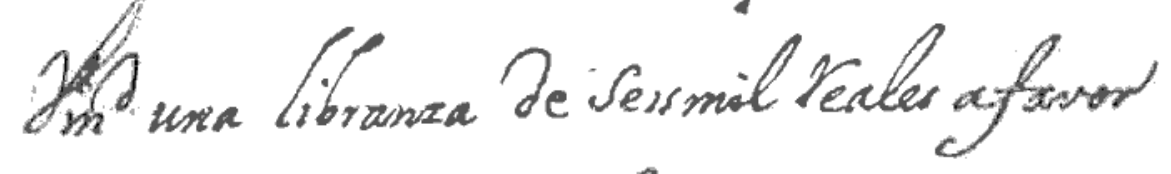

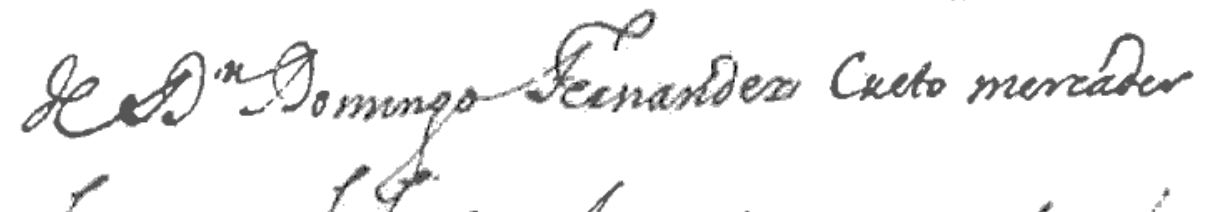
de eta ciudad. Con eta ocuion me reguira

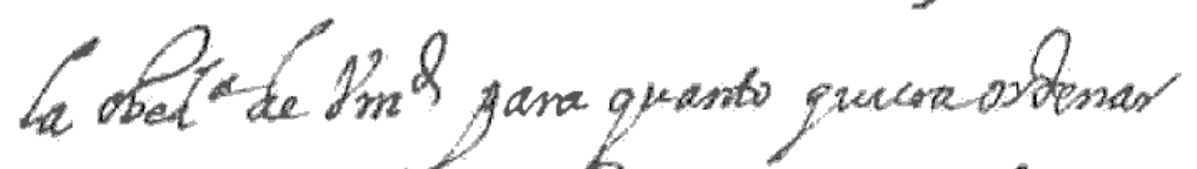

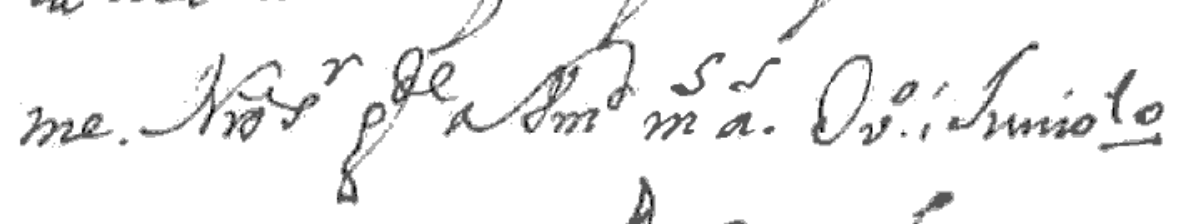
e 1721.

A.t.all arems undew ians de coror

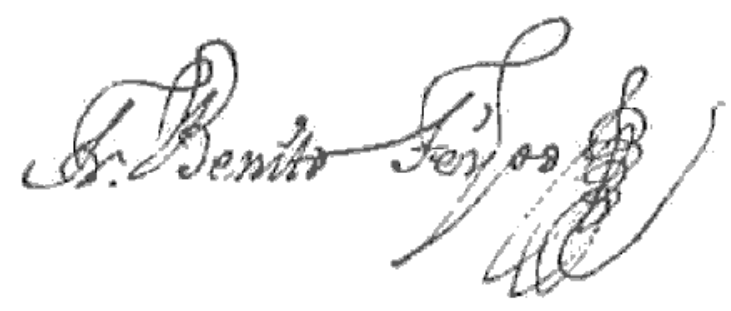

pepoorkallep niassis ${ }^{2}=$ 
de esta ciudad. Con esta ocasión me repito a la obediencia de vuestra merced para quanto quiera ordenarme.

Nuestro Señor guarde a vuestra merced muchos años.

Oviedo i junio 10 de 1741 .

Besa la mano de vuestra merced su servidor i amigo de corazón,

Fr. Benito Feijoo [rubricado]

Padre predicador Vallejo, mi amigo i señor. 